\title{
AVALIAÇÃO DE NORMAS DE IDENTIFICAÇÃO DE DEFEITOS PARA FINS DE GERÊNCIA DE PAVIMENTOS FLEXÍVEIS
}

Dissertação apresentada à Escola de Engenharia de São Carlos da Universidade de São Paulo como parte dos requisitos para obtenção do título de Mestre em Engenharia de Transportes.

Área de Concentração: Infraestrutura de Transportes.

\section{ORIENTADOR}

Prof. Dr. José Leomar Fernandes Jr. 
AUTORIZO A REPRODUÇÃO TOTAL OU PARCIAL DESTE TRABALHO, POR QUALQUER MEIO CONVENCIONAL OU ELETRÔNICO, PARA FINS DE ESTUDO E PESQUISA, DESDE QUE CITADA A FONTE.

Machado, Denise Maria Camargo

Avaliação de Normas de Identificação de Defeitos para fins de Gerência de Pavimentos Flexíveis / Denise Maria Camargo Machado; orientador José Leomar

Fernandes Jr.. São Carlos, 2013.

Dissertação (Mestrado) - Programa de Pós-Graduação em Engenharia de Transportes e Área de Concentração em Infra-Estrutura de Transporte -- Escola de Engenharia de São Carlos da Universidade de São Paulo, 2013.

1. Pavimentos Flexíveis. 2. Sistema de Gerência. 3. Avaliação. 4. Defeitos. I. Título. 


\section{FOLHA DE JULGAMENTO}

\section{Candidata: Engenheira DENISE MARIA CAMARGO MACHADO}

Título da dissertação: "Avaliação de normas de identificação de defeitos para fins de gerência de pavimentos flexíveis".

Data da defesa: $26 / 08 / 2013$

\section{Comissão Julgadora:}

Prof. Associado José Leomar Fernandes Júnior (Orientador) (Escola de Engenharia de São Carlos/EESC)

Profa. Dra. Suelly Helena de Araújo Barroso

(Universidade Federal do Ceará/UFC)

Profa. Dra. Eliane Viviani

(Universidade Federal de São Carlos/UFSCar)
Resultado:

AREOVADA

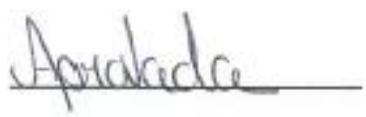

APROVAJA

Coordenador do Programa de Pós-Graduação em Engenharia de Transportes:

Prof. Associado Antônio Nélson Rodrigues da Silva

Presidente da Comissão de Pós-Graduação:

Prof. Titular Denis Vinicius Coury 

Dedico esse trabalho aos meus pais em reconhecimento ao apoio em todos os momentos de minha vida, aos meus filhos como incentivo ao seu futuro e ao meu companheiro pelo seu carinho constante. 



\section{AGRADECIMENTOS}

Agradeço a Deus pelos dons que me deu, principalmente pela capacidade de nunca me deixar abater e sempre me reconstruir.

Agradeço imensamente ao meu orientador, José Leomar, que sempre viu com otimismo as situações difíceis que surgiram ao longo destes anos de Mestrado, $e$ soube me animar e incentivar a superá-las. Em diversas ocasiões, eu chegava para nossas reuniões de trabalho um pouco confusa e cheia de dúvidas, e, aos poucos, tudo ficava claro e eu via minhas forças e minha energia renovadas para seguir em frente.

Agradeço aos meus pais, Neusa e Orlando, pelo amor e pela dedicação incondicional. Especialmente à minha mãe que me auxiliou, com seus conhecimentos de professora, na finalização deste texto. Agradeço aos meus filhos, Tiago e Yara, fonte de inspiração para que eu não desista de acrescentar algo a um mundo necessitado de boas iniciativas. Agradeço ao meu companheiro, Paulo, que me iluminou com seu otimismo nos momentos em que o desânimo surgia no caminho, e, ainda, que fez diversas sugestões em contribuição ao meu trabalho.

Agradeço aos meus irmãos, Antonio Carlos, Rogério e Ricardo, às minhas cunhadas, Valéria e Franceli, e, também, aos meus sobrinhos, Mariana, Rodrigo (meu conselheiro particular), Fernando e Lorena, todos tão presentes e intensos em me apoiar e me alegrar, inclusive durante o tempo em que me empenhei nesta Dissertação. Agradeço, ainda, à minha prima Valéria e à minha amiga Cláudia, que foram grandes incentivadoras do meu Mestrado desde o início.

Agradeço aos meus colegas de profissão, no Departamento de Estradas de Rodagem, que me auxiliaram durante todo o período em que me envolvi com a pesquisa para a Dissertação. Em especial: à Heloísa, com quem muitas vezes troquei ideias a respeito do meu trabalho, ao Alfredo e ao Gilberto, que me subsidiaram com muitos materiais de seus próprios acervos bibliográficos, ao Toyama, que me forneceu informações para o Estudo de Caso, aos colegas e chefes, Armando, Nakage, Domingos, que me apoiaram e aconselharam nas ocasiões em que precisei. 
Agradeço a todos os professores da USP, Campus de São Carlos, pelos ensinamentos passados durante o período em que estudei nesta instituição. Muitas vezes senti sincera compreensão por parte dos professores e dos funcionários, com relação às minhas dificuldades em desenvolver os trabalhos da mesma maneira com que a maioria dos alunos o fazia, pelo fato de trabalhar oito horas por dia e ter um tempo mais limitado para o curso de Mestrado.

Agradeço a todos os funcionários. Em especial ao Alexandre e à Magali, que foram sempre muito atenciosos, e à Beth e à Heloísa, que muito me auxiliaram durante todo o Mestrado, com relação à regularização de documentos, às renovações de matrículas, ao contato com professores, aos subsídios de materiais. Sem este auxílio tudo teria sido muito mais difícil para mim.

Quero agradecer à Mada, ao Diego e ao Davi pelo empréstimo de um cantinho em sua casa para que eu pudesse me hospedar, uma vez por semana, durante quase um ano. Deixo aqui meus agradecimentos sinceros a todos os queridos colegas que conviveram comigo durante meus anos agitados de Mestrado, que se tornaram amigos e companheiros por um período de tempo que será inesquecível para mim. Foram dias de convivência muito rica, alegre e aconchegante. Espero ter acrescentado à vida de cada pelo menos um pouco do muito que cada um acrescentou a minha. 
Desistir... eu já pensei seriamente nisso, mas nunca me levei realmente a sério; é que tem mais chão nos meus olhos do que o cansaço nas minhas pernas, mais esperança nos meus passos do que tristeza nos meus ombros, mais estrada no meu coração do que medo na minha cabeça.

Feliz aquele que transfere o que sabe e aprende o que ensina. 



\section{SUMÁRIO}

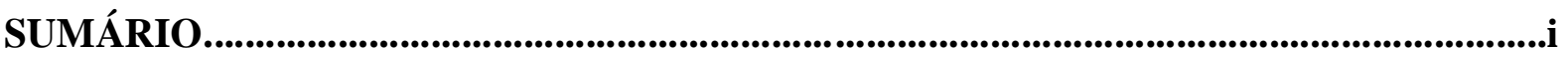

LISTA DE FIGURAS.....................................................................................................

LISTA DE TABELAS..................................................................................................................vi

LISTA DE ABREVIATURAS E SIGLAS.....................................................................vii

RESUMO.........................................................................................................................

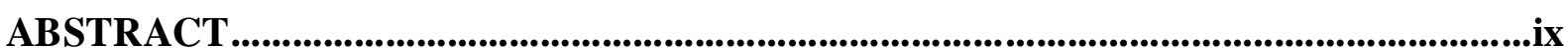

CAPÍTULO 1

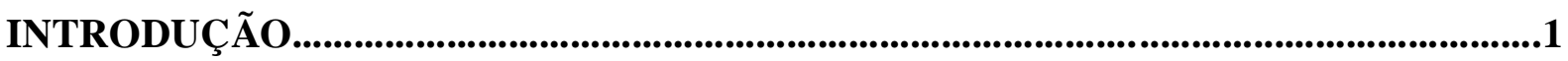

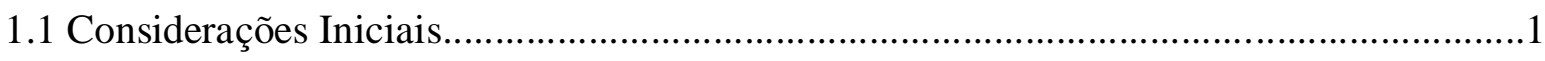

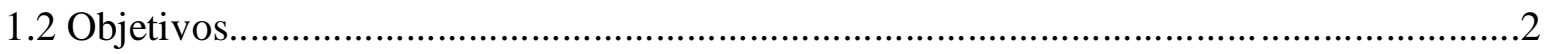

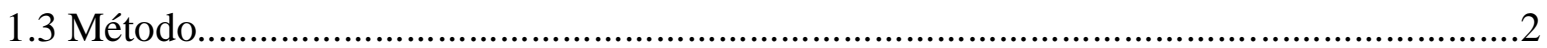

\section{CAPÍTULO 2}

DEFEITOS EM PAVIMENTOS FLEXÍVEIS.......................................................................4

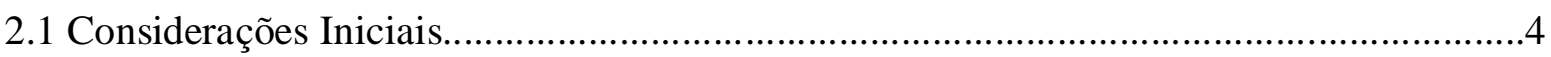

2.2 Defeitos em Pavimentos de Concreto Asfáltico - Normas dos Estados Unidos.................5

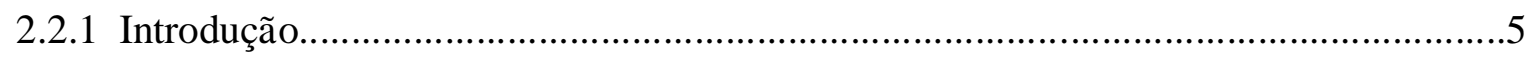

2.2.2 Trincas (ou fendas) e subdivisões.......................................................................

2.2.3 Necessidade de Remendos (ou deteriorações passíveis de remendos), Buracos.......15

2.2.4 Deformação Permanente, Corrugação (ou escorregamento)........................................17

2.2.5 Defeitos superficiais: Exsudação, Agregados Polidos, Desgaste................................19

2.2.6 Outros defeitos: Desnível entre Pista e Acostamento, Bombeamento.........................23

2.3 Defeitos em Pavimentos de Concreto Asfáltico - Normas Francesas................................25

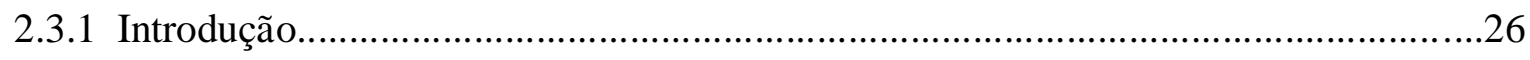

2.3.2 Degradações estruturais......................................................................................26

2.3.3 Degradações não ligadas a problemas estruturais......................................................29

2.3.4 Comparação entre os níveis de severidade segundo a França e os outros países.......32

2.4 Defeitos em Pavimentos de Concreto Asfáltico - Normas do DNIT / Brasil....................34

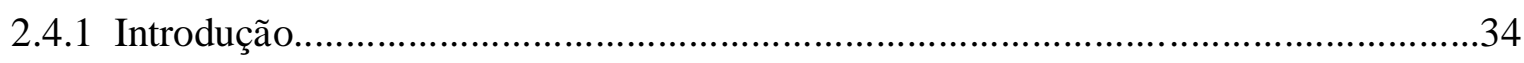

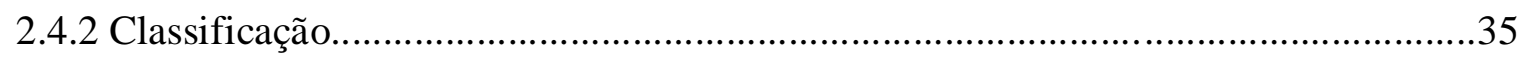

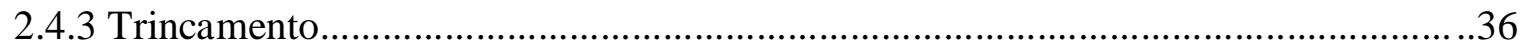

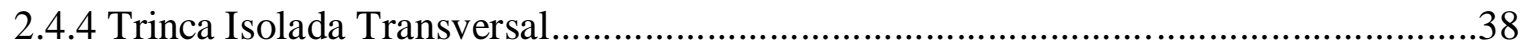

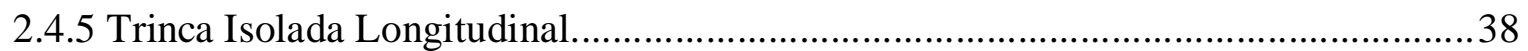




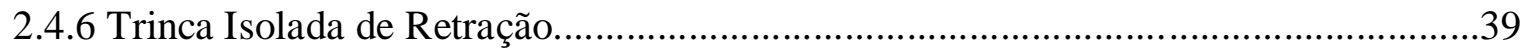

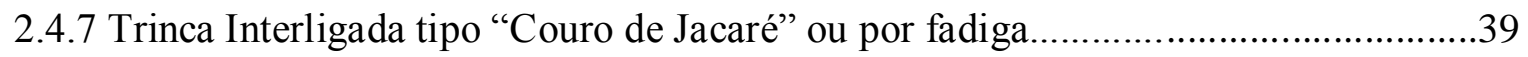

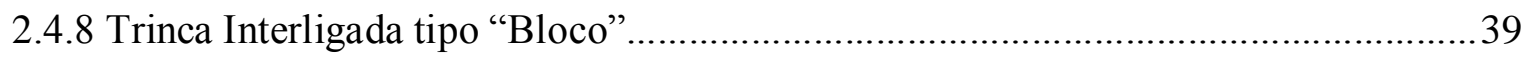

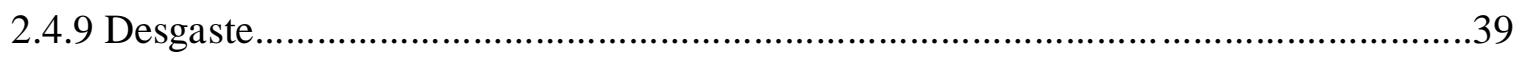

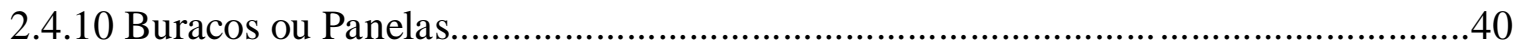

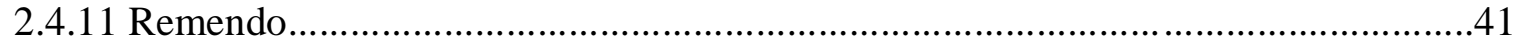

2.4.12 Afundamento ou Deformação Permanente.............................................................

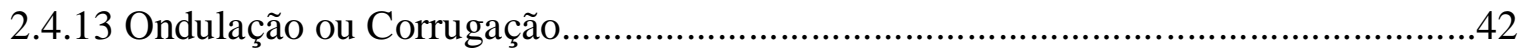

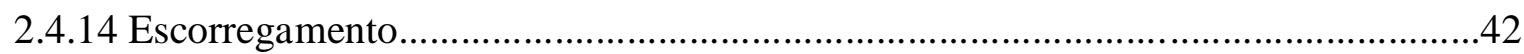

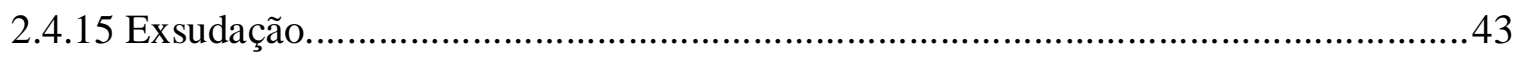

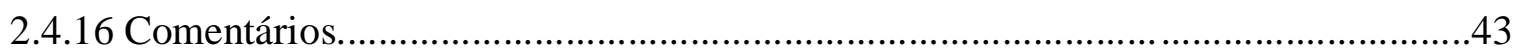

\section{CAPÍtULO 3}

AVALIAÇÕES DE DEFEITOS EM PAVIMENTOS FLEXÍVEIS...................................53

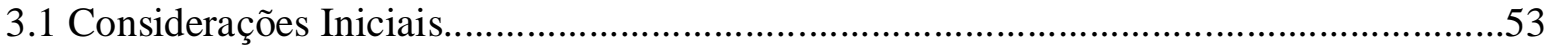

3.2 Avaliações de Pavimentos Flexíveis nos Estados Unidos.................................................54

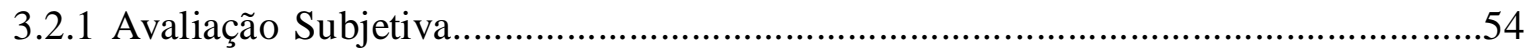

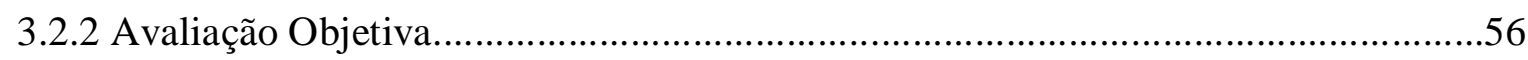

3.2.3 Aspectos das Avaliações nos EUA de relevância ao Brasil.......................................63

3.3 Avaliações de Pavimentos Flexíveis na França...............................................................63

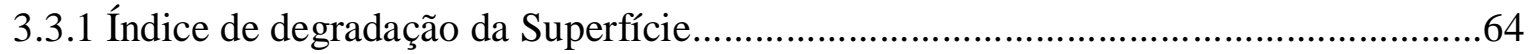

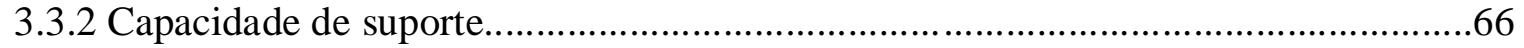

3.3.3 Aspectos de Avaliações na França de relevância ao Brasil........................................66

3.4 Avaliações de Pavimentos Flexíveis no Brasil............................................................67

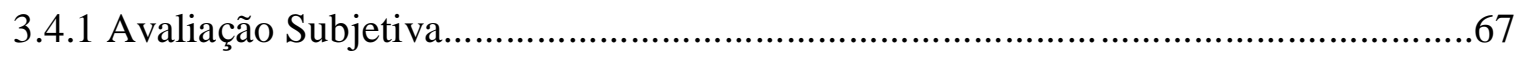

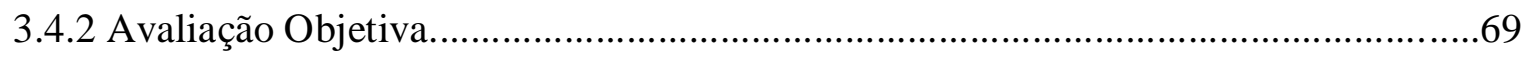

3.4.3 Levantamento Visual Contínuo.......................................................................... 71

3.4.4 Considerações sobre as Avaliações efetuadas no Brasil...........................................72

3.5 Avaliação Objetiva com Determinação do Índice de Condição do Pavimento (ICP).....73

3.6 Necessidade das Avaliações para Gerência de Pavimentos em Nível de Rede...............75

3.7 Necessidade das Avaliações para Gerência de Pavimentos em Nível de Projeto............76

3.8 Tratamento dado em Áreas Urbanas........................................................................... 77

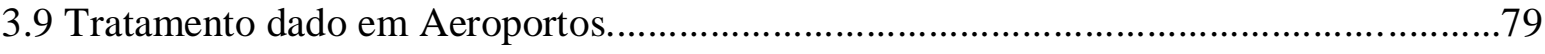

3.10 Conclusões sobre Avaliações dos Defeitos que ocorrem nos Pavimentos....................80 


\section{CAPÍTULO 4}

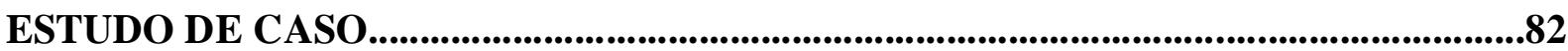

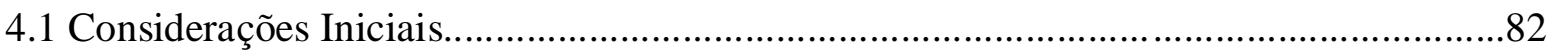

4.2 Avaliações Efetuadas pelo DER/SP com a utilização das Normas do DNER.................85

4.2.1 Avaliações Funcionais com a utilização da DNER-PRO-008/94 ..............................85

4.2.2 Levantamento Estrutural com a utilização da Viga Benkelman................................87

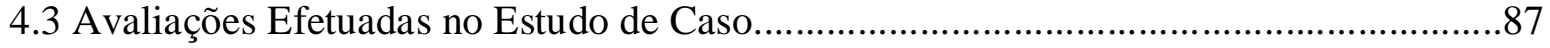

4.3.1 Levantamento Visual Contínuo (Norma DNIT 008/2003-PRO)..............................87

4.3.2 Avaliação com a utilização do conceito de Índice de Condição do Pavimento..........90

4.3.3 Avaliação Subjetiva (Norma DNIT 009/2003-PRO).............................................93

4.3.4 Avaliação Visual utilizando as Normas Francesas....................................................94

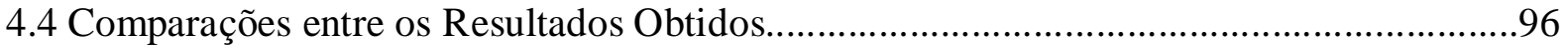

\section{CAPÍtULO 5}

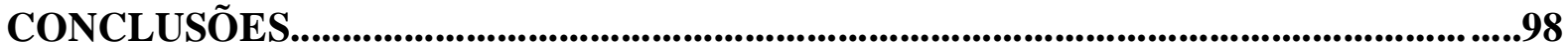

REFERÊNCIAS BIBLIOGRÁFICAS..............................................................................102

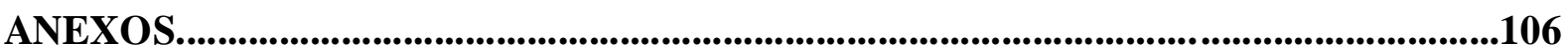





\section{LISTA DE FIGURAS}

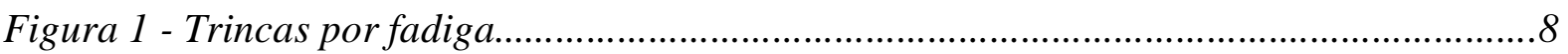

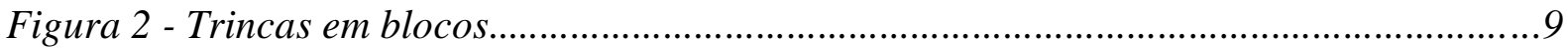

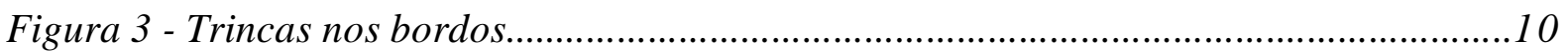

Figura 4 - Trinca longitudinal fora das trilhas de roda.........................................................1 1

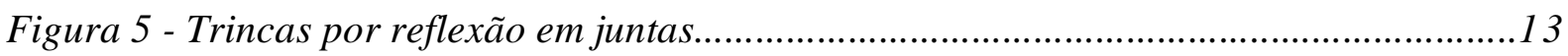

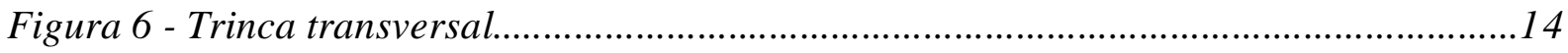

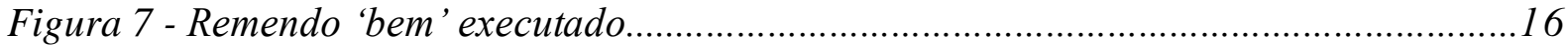

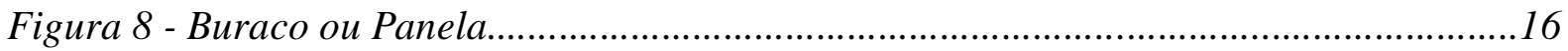

Figura 9 - Deformação permanente nas trilhas de roda ........................................................ 18

Figura 10 - Corrugação em dispositivo de acesso à rodovia ...................................................19

Figura 11 - Ocorrências de Exsudação.................................................................................20

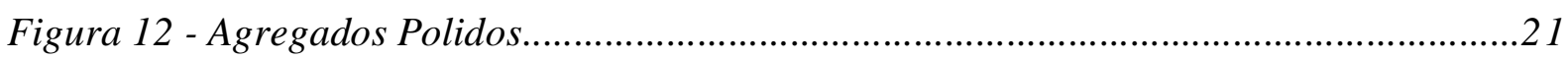

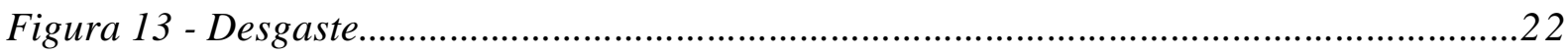

Figura 14 - Desnível entre pista de rolamento e acostamento não pavimentado.....................24

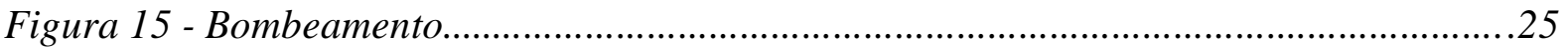

Figura 16 - Trincas por fadiga - segunda ilustração..............................................................26

Figura 17 - Deformação permanente - segunda ilustração...................................................27

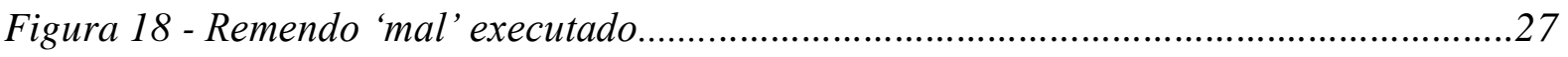

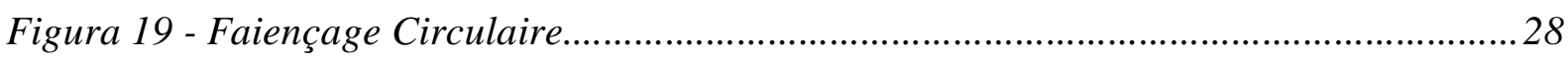

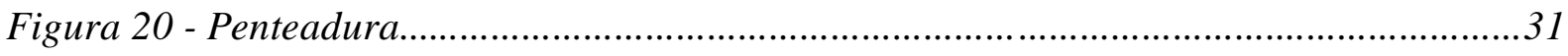

Figura 21 - Inter-relação entre desempenho dos pavimentos, estratégia de manutenção e

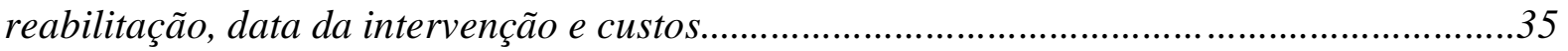

Figura 22 - Conceito de Desempenho: Variação do VSA com o Tempo ou Tráfego................55

Figura 23 - Necessidade de intervenção com base no conceito de serventia-desempenho.......55

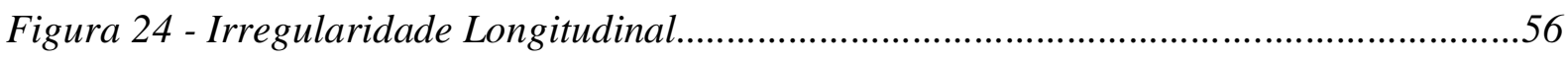

Figura 25 - Perfilômetro CHLOE, utilizado no AASHO Road Test ..........................................57

Figura 26 - Esquema do Perfilômetro CHLOE ...................................................................58

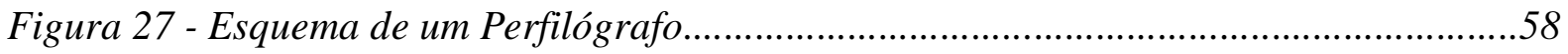

Figura 28 - Maysmeter: medidor de irregularidade do tipo resposta.....................................59

Figura 29 - Car Road Meter: equipado com acelerômetro desenvolvido pelo FHWA............59

Figura 30 - Esquema de leituras para a obtenção da bacia de deflexão..................................60

Figura 31 - Esquema da Viga Benkelman........................................................................61 
Figura 32 - Esquema de referência na viga e no caminhão...................................................62

Figura 33 - Exemplo de equipamento de medida de atrito Mu-Meter....................................63

Figura 34 - Trincas por Fadiga com erosão.......................................................................65

Figura 35 - Vista geral do trecho de Estudo de Caso - lado direito.........................................83

Figura 36 - Vista geral do trecho de Estudo de Caso - lado esquerdo......................................84

Figura 37 - Remendo de grandes proporções não sanando completamente o problema........84

Figura 38 - Detalhe de Trincas por Fadiga com abertura de alguns buracos.......................84

Figura 39 - Elevada ocorrência de veículos pesados na via utilizada para Estudo de Caso..92 


\section{LISTA DE TABELAS}

Tabela 1 - Defeitos em Pavimentos Flexíveis (FHWA, 1993; FERNADES et al., 2003)..........6

Tabela 2 - Comparação entre as classificações dos EUA, da França e do Brasil....................45

Tabela 3 - Variação dos Valores do IGGE...............................................................................72

Tabela 4 - Valores dos elementos colhidos em campo para cálculo do IGGE, correlacionados

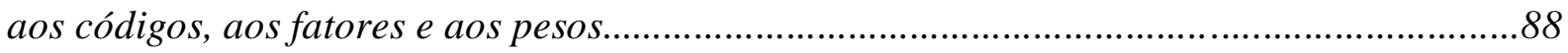

Tabela 5 - Cálculo do ICP com pontos dedutíveis atribuídos em função da severidade e extensão: Trecho I (170,300 a 171,300 lado esquerdo)......................................................92

Tabela 6 - Cálculo do ICP com pontos dedutíveis atribuídos em função da severidade e extensão: Trecho II $(172,300$ a 173,300 lado direito $)$..........................................................92

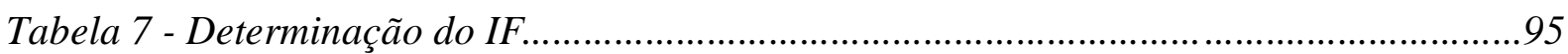

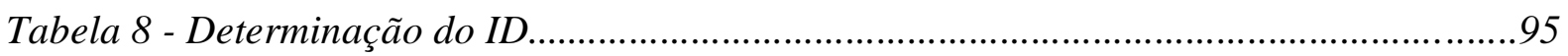

Tabela 9 - Determinação da Primeira Nota de Degradação...................................................96

Tabela 10 - Correção para Reparação.....................................................................................96 


\section{LISTA DE ABREVIATURAS E SIGLAS}

AASHO - American Association of State Highway Officials

AASHTO - American Association of State Highway and Transportation Officials

CBUQ - Concreto Betuminoso Usinado Quente

CCT - Centre Coordonnateur des Trappes - Centro Coordenador de Circulação

DER - Departamento de Estradas de Rodagem

DER/SP - Departamento de Estradas de Rodagem do Estado de São Paulo

DNER - Departamento Nacional de Estradas de Rodagem

DNIT - Departamento Nacional de Infraestrutura de Transportes

FHWA - Federal Highway Administration - Administração Rodoviária Federal

FWD - Falling Weight Deflectometer

ICP - Índice de Condição do Pavimento

ICPF - Índice de Condição de Pavimentos Flexíveis

ID - Índice de Deformação

IES - Índice do Estado de Superfície do Pavimento

IF - Índice de Fissuração

IGG - Índice de Gravidade Global

IGGE - Índice de Gravidade Global Expedito

IGI - Índice de Gravidade Individual

IS - Índice de Degradação de Superfície ou Índice Visual Global

LCPC - Laboratoire Central des Ponts et Chaussées - Laboratório Central de Pontes e Rodovias

LTPP - Long Term Pavement Performance - Desempenho do Pavimento a Longo Prazo

LVC - Levantamento Visual Contínuo

PSI - Present Serviceability Index

SETRA - Service D’Estudes Techniques des Routes et Autoroutes - Serviço de Estudos Técnicos sobre Estradas e Vias Rápidas

SHRP - Strategic Highway Research Program - Pesquisa para Desenvolvimento de um Programa de Estratégias Rodoviárias

USACE - United States Army Corps of Engineers

VDM - Volume Diário Médio

VDMA - Volume Diário Médio Anual

VSA - Valor de Serventia Atual 


\section{RESUMO}

MACHADO, D.M.C. (2013) Avaliação de Normas de Identificação de Defeitos para fins de Gerência de Pavimentos Flexíveis. 126 P. Dissertação (Mestrado) - Escola de Engenharia de São Carlos, Universidade de São Paulo.

Este trabalho analisa métodos de avaliação da condição de pavimentos asfálticos flexíveis, abordando os vários tipos de defeitos que podem surgir nos mesmos, suas causas e atividades de manutenção e reabilitação mais indicadas, em função da severidade e extensão com que se manifestam. Está inserido dentro do tema 'Gerência de Pavimentos', sendo de grande importância o conhecimento das condições dos pavimentos para a tomada de decisão quanto aos investimentos necessários para garantir o tráfego de veículos com segurança, conforto e, principalmente, economia, ou seja, com baixos custos de operação dos veículos. A avaliação dos pavimentos permite a identificação de falhas construtivas, que se manifestam precocemente, bem como acompanha o desgaste natural que sofrem todos os pavimentos, contribuindo para que as inevitáveis intervenções sejam bem selecionadas e executadas nos momentos adequados, possibilitando, assim, a melhor utilização possível dos recursos disponíveis. Neste trabalho são estudados métodos de avaliação de pavimentos utilizados no Brasil, nos Estados Unidos e na França, tanto para a gerência de pavimentos em nível de rede como em nível de projeto, para pavimentos rodoviários, urbanos e de aeroportos, com base em avaliações objetivas e subjetivas, considerando-se defeitos estruturais e não estruturais. Procurou-se fazer uma análise crítica com o intuito de contribuir para que se tenha, no Brasil, um método simples e eficiente para avaliação da condição dos pavimentos, desenvolvido com rigor acadêmico, mas de fácil utilização pelo meio técnico. Foram identificados os pontos negativos dos métodos utilizados atualmente no Brasil, buscando-se, nas normas internacionais, alternativas para a solução dos problemas existentes. Por fim, recomenda-se a revisão da Norma Brasileira, com alterações para que sua aplicação possa ser efetuada de maneira homogênea pelos diferentes técnicos que a utilizam, tornando-a mais ágil, simples e eficiente. As alterações propostas incluem: definição mais clara das Trincas, agrupamento dos defeitos Corrugação e Escorregamento, separação entre defeitos de origem estrutural e não estrutural, aplicação mais efetiva de níveis de severidade, e avaliação do pavimento com a utilização do conceito de ICP.

Palavras-Chave: Pavimentos Flexíveis, Sistema de Gerência, Avaliação, Defeitos. 


\section{ABSTRACT}

MACHADO, D.M.C. (2013) Evaluation of Pavement Distress Identification Standards for Flexible Pavement Management. 126 P. Dissertation (Master's degree) - Engineering School of Sao Carlos, University of Sao Paulo.

This study examines methods for assessing the condition of flexible pavements, addressing the various types of pavement distress, their causes and rehabilitation and maintenance activities as a function of the severity and extension of the distresses. It is housed within the theme Pavement Management, which is of great importance to the decision regarding investments necessary to ensure the traffic of vehicles with safety, comfort and, above all, economy, i.e., low vehicle operation costs. The evaluation of pavements allows the identification of construction faults, which occurs suddenly, and it also records the natural pavement wear, contributing to well selected and executed at appropriate times interventions, thus enabling a better utilization of available resources. This work analyses methods for pavement evaluation used in Brazil, in the United States and in France, for pavement management at network and project level, for road, urban and airport pavements, based on objective and subjective evaluations, considering structural and non-structural distresses. It was tried to make a critical analysis with the aim to contribute to a simple and more efficient method to evaluate pavement condition, developed with academic rigor, but easy to be used by technical personnel. The identified weaknesses in methods currently used in Brazil can be minimized by the implementation of concepts already present in international standards. Finally, it is recommended the revision of the Brazilian standard, in order to be performed in a homogeneous way by different technicians who use it, making it more agile, efficient and simple. The proposed changes include: clearer definition of Cracking, clustering of two distresses in Shoving, separation of structural and non-structural distresses, more effective application of levels of severity and extent of distress, evaluation of pavement using the PCI concept.

Keywords: Flexible Pavements, Management System, Evaluation, Distresses. 


\section{CAPÍTULO 1}

\section{INTRODUÇÃO}

\subsection{Considerações Iniciais}

O conceito de uma rodovia com boa qualidade abrange não só conforto e segurança, mas, também, a eficiência econômica, que adquire cada vez mais importância no Brasil, tendo em vista a majoritária utilização do modo rodoviário no transporte de bens e pessoas.

Assim, os defeitos encontrados nos pavimentos das rodovias comprometem a segurança e o conforto, podendo acarretar prejuízos econômicos de grande magnitude. Fazem-se necessárias constantes avaliações que sejam capazes de informar o quanto a segurança, o conforto e os custos operacionais são prejudicados pelos defeitos, como esses defeitos poderão ser reparados, os custos correspondentes e onde estão as prioridades.

Dentro dessa análise, cabe mencionar o conceito de Gerência de Pavimentos, que envolve a otimização econômica do transporte rodoviário, determinando o momento correto de serem feitas intervenções no pavimento, definindo quais serão essas intervenções e como elas serão feitas, de modo a beneficiar todos os setores da sociedade.

É possível se avaliar, tanto de maneira objetiva como subjetiva, os defeitos que os pavimentos apresentam no decorrer de sua vida útil. Entretanto, para uma efetiva avaliação desses defeitos, é necessária uma coerente classificação dos mesmos. 
As pesquisas efetuadas para elaboração deste trabalho detectaram a existência de diferentes classificações dos defeitos que surgem nos pavimentos e diferentes formas de avaliação a que estes pavimentos são submetidos. A multiplicação de classificações e avaliações não é um problema por si só, mas muitas dessas abordagens apresentam falhas teóricas e inconsistência conceitual. Fica evidente, portanto, a necessidade de uma análise crítica dos defeitos em pavimentos flexíveis que são considerados, sua definição formal, método para identificação do tipo, severidade e extensão de cada um deles especificamente.

\subsection{Objetivos}

O objetivo geral deste trabalho é propor adequações para uma melhor classificação dos defeitos que surgem em pavimentos flexíveis e, ainda, maneiras para identificar esses defeitos que possam ser utilizadas tanto para fins acadêmicos como para fins técnicos. Conjuntamente, são feitas propostas de avaliações dos defeitos existentes nos pavimentos flexíveis de maneira clara e eficiente. A intenção é atingir uma padronização de tratamento que possa ser aplicado a quaisquer circunstâncias.

\subsection{Método}

Para ser alcançado o objetivo de proposição de adequações para uma classificação mais clara e uma avaliação mais simples e eficiente dos defeitos que ocorrem em pavimentos asfálticos, são descritos estes defeitos e são analisadas as normas para avaliações dos mesmos adotadas nos Estados Unidos, na França e no Brasil.

São apontadas algumas incoerências que podem, em alguns casos, prejudicar a Gerência de Pavimentos no Brasil. 
Apresenta-se um Estudo de Caso, com avaliações funcionais e estruturais efetuadas em uma rodovia da malha estadual (DER/SP - Departamento de Estradas de Rodagem do Estado de São Paulo). Comparam-se os dados obtidos mediante avaliações rotineiras efetuadas pelos órgãos públicos que administram a malha rodoviária com os dados obtidos mediante avaliações sugeridas neste trabalho.

Ao final, são feitas sugestões para que as normas brasileiras possam agilizar melhor o atendimento às necessidades brasileiras no tocante à Gerência de Pavimentos.

O capítulo 2, a seguir, detalha os defeitos que ocorrem nos pavimentos, que surgem com maior frequência e que afetam mais a segurança, o conforto e a economia ao se transitar pelas rodovias do Brasil. Alguns defeitos são definidos de maneira diferenciada pelas várias normas, o que pode prejudicar a eficiência de um trabalho de identificação dos mesmos. A padronização, da maneira mais adequada possível, é um objetivo a ser alcançado para agilizar os processos de recuperação da malha viária brasileira. 


\section{CAPÍTULO 2}

\section{DEFEITOS EM PAVIMENTOS FLEXÍVEIS}

\subsection{Considerações Iniciais}

Para que se possa tratar com eficiência da recuperação dos pavimentos viários, com o objetivo de manter a boa condição de tráfego dos mesmos, é necessária a avaliação correta do que ocorre num dado segmento rodoviário.

Quando se aborda o assunto Identificação dos Defeitos existentes nos pavimentos rodoviários é necessário definir quais são aqueles que podem surgir. Cada defeito precisa ser identificado, assim como extensão e nível de severidade. Existem várias classificações, tanto nacionais como internacionais, o que muitas vezes dificulta o tratamento do assunto. Ao analisar as normas brasileiras, no caso o Manual do DNIT e as Normas do órgão que definem os defeitos e detalham como os mesmos devem ser avaliados, é possível constatar-se incoerências quanto a alguns defeitos, tornando difícil uma boa análise e um bom tratamento dos mesmos.

Neste trabalho foram feitas confrontações entre as várias abordagens do assunto efetuadas pelos órgãos técnicos norte-americanos, franceses e brasileiros.

Inicialmente, foi feito um estudo da abordagem feita pela FHWA (Federal Highway Administration) dentro do programa LTPP (Long Term Pavement Performance) do SHRP (Strategic Highway Research Program), que foi desenvolvido nos EUA, especificamente voltado para trabalhar essas dificuldades de tratamento do gerenciamento dos defeitos que surgem nos pavimentos rodoviários. Foi possível avaliar que, no Manual de Identificação de Defeitos, utilizado no SHRP, encontra-se uma classificação bastante objetiva desses defeitos. 
Também foi efetuada outra análise, baseada nas normas francesas, que tratam os defeitos com uma diferenciação entre aqueles 'originados por problemas estruturais' e aqueles 'originados por problemas outros que não estruturais'. Essa divisão poderá ser importante para tomada de decisão sobre 'qual tipo de reabilitação deve ser efetuado em uma rodovia', pelo fato de constatar melhor 'o que originou o defeito'.

Finalmente, foi feita uma análise, de modo crítico, do tratamento dado ao assunto pelas normas brasileiras, regulamentadas pelo DNIT. A intenção dessa análise foi propor algumas alterações com a finalidade de agilizar a implementação da Gerência de Pavimentos no Brasil.

\subsection{Defeitos em Pavimentos de Concreto Asfáltico - Normas dos Estados Unidos}

De acordo com o manual elaborado pela FHWA, nos EUA, o 'Distress Identification Manual' para o LTPP dentro do SHRP, os defeitos são subdivididos em Trincas, Remendos e Buracos (ou Panelas), Deformação Superficial e Corrugação (ou Escorregamento), Defeitos Superficiais e Outros Defeitos. Na sequência deste trabalho, cada defeito é detalhado de acordo com o manual, com acréscimo de algumas considerações do trabalho da Universidade de São Paulo, do ano de 2003, devidamente citada na bibliografia anexa, denominada "Defeitos e Atividades de Manutenção e Reabilitação em Pavimentos Asfálticos". Também foram introduzidas algumas indicações de como dimensionar os defeitos e como classificar os seus níveis de severidade de acordo com uma das bibliografias anexas, o "Modern Pavement Management", que também trata da Gerência de Pavimentos.

\subsection{1 - Introdução}

Inicialmente, o programa SHRP, iniciado em 1987, foi planejado para desenvolver um trabalho durante cinco anos. Entretanto, os objetivos a serem atingidos para o LTPP acabaram levando a um prazo adicional de quinze anos. E, em 2007, foi prorrogado por mais vinte anos. 
Ao se abordar cada defeito que ocorre no pavimento, faz-se essencial a definição do nível de severidade e o dimensionamento do mesmo: extensão em metros ou metros quadrados, ou quantidade. Também está detalhada a maneira como se entende que cada defeito deverá ser reparado.

A relação dos defeitos em pavimentos utilizada no SHRP (FHWA, 1993), bem como a sua tradução e adaptação para o Brasil (FERNANDES JR. et al., 2003), são apresentadas na Tabela 1 .

Tabela 1 - Defeitos em Pavimentos Flexíveis

\section{Cracking (trincas)}

1. Fatigue Cracking (trincas por fadiga)

2. Block Cracking (trincas em bloco)

3. Edge Cracking (trincas nos bordos laterais)

4a. Wheel Path Longitudinal Cracking (trincas longitudinais nas trilhas de roda)

4b. Non-Wheel Path Longitudinal Cracking (trincas longitudinais fora das trilhas de roda)

5. Reflection Cracking at Joints (trincas por reflexão em juntas)

6. Transverse Cracking (trincas transversais)

$>\quad$ Patching and Potholes (remendos e buracos)

7. Patch / Patch Deterioration (remendos)

8. Potholes (buracos)

$>\quad$ Surface Deformation (deformação superficial permanente)

9. Rutting (deformação permanente)

10. Shoving (corrugação)

$>\quad$ Surface Defects (defeitos superficiais)

11. Bleeding (exsudação)

12. Polished Aggregate (agregados polidos)

13. Raveling (desgaste)

$>\quad$ Miscellaneous Distresses (outros defeitos)

14. Lane-to-Shoulder Dropoff (desnível pista-acostamento)

15. Water Bleeding and Pumping (bombeamento) 
A seguir, encontram-se detalhados cada um dos defeitos.

\subsection{2 - Trincas (ou fendas) e subdivisões}

Esse defeito é associado a aberturas que surgem na superfície asfáltica. Em algumas bibliografias são citadas as 'fissuras' quando a abertura é perceptível a olho nu apenas à distância inferior a 1,5m e as 'trincas' propriamente ditas quando a abertura é superior à da fissura (BERNUCCI et al., 2007 e DNIT-005/2003-TER, 2003).

As trincas são classificadas em: Trincas por Fadiga, Trincas em Blocos, Trincas nos Bordos, Trincas Longitudinais, Trincas por Reflexão em Juntas, Trincas Transversais.

Esses tipos de trincas são descritos, a seguir, de acordo com FHWA (1993) e Fernandes Jr. et al. (2003).

a) As Trincas por Fadiga se apresentam como pequenos blocos irregulares, conectados, com aparência semelhante ao couro de jacaré ou crocodilo, com espaçamento inferior a $0,3 \mathrm{~m}$. Geralmente, esse tipo de defeito ocorre quando o pavimento, submetido a repetidas ou continuadas aplicações de cargas, devidas à ação do tráfego rodoviário, chega ao limite de sua capacidade. Isso também pode ocorrer devido a outros fatores: as cargas às quais o pavimento foi submetido estavam acima de sua capacidade estrutural de projeto, as camadas de pavimentos foram dimensionadas com espessuras inferiores às necessárias para o tráfego existente, a construção não foi acompanhada de um controle de qualidade adequado, as águas (chuvas) enfraqueceram a estrutura do pavimento. Normalmente as trincas ficam no alinhamento dos pneus dos veículos (principalmente dos veículos pesados), local chamado 'trilha de roda'. A Figura 1, extraída da Norma DNIT 005/2003-TER, ilustra esse defeito. 


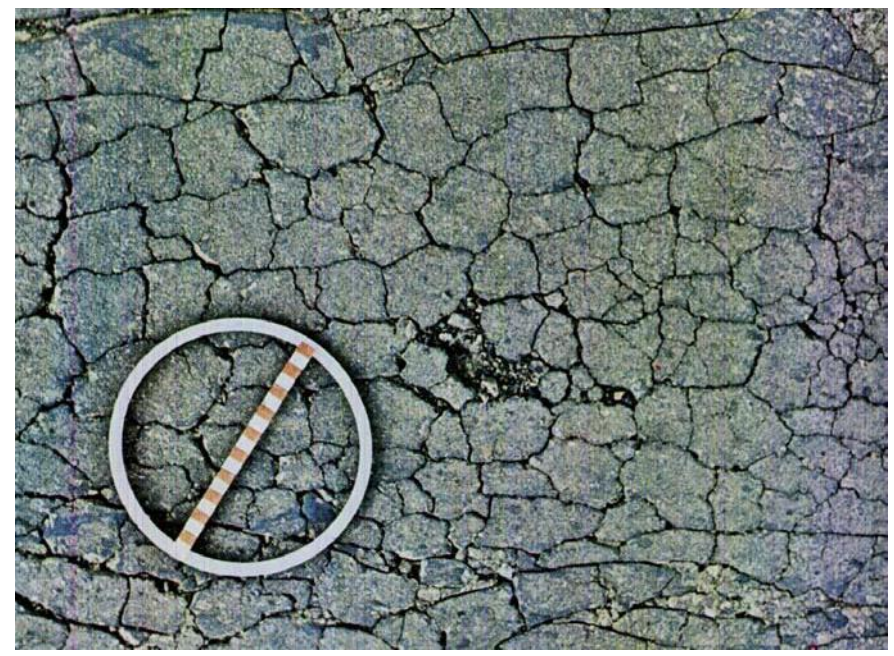

Figura 1 - Trincas por fadiga

Fonte: Norma DNIT 005/2003 - TER (2003)

A severidade deste defeito pode ser: baixa (algumas trincas, desconectadas ou levemente conectadas, sem bombeamentos e sem erosão nos bordos), moderada (há um número expressivo de conexões, formando um padrão mais definido, pode haver algum desgaste e selamento das mesmas, e, ainda, alguma erosão nos bordos, não há bombeamentos), alta (o padrão das trincas é evidente, existe selamento e desgaste acentuado, também aparecem erosões acentuadas nos bordos e pedaços são retirados com a ação do tráfego, existe bombeamento).

A medição das trincas por fadiga deve ser feita verificando-se a área de ocorrência de cada nível de severidade (baixa, moderada ou alta). Repara-se com tratamento superficial ou lama asfáltica (temporário), ou remendo (permanente). Em alguns casos, pode ser necessário o recapeamento ou a reconstrução total do pavimento.

b) As Trincas em Blocos ficam dispostas em formatos aproximados de retângulos conectados (0,1 a 10 metros quadrados de área). Muitas vezes, esse tipo de defeito é causado por contrações na mistura asfáltica além das quais ela pode suportar. Podem ser de origem térmica nas camadas superficiais, onde o revestimento pode ter sido formado a partir de misturas asfálticas com agregados finos e asfalto com baixa penetração, ou podem ser causadas por variação no teor de umidade nas camadas inferiores. 
A perda de elasticidade, que resulta no trincamento em bloco, pode ser causada por: tempo de mistura muito longo, misturas efetuadas com temperaturas acima do recomendado pelas normas de pavimentação, estocagem acima do tempo indicado pelas normas de pavimentação. A base pode ter sido tratada com cimento ou ter utilizado solos tropicais, isso também pode provocar sua contração. A Figura 2, extraída da Norma DNIT 005/2003-TER, ilustra esse tipo de defeito.

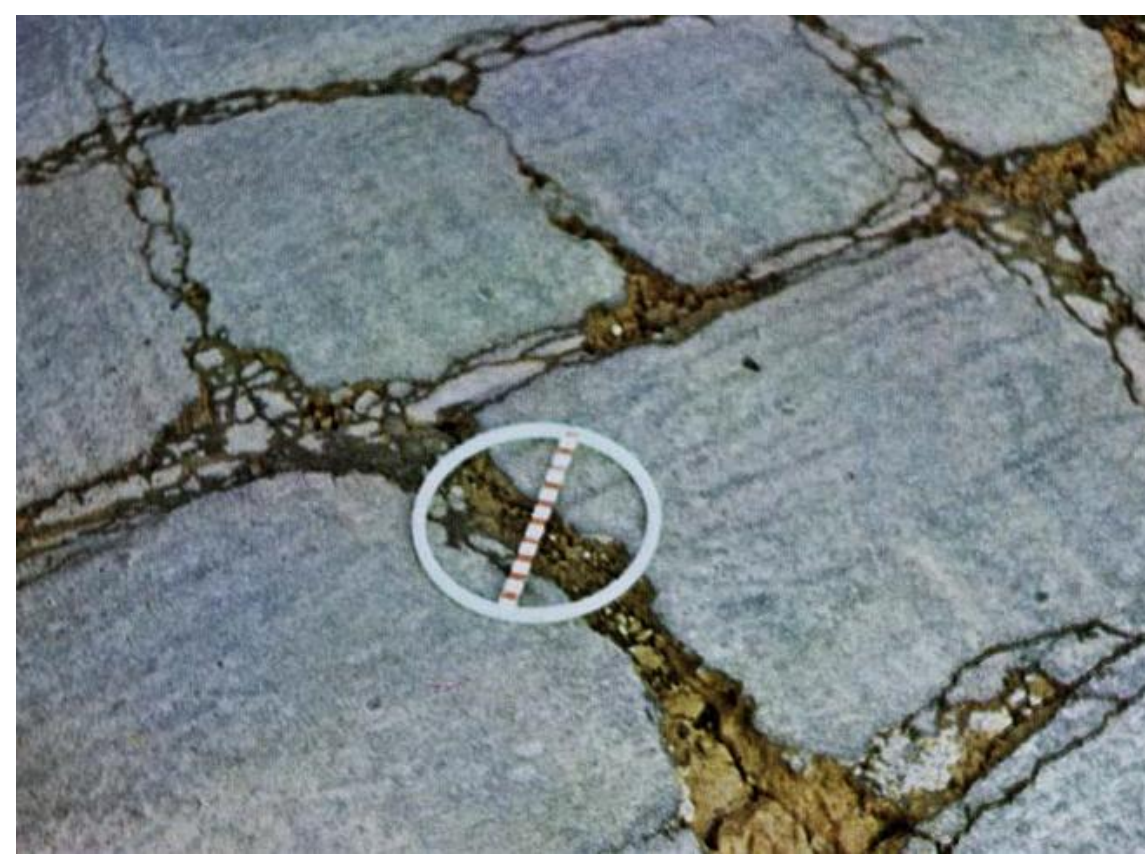

Figura 2 - Trincas em blocos

Fonte: Norma DNIT 005/2003 - TER (2003)

A severidade deste defeito pode ser: baixa (trincas com dimensão de até $6 \mathrm{~mm}$ ou trincas seladas e com dimensões indefinidas), moderada (trincas com dimensões entre 6 e $19 \mathrm{~mm}$ ou algumas trincas com menos de $19 \mathrm{~mm}$ de dimensão somadas a um número significativo de trincas com baixa severidade), alta (trincas com dimensões acima de $19 \mathrm{~mm}$ ou um número significativo de trincas com menos de $19 \mathrm{~mm}$ de dimensão somadas a um número significativo de trincas com moderada a alta severidade). A medição das trincas em bloco deve ser feita verificando-se a área de ocorrência de cada nível de severidade (baixa, moderada ou alta) e a área padrão dos blocos em cada trecho. 
Em pontos de dimensões e profundidades de trincas reduzidas pode ser utilizado material selante (emulsão asfáltica, tratamento superficial, lama asfáltica). Nos pontos de maior severidade pode ser necessário: remendo, reciclagem, recapeamento ou mesmo reconstrução do pavimento.

c) As Trincas nos Bordos ocorrem somente quando os acostamentos não são pavimentados. Surgem na borda do pavimento (no limite com o acostamento), em tamanhos irregulares e crescentes ou regulares, numa faixa de $0,60 \mathrm{~m}$ a partir da extremidade do pavimento. Aparecem como resultado de compactação insuficiente ou drenagem deficiente. A Figura 3, de origem do Arquivo do DER/SP, ilustra esse tipo de defeito na SP 338.

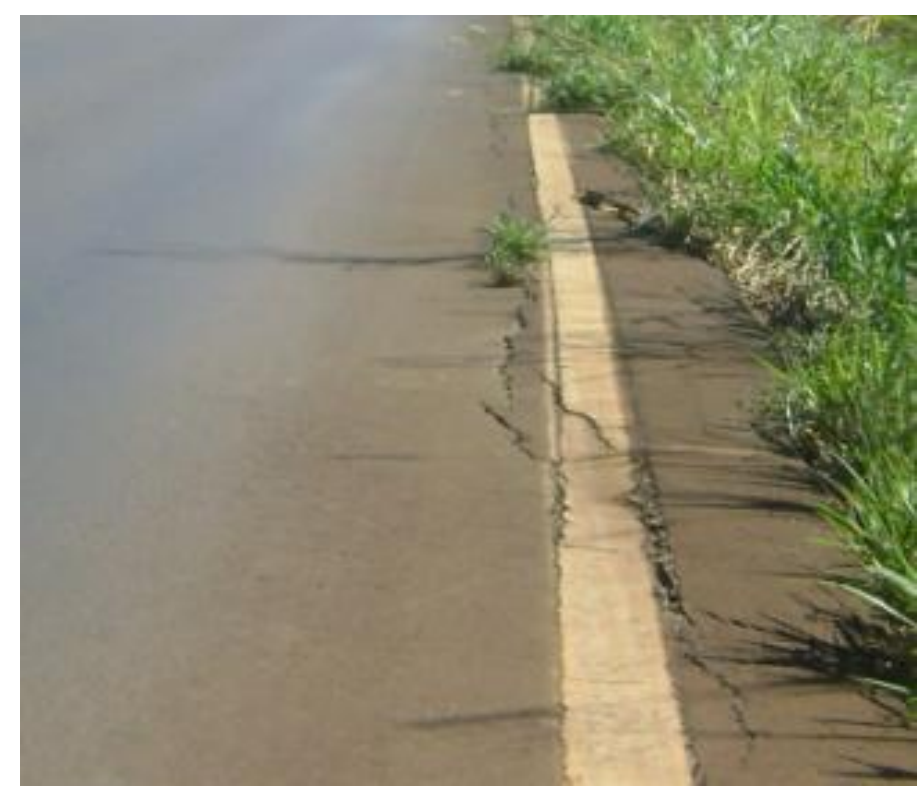

Figura 3 - Trincas nos bordos

Fonte: Arquivo do DER/SP

A severidade pode ser: baixa (trincas sem rupturas ou perda de material), moderada (com algumas rupturas e perda de material em até 10\% do comprimento do pavimento afetado), alta (trincas com rupturas e perda de material considerável em mais de $10 \%$ do comprimento do pavimento afetado). A medição das trincas nos bordos deve ser feita verificando-se a extensão (metros) do pavimento afetado, separadamente, por cada nível de severidade. 
Repara-se com selante para evitar entrada de água e enfraquecimento estrutural. No caso de drenagem deficiente, a mesma deverá ser corrigida. Em alguns casos é necessário efetuar o remendo do local danificado.

d) As Trincas Longitudinais surgem predominantemente paralelas ao eixo da rodovia. A localização é bem definida: dentro ou fora das trilhas de rodas. Essas trincas podem facilitar a penetração de água através da camada superficial do pavimento, provocando instabilidade entre as várias camadas do mesmo, e acelerar o desenvolvimento das trincas por fadiga ou o aparecimento de desgaste superficial. No caso das trincas longitudinais serem entre faixas adjacentes, fora das trilhas de roda, a causa provável dessas trincas é a compactação inadequada quando por ocasião da execução do pavimento, ou, ainda, uma compactação efetuada de maneira muito diferenciada entre cada uma das faixas. No caso das trincas longitudinais serem no limite das trilhas de roda, a causa provável é o excesso de carga aplicada, principalmente por veículos mais pesados. Também pode ser agravado por misturas com temperaturas muito elevadas aplicadas sobre base muito frágil. A Figura 4, extraída da Norma DNIT 005/2003TER, ilustra a trinca longitudinal fora das trilhas de roda.

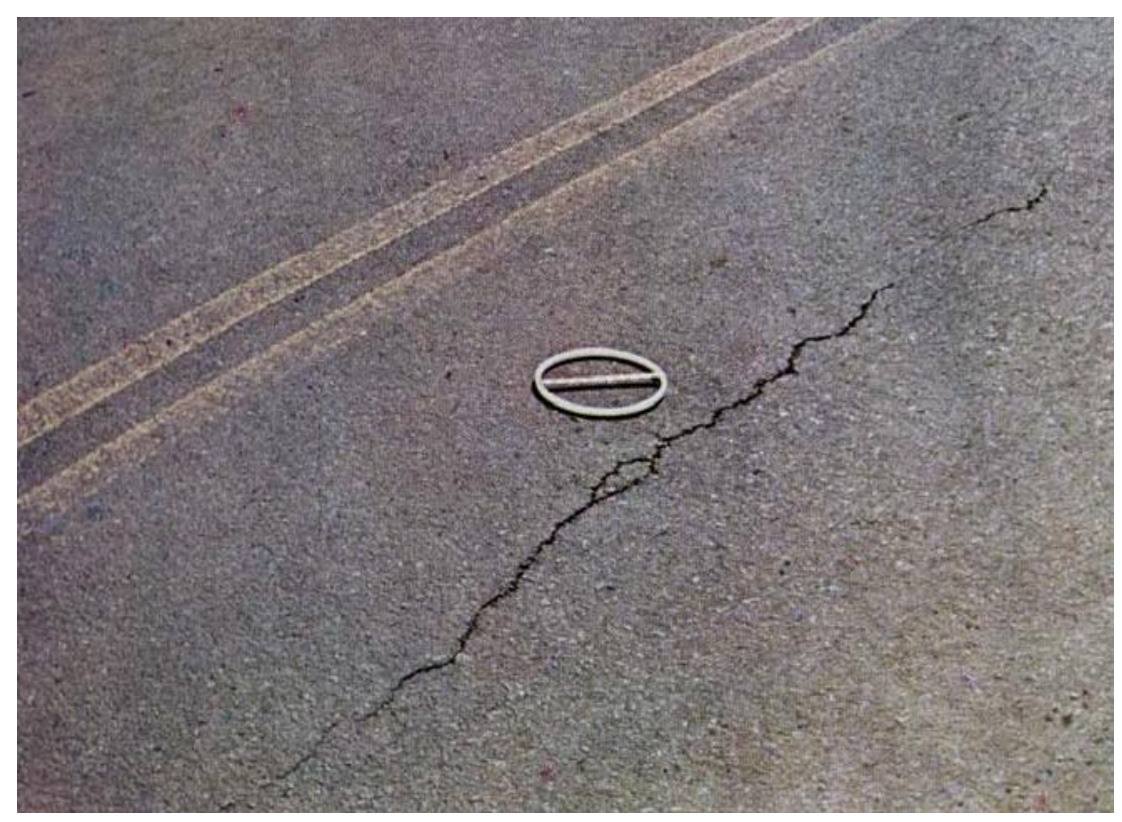

Figura 4 - Trinca longitudinal fora das trilhas de roda

Fonte: Norma DNIT 005/2003 - TER (2003) 
A severidade deste defeito pode ser: baixa (trincas com dimensão de até $6 \mathrm{~mm}$ ou trincas seladas e com dimensões indefinidas), moderada (trincas com dimensões entre 6 e $19 \mathrm{~mm}$ ou algumas trincas com menos de $19 \mathrm{~mm}$ de dimensão somadas a um número significativo de trincas com baixa severidade), alta (trincas com dimensões acima de $19 \mathrm{~mm}$ ou um número significativo de trincas com menos de $19 \mathrm{~mm}$ de dimensão somadas a um número significativo de trincas com moderada a alta severidade). A medição das trincas longitudinais, tanto dentro como fora do caminho das trilhas de roda, deve ser feita quantificando-se a extensão (metros) das mesmas com a separação por nível de severidade. Também deve ser medida a extensão de trincas seladas.

O reparo deve ser feito da seguinte maneira: as trincas menores de $3 \mathrm{~mm}$ não precisam ser reparadas, às trincas entre 3 e $20 \mathrm{~mm}$ deve ser aplicado selante, quando as trincas tiverem dimensão acima de $20 \mathrm{~mm}$ já é o caso de se efetuar remendo, recapeamento ou reconstrução do pavimento.

e) As Trincas por Reflexão em Juntas são causadas por descontinuidades nas camadas inferiores, que se propagam através do revestimento asfáltico. Esse defeito pode ocorrer em razão de trincas ou juntas nas camadas inferiores de pavimento rígido, no caso do pavimento asfáltico ter sido executado sobre pavimento de concreto, ou bases com maior rigidez, como as bases tratadas com cimento ou cal.

A severidade deste defeito pode ser: baixa (trincas com dimensão de até $6 \mathrm{~mm}$ ou trincas seladas e com dimensões indefinidas), moderada (trincas com dimensões entre 6 e $19 \mathrm{~mm}$ ou algumas trincas com menos de $19 \mathrm{~mm}$ de dimensão somadas a um número significativo de trincas com baixa severidade), alta (trincas com dimensões acima de $19 \mathrm{~mm}$ ou um número significativo de trincas com menos de $19 \mathrm{~mm}$ de dimensão somadas a um número significativo de trincas com moderada a alta severidade). A Figura 5, extraída de FHWA (1993), ilustra as trincas por reflexão em juntas. 


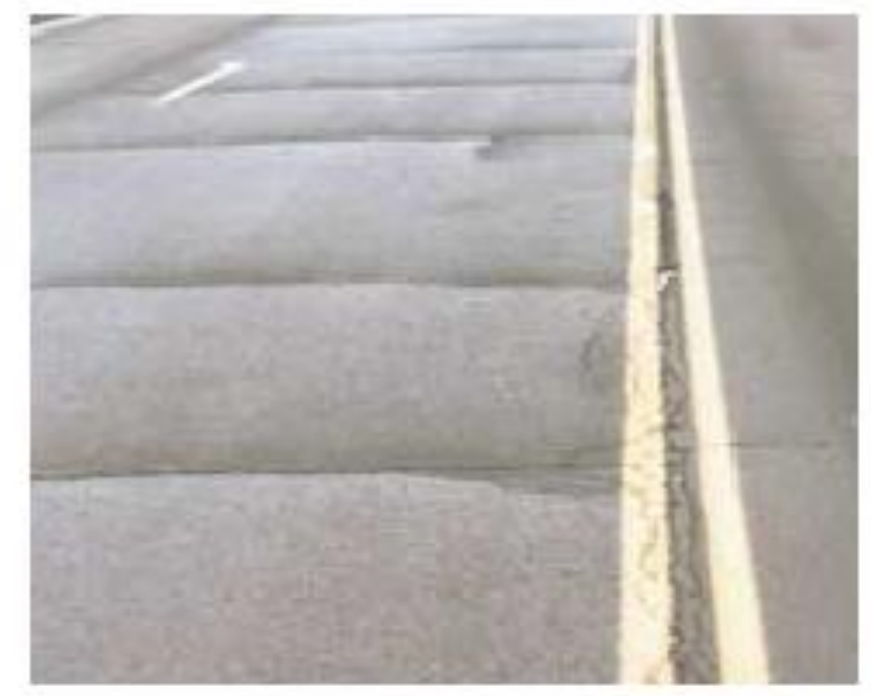

Figura 5 - Trincas por reflexão em juntas

Fonte: FHWA (1993)

A medição das trincas por reflexão em juntas é feita considerando-se o tipo de trincas que as originou. Podem ser avaliadas da mesma maneira que as trincas longitudinais ou transversais, separadamente, mensurando-se por nível de severidade. No caso das longitudinais, registra-se a extensão (dentro ou fora das trilhas de roda), no caso das transversais, registra-se a extensão e a quantidade. Também deve ser registrada a extensão de trincas seladas. As trincas por reflexão também são registradas como trincas em blocos ou trincas por fadiga, se for o caso.

Para reparar as trincas por reflexão em juntas devem ser feitos remendos e tratamento superficial ou lama asfáltica. A fim de evitar que os defeitos do pavimento antigo se propaguem no pavimento novo (reflexão), devem ser utilizadas técnicas apropriadas para tanto (geomembranas, reciclagem, outras). Nos casos da ocorrência já instalada, devem ser utilizados: remendos, recapeamento ou reconstrução do pavimento, de acordo com o tipo de trinca que 'refletiu' no pavimento superior.

f) As Trincas Transversais aparecem predominantemente perpendiculares ao eixo da rodovia. Podem ocorrer devido a contrações térmicas do revestimento e infiltração de água nas camadas inferiores. 
A severidade deste defeito pode ser: baixa (trincas com dimensão de até $6 \mathrm{~mm}$ ou trincas seladas e com dimensões indefinidas), moderada (trincas com dimensões entre 6 e $19 \mathrm{~mm}$ ou algumas trincas com menos de $19 \mathrm{~mm}$ de dimensão somadas a um número significativo de trincas com baixa severidade), alta (trincas com dimensões acima de $19 \mathrm{~mm}$ ou um número significativo de trincas com menos de $19 \mathrm{~mm}$ de dimensão somadas a um número significativo de trincas com moderada a alta severidade). A Figura 6, extraída da Norma DNIT 005/2003-TER, ilustra esse tipo de defeito.

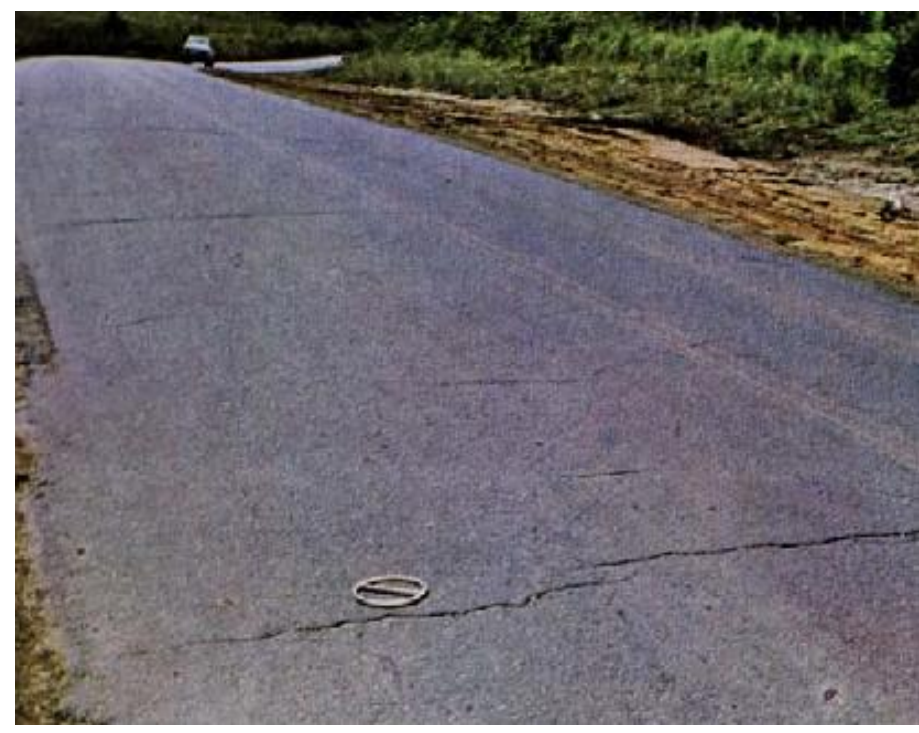

Figura 6 - Trinca transversal

Fonte: Norma DNIT 005/2003 - TER (2003)

As trincas transversais são medidas através da quantificação do número dessa ocorrência e da sua extensão (metros) para cada nível de severidade. Deverá haver mais de $10 \%$ da gravidade indicada para ser assim classificada. Também devem ser indicadas as extensões das trincas seladas em cada nível de severidade. Trincas transversais com extensão inferior a 30 cm não são registradas.

O reparo da trinca já instalada é feito com utilização de material selante em pontos de dimensões e profundidades de trincas reduzidas. Nos pontos de maior severidade pode ser necessário: remendo, reciclagem, recapeamento ou mesmo reconstrução do pavimento. No caso de infiltração de água nas camadas inferiores deverá ser corrigida a drenagem para evitar a reincidência do defeito. 


\subsection{3 - Necessidade de Remendos (ou deteriorações passíveis de remendos), Buracos}

No Manual de Defeitos utilizado nos EUA (FHWA, 1993) os remendos e os buracos são agrupados como defeitos semelhantes. O remendo é um tipo de defeito, apesar de estar relacionado a uma conservação da superfície, que se caracteriza pelo preenchimento de panelas ou de qualquer outro orifício ou depressão com massa asfáltica. Já a panela ou buraco é uma cavidade que surge no revestimento asfáltico e que pode ou não atingir camadas subjacentes (BERNUCCI et al., 2007). A seguir estão detalhados os dois tipos de defeitos, segundo FHWA (1993) e Fernandes Jr. et al. (2003).

a) O Remendo é uma porção de pavimento superficial, maior que $0.1 \mathrm{~m}^{2}$, que é removida e substituída por material aplicado sobre a construção original da via. Vários defeitos podem causar a Necessidade de Remendos.

A severidade pode ser: baixa (dimensões inferiores a $6 \mathrm{~mm}$ pouco afetando a qualidade de tráfego), moderada (dimensões entre $6 \mathrm{~mm}$ e $12 \mathrm{~mm}$ afetando moderadamente a qualidade de tráfego), alta (dimensões superiores a $12 \mathrm{~mm}$ e com bombeamento ocasional e também com grave interferência na qualidade de tráfego). Esses limites estão indicados no FHWA (1993). A severidade também pode ser medida em função dos defeitos que serão corrigidos. $\mathrm{O}$ bombeamento não é evidente nos casos de baixa e moderada severidade. Para quantificar esse defeito, é feito o registro de ocorrências e a área afetada relativa a cada nível de severidade.

O reparo é feito através de recorte e limpeza da área atingida, aplicação da camada impermeabilizante e aderente, e, posteriormente, do material de reposição. Quando o material é aplicado sem o recorte da área atingida, apenas após a limpeza, o nome dado ao reparo é 'tapa-buraco'. A Figura 7, extraída de Bernucci et al. (2007), ilustra um 'remendo bem executado'. 


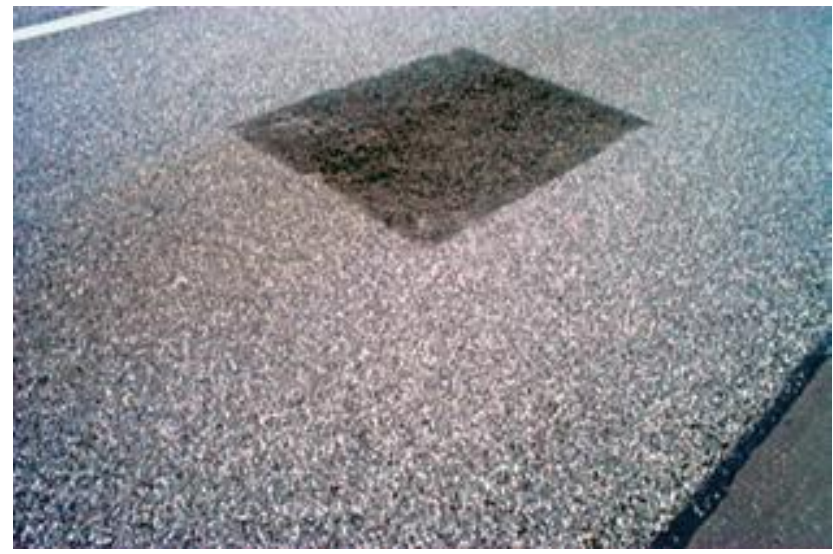

Figura 7 - Remendo 'bem’ executado

Fonte: Bernucci et al (2007)

b) Já os Buracos ou Panelas são resultantes de desintegração localizada, sob a ação do tráfego e em presença de água. Apresentam fragmentação do pavimento, após a ocorrência de trincas por fadiga ou desgaste, e remoção localizada de partes do revestimento. Ocorrem em forma de tigela, de vários tamanhos, na superfície do pavimento. É mais comum sua ocorrência em revestimentos com pouca espessura ou baixa capacidade de suporte das camadas inferiores (falha estrutural). Pode aparecer em locais com segregação de material (falta de ligante em alguns pontos) ou com problemas construtivos (drenagem inadequada). A Figura 8, extraída da Norma DNIT 005/2003-TER, ilustra esse tipo de defeito.

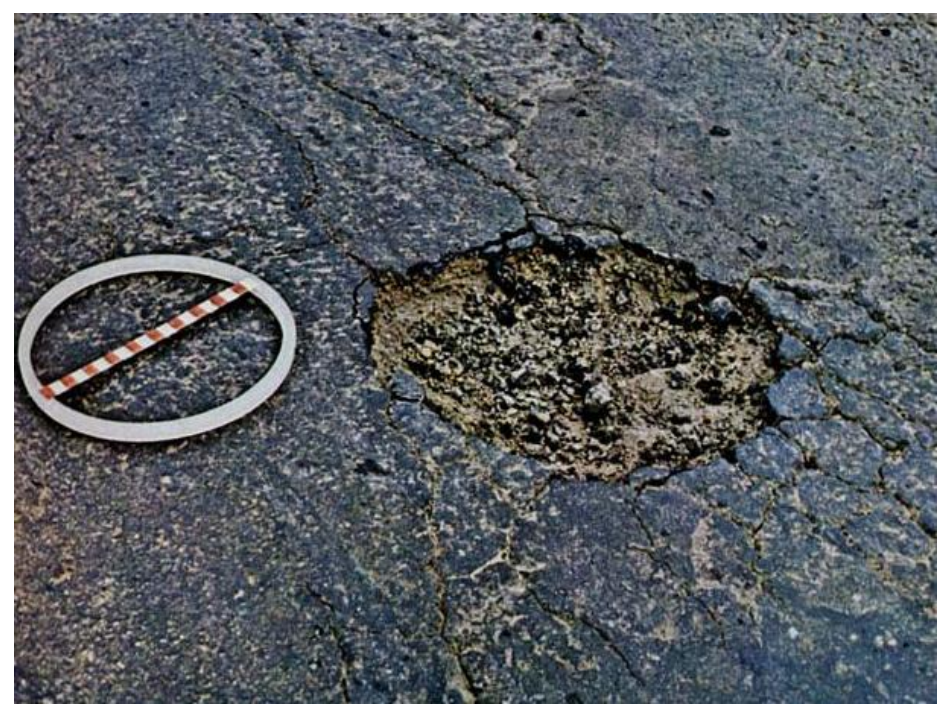

Figura 8 - Buraco ou Panela

Fonte: Norma DNIT 005/2003 - TER (2003) 
O nível de severidade pode ser: baixo (até $25 \mathrm{~mm}$ de profundidade), moderado (de 25 a $50 \mathrm{~mm}$ de profundidade), alto (acima de $50 \mathrm{~mm}$ de profundidade). Esses limites estão indicados no FHWA (1993) e apresentam coerência com a maneira de tratar esse tipo de defeito nos EUA, entretanto, para a realidade brasileira, esses valores podem sofrer algumas alterações para intervalos maiores.

Para medir esse defeito deve ser registrada a quantidade de ocorrência e a área afetada relativa a cada nível de severidade. O reparo deve ser feito com a execução do remendo, seguido de recapeamento se for o caso, dependendo do tamanho da área comprometida.

\subsection{4 - Deformação Permanente, Corrugação (ou escorregamento)}

Do mesmo modo que no item anterior, o Manual de Defeitos dos EUA (FHWA, 1993) agrupa essas ocorrências como defeitos semelhantes. Esses defeitos ocasionam depressões no pavimento e solevamentos da massa asfáltica. (BERNUCCI et al., 2007). A seguir são detalhados esses dois tipos de defeitos, conforme as bibliografias de FHWA (1993) e Fernandes Jr. et al. (2003).

a) A Deformação Permanente aparece no caminho das rodas, ou trilha de rodas. É um afundamento longitudinal que acompanha o trajeto percorrido pelas rodas dos veículos. Normalmente ocorre devido à densificação dos materiais ou à ruptura por cisalhamento. Pode advir de: dimensionamento inadequado das espessuras das várias camadas, dosagem inadequada da mistura asfáltica, compactação inadequada e posterior consolidação pela ação do tráfego, falha na drenagem. No caso da ruptura por cisalhamento, o afundamento nas trilhas de roda é acompanhado por elevação nas laterais, paralelamente ao tráfego. A Figura 9, extraída da Norma DNIT 005/2003TER, ilustra a deformação permanente nas trilhas de roda. 


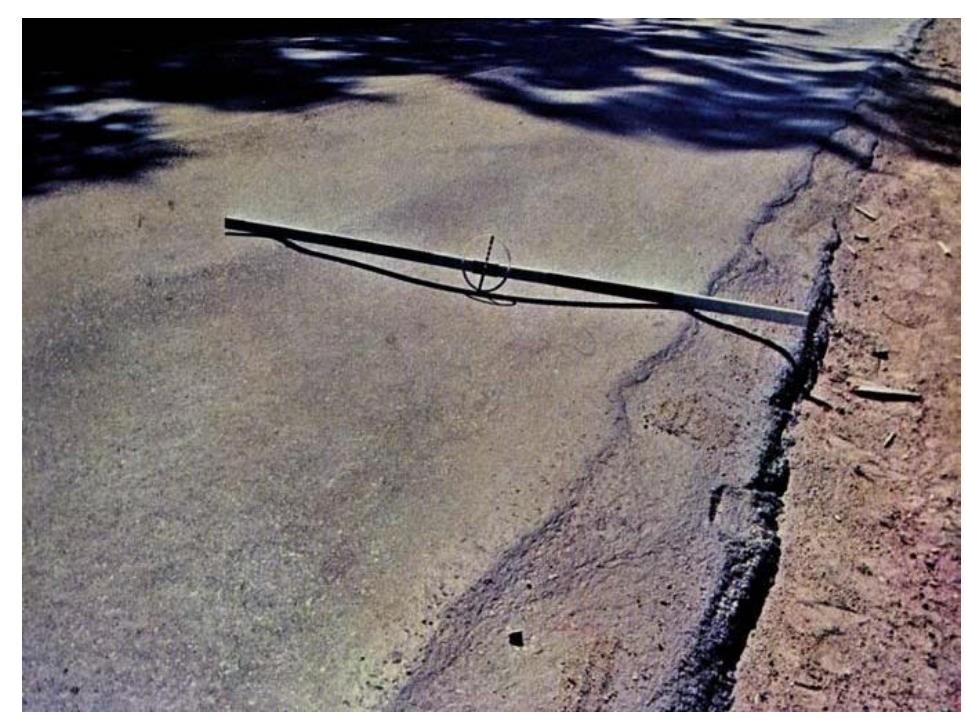

Figura 9 - Deformação Permanente nas trilhas de roda Fonte: Norma DNIT 005/2003 - TER (2003)

Os níveis de severidade podem ser: baixo (até $25 \mathrm{~mm}$ de profundidade), moderado (entre 25 e $50 \mathrm{~mm}$ de profundidade), alto (acima de $50 \mathrm{~mm}$ de profundidade). Devem ser anotadas medições do desnível ou profundidades máximas das deformações, em milímetros, com intervalo de $20 \mathrm{~m}$ (vinte metros). Esses limites estão indicados em Haas et al. (1994). O reparo deve ser efetuado com execução de reciclagem, recapeamento ou reconstrução total do pavimento.

b) A Corrugação ou Escorregamento apresenta-se como um deslocamento longitudinal do pavimento, ocasionando ondulações transversais na sua superfície. Geralmente, esse deslocamento é causado pelo movimento de 'frenagem' ou 'aceleração' dos veículos e acontece em razão de dosagem inadequada da mistura asfáltica, fraca ligação entre base e revestimento, e estrutura insuficiente. Normalmente é localizado em curvas, intersecções, aclives ou declives.

Os níveis de severidade podem ser determinados em função do quanto a qualidade do tráfego é afetada. A Figura 10, extraída de Arquivo do DER/SP, ilustra o defeito ‘corrugação' com o aparecimento de alguns ‘buracos' e problemas de drenagem. 


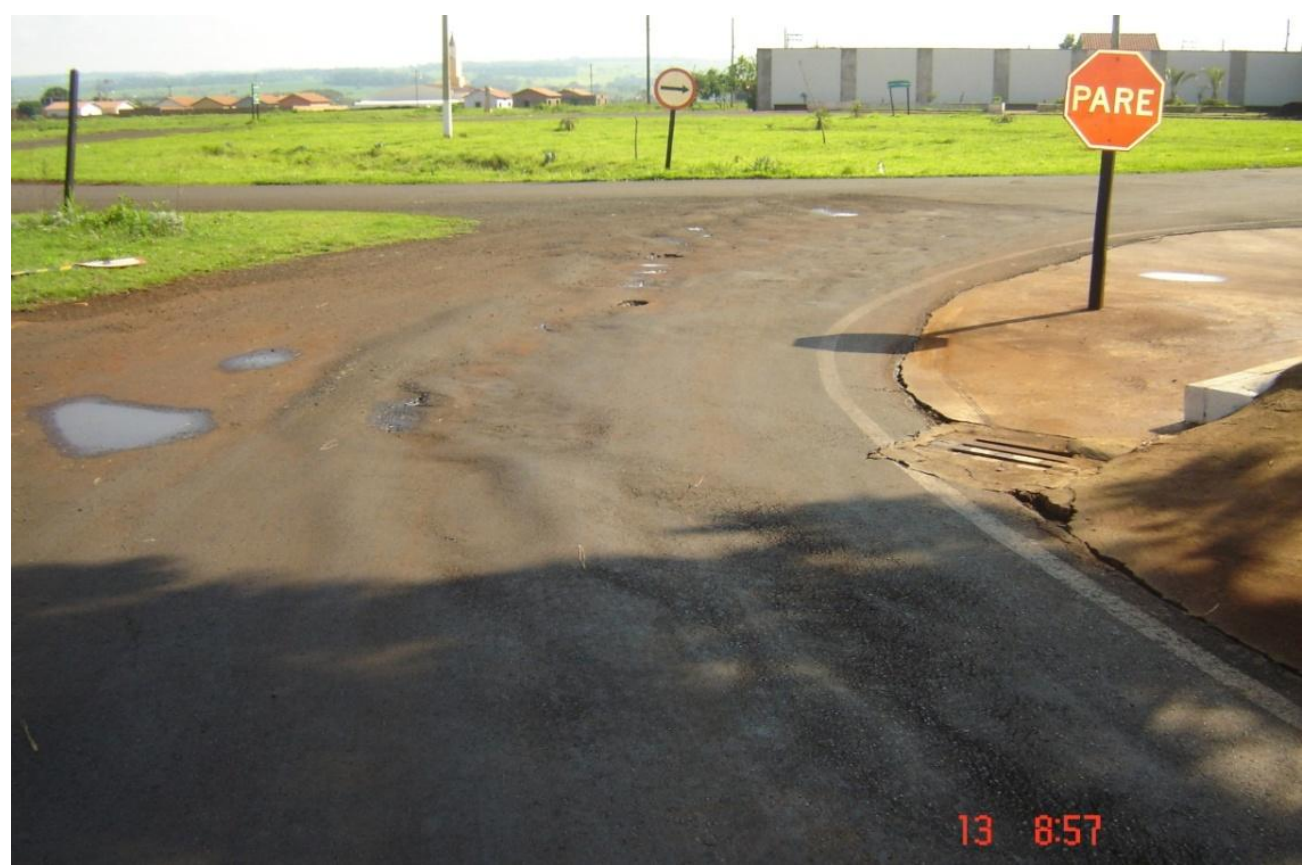

Figura 10 - Corrugação em dispositivo de acesso à rodovia Fonte: Arquivo do DER/SP

A medição desse defeito é efetuada através do registro do número de ocorrências e da área afetada (em metros quadrados). Nos trechos afetados, devem ser efetuados: remendos, reciclagem, recapeamento ou reconstrução total do pavimento.

Observa-se, nas agências dos EUA, uma classificação que se assemelha à corrugação. É o "slippage cracking" ou "trinca parabólica", que ocorre em áreas de aceleração dos veículos: o veículo vai para frente e a força de atrito 'empurra' o pavimento para trás (ele escorrega).

\subsection{5 - Defeitos superficiais: Exsudação, Agregados Polidos, Desgaste}

Novamente, o Manual de Defeitos dos EUA (FHWA, 1993) faz um agrupamento de defeitos semelhantes. Os Defeitos Superficiais apresentam: exposição de ligante em excesso, exposição de agregados ou desprendimento dos mesmos (BERNUCCI et al., 2007). A seguir estão detalhados esses três tipos de defeitos, de acordo com FHWA (1993) e Fernandes Jr. et al. (2003). 
a) A Exsudação ocorre quando existe excesso de material betuminoso na superfície do pavimento, usualmente na trilha de roda. Pode-se apresentar como um asfalto com alteração de sua coloração normal ou perda de sua textura comum. Muitas vezes o agregado mostra esse excesso de material betuminoso na sua coloração mais escura. A superfície do pavimento é mais brilhante e, às vezes, pegajosa. Podem aparecer marcas de pneus com temperaturas mais altas e pode propiciar a redução do atrito pneupavimento. Esse defeito normalmente resulta de mistura asfáltica inadequada (baixo índice de vazios).

Os níveis de severidade podem ser classificados de acordo com a situação local ou com a evolução do problema, assim sendo: 'nível baixo' é quando há alteração na coloração de certos trechos do pavimento em relação ao geral, 'nível moderado' é quando ocorre alteração da textura do pavimento, 'nível alto' é quando o pavimento apresenta aspecto brilhante e aparecem marcas de pneu no mesmo (especialmente em dias com temperatura elevada). A Figura 11 mostra três situações com ocorrência de exsudação, extraídas de DNIT 005/2003-TER (2003) e Bernucci et al. (2007).
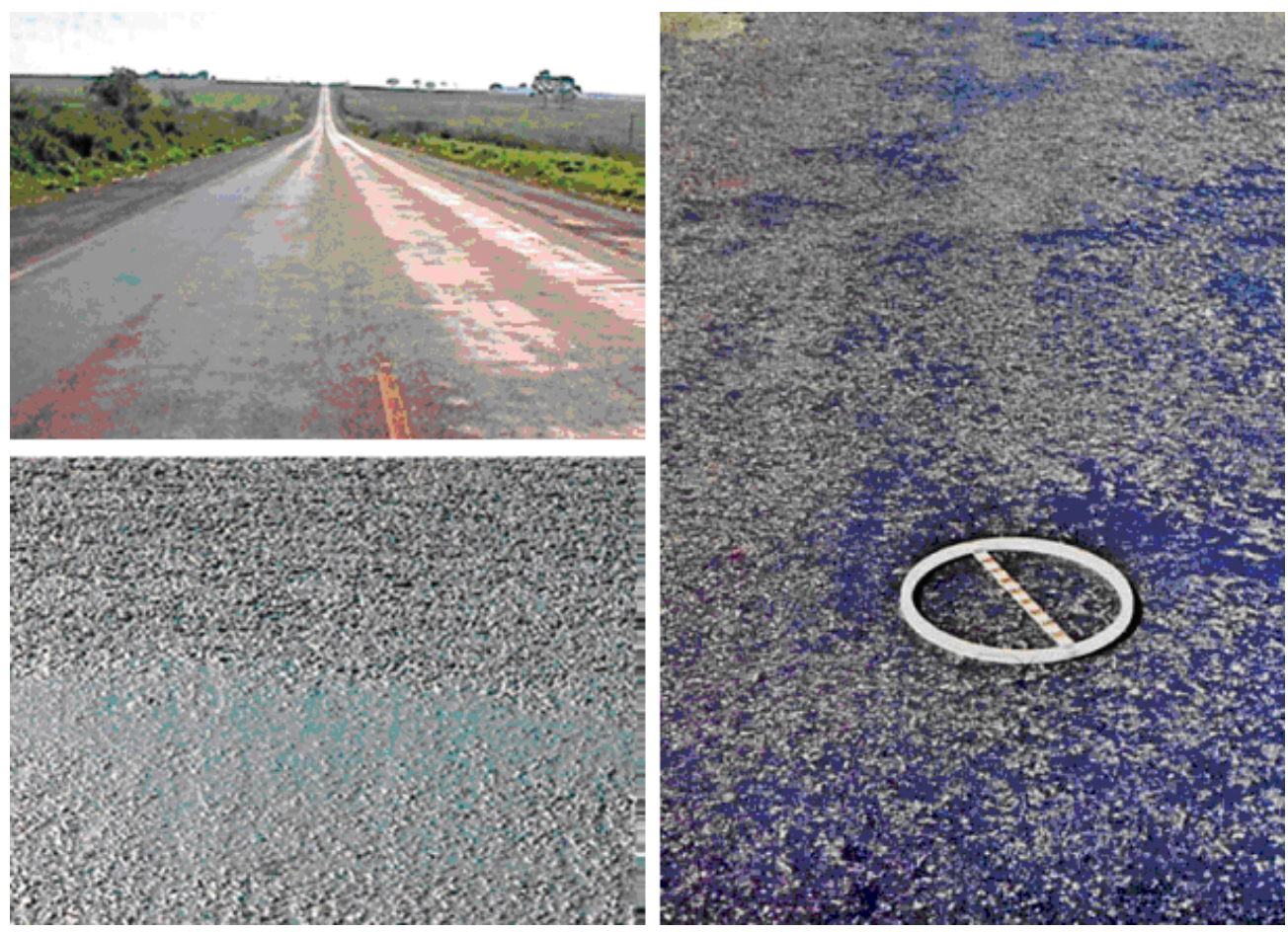

Figura 11 - Ocorrências de Exsudação

Fontes: Norma DNIT 005/2003 - TER (2003) e Bernucci et al. (2007) 
Para quantificar esse tipo de defeito é verificada a área de ocorrência, classificada por nível de severidade. A Exsudação deve ser reparada com tratamento superficial ou areia quente, ou mesmo reciclagem.

b) O Polimento ou Desgaste do Agregado e do Ligante Betuminoso podem expor o agregado graúdo, muitas vezes ocorrendo perda de material. Esse defeito pode ser resultado da ação abrasiva do tráfego, que elimina as asperezas e as angularidades das partículas. A Figura 12 ilustra ocorrência desse tipo de defeito e foi extraída do FHWA (1993).

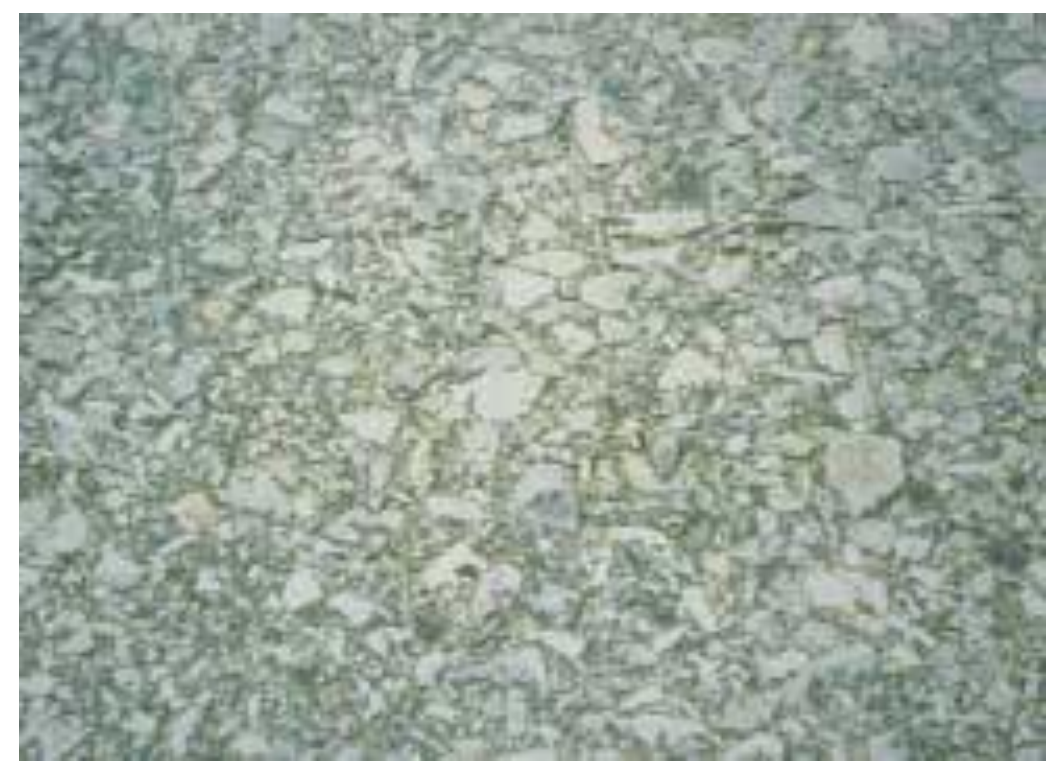

Figura 12 - Agregados Polidos

Fonte: FHWA (1993)

Não há como definir níveis de severidade. O grau de polimento pode refletir em uma redução do atrito pneu-pavimento, ocasionando um comprometimento da segurança viária. São avaliadas as áreas atingidas, em metros quadrados.

Para reparar esse defeito deve ser executado tratamento superficial ou lama asfáltica. Em alguns casos é aconselhável a execução de reciclagem, recapeamento ou reconstrução do pavimento. 
c) O Desgaste é causado pelo deslocamento de partículas de agregados e perda de adesividade do ligante asfáltico. $\mathrm{O}$ desgaste pode evoluir de perda de finos para perda de algum agregado graúdo, e, enfim, para perdas mais significativas de agregado. Essa situação ocorre devido a envelhecimento, endurecimento, oxidação, volatilização, intemperização. Quanto mais adequada é feita a mistura asfáltica (dosagem ou temperatura de execução) e, posteriormente, a aplicação da mesma (boas condições meteorológicas no momento da aplicação, correta compactação, tempo adequado para liberação ao tráfego), melhor a adesividade entre agregados e ligante asfáltico, o que diminui a probabilidade da ocorrência do desgaste precoce. A Figura 13, extraída da Norma DNIT 005/2003-TER, ilustra o aparecimento do Desgaste.

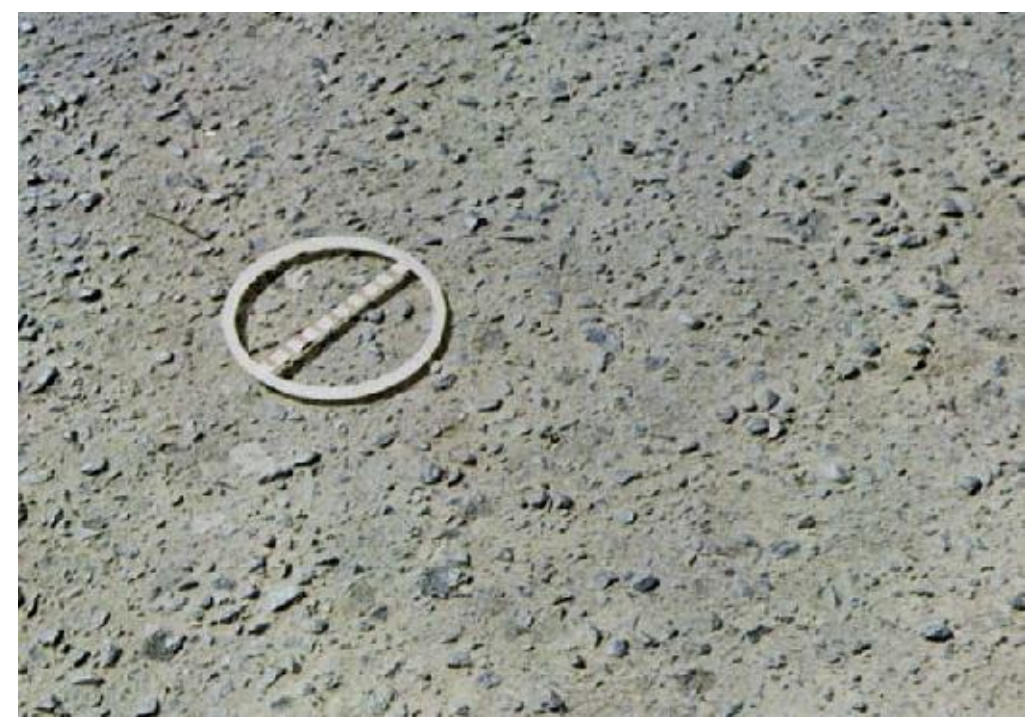

Figura 13 - Desgaste

Fonte: Norma DNIT 005/2003 - TER (2003)

Os níveis de severidade podem ser classificados de acordo com a situação local ou com a evolução do problema, assim sendo: 'nível baixo' é quando há perda de agregados miúdos, 'nível moderado' é quando a textura superficial torna-se mais áspera e ocorre perda de alguns agregados graúdos, 'nível alto' é quando a textura superficial torna-se muito áspera e ocorre perda mais intensa de agregados graúdos. A medição é feita com a quantificação da área de ocorrência, classificada em cada nível de severidade. Os reparos podem compreender a execução de: capa selante, tratamento superficial ou lama asfáltica, reciclagem ou recapeamento. 
Dentro do conceito de 'desgaste', existe uma subdivisão em algumas agências norteamericanas que classificam dois tipos desse defeito. Um deles é o "stripping", que é um tipo de desgaste que ocorre quando existe incompatibilidade de materiais e, sob ação da água, o desgaste se inicia (ocorre precocemente). E o outro é o "wear loss", que é o desalojamento de agregados em função do envelhecimento e perda de adesividade (esse desgaste ocorre com a idade do pavimento).

\subsection{6 - Outros defeitos: Desnível entre Pista e Acostamento, Bombeamento}

Em um último segmento, o Manual de Defeitos dos EUA (FHWA, 1993) faz um agrupamento de outros dois defeitos não enquadrados nas situações anteriores. As descrições dos mesmos, novamente, são as das bibliografias de FHWA (1993) e Fernandes Jr. et al. (2003).

a) O Desnível (ou degrau) entre pista e acostamento é a diferença de elevação entre a pista de rolamento e o acostamento. Normalmente, esse desnível resulta da aplicação de diferentes camadas de material, sendo que em algumas ocasiões é aplicada uma espessura maior na camada de rolamento do que no acostamento. Nos casos de acostamento não pavimentado, pode haver erosão no mesmo, ocasionando o desnível entre o acostamento e a pista de rolamento. Também pode haver consolidação diferencial entre pista e acostamento. A Figura 14, extraída de Arquivo do DER/SP, ilustra esse tipo de defeito. 


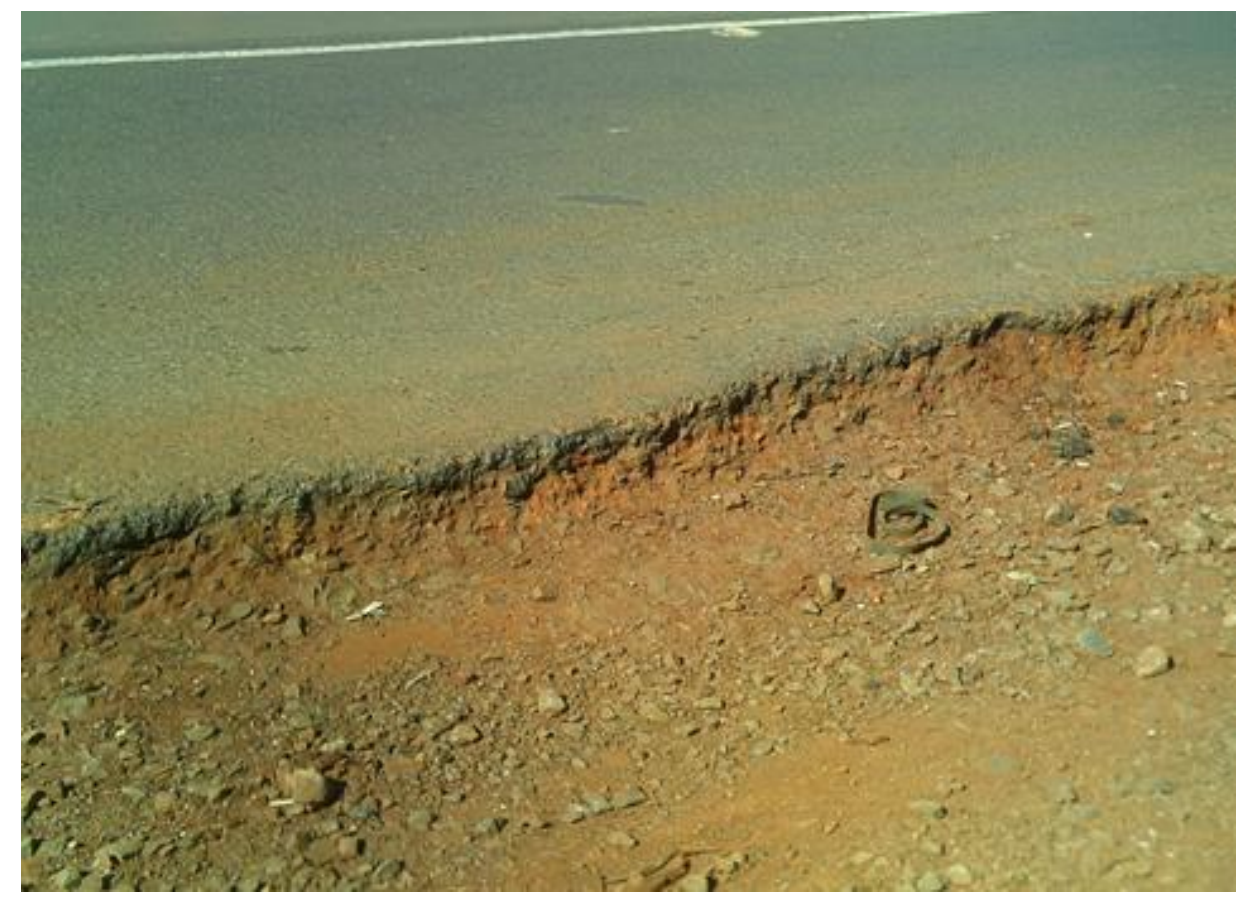

Figura 14 - Desnível entre pista de rolamento e acostamento não pavimentado Fonte: Arquivo do DER/SP

Os níveis de severidade não são aplicados neste caso. São substituídos por medições das alturas dos desníveis a cada 20m (metros) de intervalo. O reparo deste defeito consiste na recomposição do acostamento.

b) O Bombeamento é relacionado à ocorrência de ejeção de água da parte inferior do pavimento através das trincas quando sob ação das cargas do tráfego. Em alguns casos pode-se detectar esse problema através da presença de material fino na superfície do pavimento que foi erodido das camadas de apoio, ou base. Esse defeito ocorre quando existe água nos vazios sob o revestimento, ou seja, há deficiência no sistema de drenagem.

É difícil definir níveis de severidade, porque a quantidade de água bombeada pode variar de acordo com as condições de umidade. O FHWA (1993) apresenta uma ilustração desse defeito através da Figura 15. 


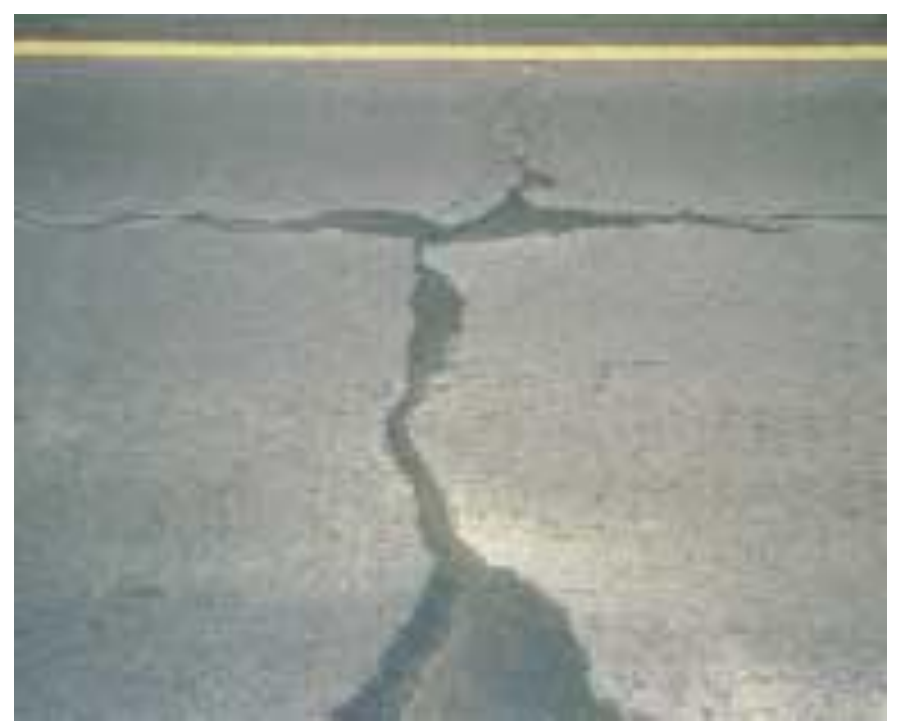

Figura 15 - Bombeamento

Fonte: FHWA (1993)

Para quantificar esse defeito, registram-se o número de ocorrências e a área atingida. Deve ser recuperado o pavimento de acordo com a necessidade e, para se evitar nova ocorrência do bombeamento, deve ser corrigido o sistema de drenagem no local.

\subsection{Defeitos em Pavimentos de Concreto Asfáltico - Normas Francesas}

O LCPC (Laboratoire Central des Ponts et Chaussées) publicou, em 1972, um 'catálogo das degradações dos pavimentos', estabelecido pelo CCT (Centre Coordonnateur des Trappes), com o auxílio de engenheiros dos 'Pontos de Apoio ao Reforço’ (PAR) dos Laboratórios Regionais. Esse catálogo foi seguido em 1977 pelo 'guia de auscultação dos Pavimentos Flexíveis', no qual um capítulo foi dedicado à classificação, ao levantamento e à quantificação dos defeitos de superfície dos pavimentos. Depois da época dos reforços, veio a da conservação preventiva das rodovias nacionais e, em 1979, a Direção das Estradas e da Circulação Rodoviária publicou uma coleção das degradações, elaborada e difundida pelo LCPC e pelo SETRA (Service D'Estudes Techniques des Routes et Autoroutes), este último, órgão que trata da Direção das Estradas. Foi utilizada a versão de 1998 dessa coleção (ou catálogo) de degradações. Em seguida, surgiu o VIZIR, um método de 'avaliação da qualidade da rede' para as sequentes tomadas de decisões. 


\subsection{1 - Introdução}

As normas francesas dão um tratamento diferenciado aos defeitos encontrados no pavimento rodoviário. Esses defeitos são separados em: degradações estruturais e degradações não ligadas a problemas estruturais. Nas especificações descritas em sequência, alguns tipos de defeitos não têm suas causas detalhadas.

\subsection{2 - Degradações estruturais}

De acordo com LCPC (1998) e Autret \& Brousse (2001), as degradações estruturais podem estar localizadas somente na superfície (revestimento) ou atingir as camadas mais profundas (base, sub-base, subleito, reforço do subleito). Elas ocorrem quando a capacidade estrutural do pavimento é insuficiente. Esses tipos de defeitos estão subdivididos em: trincas por fadiga, deformação permanente e remendos. Normalmente ocorrem nas trilhas de roda, principalmente na circulação de veículos pesados. Esses defeitos são ilustrados nas Figuras 16, 17 e 18. As ilustrações foram extraídas de Bernucci et al. (2007).

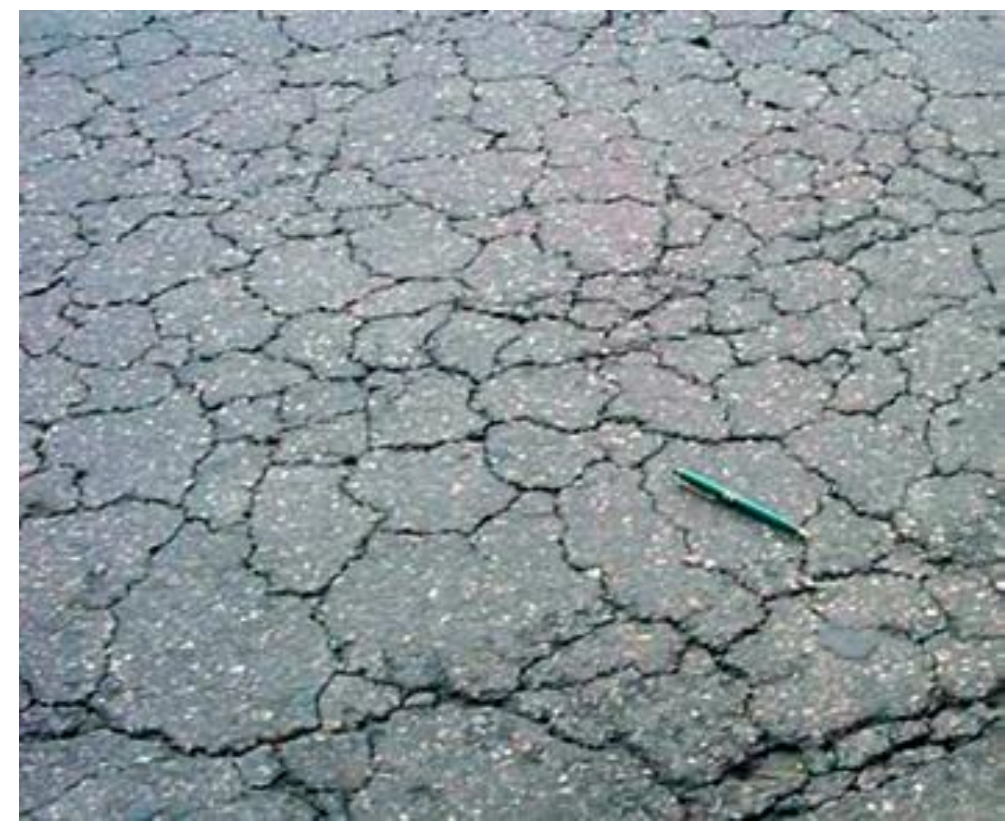

Figura 16 - Trincas por fadiga - segunda ilustração

Fonte: Bernucci et al. (2007) 


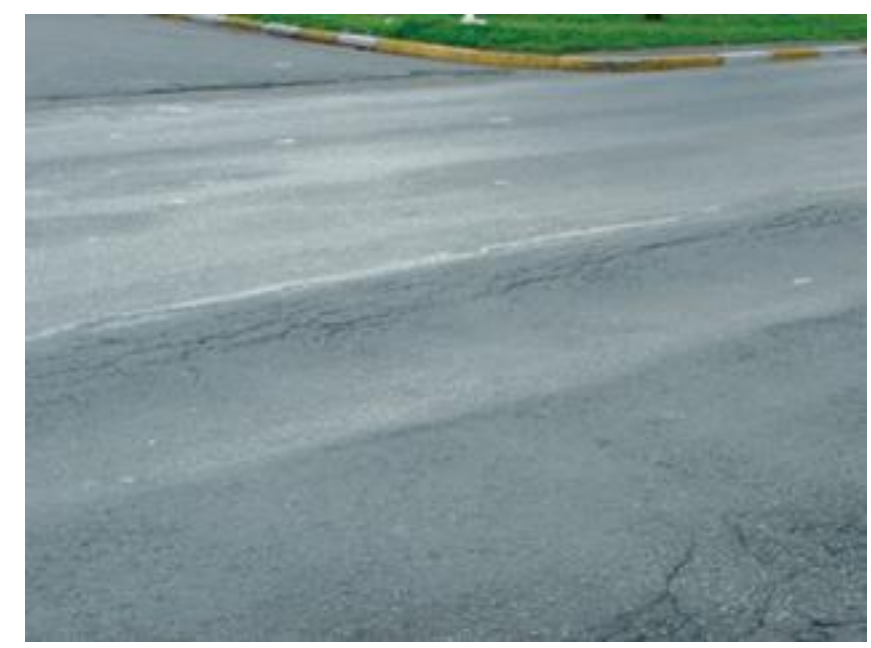

Figura 17 - Deformação permanente - segunda ilustração

Fonte: Bernucci et al. (2007)

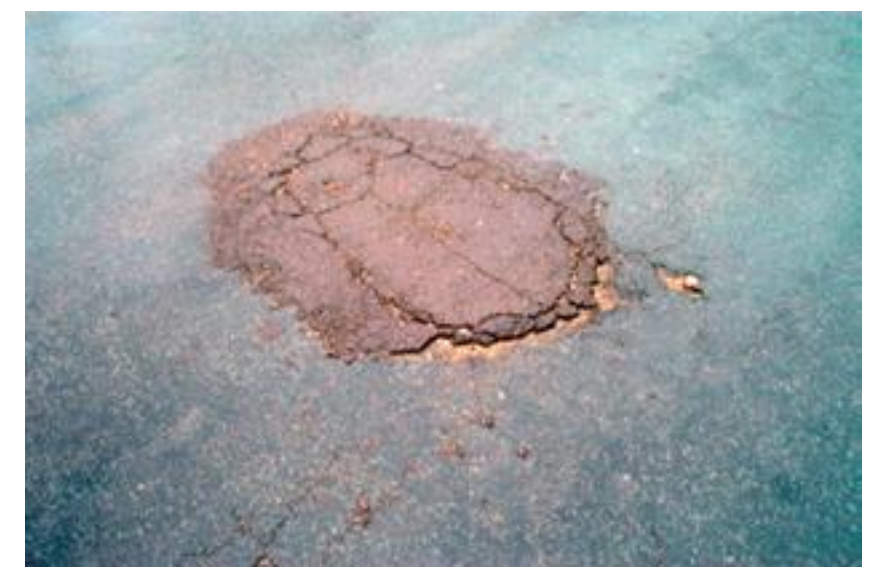

Figura 18 - Remendo 'mal' executado

Fonte: Bernucci et al. (2007)

Os três tipos de defeitos são descritos, na sequência, conforme LCPC (1998) e Autret \& Brousse (2001).

a) A Deformação permanente aparece como consequência de suporte insuficiente das camadas inferiores ao revestimento, má qualidade das camadas de suporte e diminuição da capacidade de suporte devido à deficiência de drenagem. As causas podem variar em virtude do tipo de base. Essa deformação aparece na trilha de roda, a uma distância de 50 a $80 \mathrm{~cm}$ do bordo. Surge devido ao recalque dos materiais sob um tráfego pesado e canalizado, associado ou não a uma queda de resistência das camadas inferiores. 
A gravidade varia entre fraca (até $2 \mathrm{~cm}$ de altura), média ( 2 a $4 \mathrm{~cm}$ de altura) e elevada (acima de $4 \mathrm{~cm}$ ). Neste ponto vale comparar que, para o SHRP, os níveis de severidade podem ser: baixo (até 2,5 cm), moderado (entre 2,5 e 5,0 cm), alto (acima de 5,0 cm), ou seja, bastante semelhantes.

Dentro dessa classificação, pode-se enquadrar o 'afundamento localizado ou pontual' ("affaissement hors rive" ou "flache"), que também pode ser originado pelas mesmas causas acima com a diferença de ficar restrito a uma pequena área (quase um ponto). Pode ser localizado, ou não, na trilha de roda.

b) As Trincas por fadiga ocorrem pela ação constante do tráfego rodoviário que submete o pavimento a cargas repetidas (continuadas), com o tempo podem ocorrer fissuras na superfície do pavimento originando as 'trincas por fadiga'. Podem evoluir até apresentar um aspecto de 'couro de jacaré ou crocodilo'. Surge, preferencialmente, nas trilhas de roda.

Dentro dessa classificação, enquadra-se um tipo de trinca circular ("faiençage circulaire") que acaba levando à ocorrência da trinca por fadiga de maneira mais abrangente, normalmente também na trilha de roda. A Figura 19, extraída do LCPC (1998), esquematiza esse tipo de trinca circular.

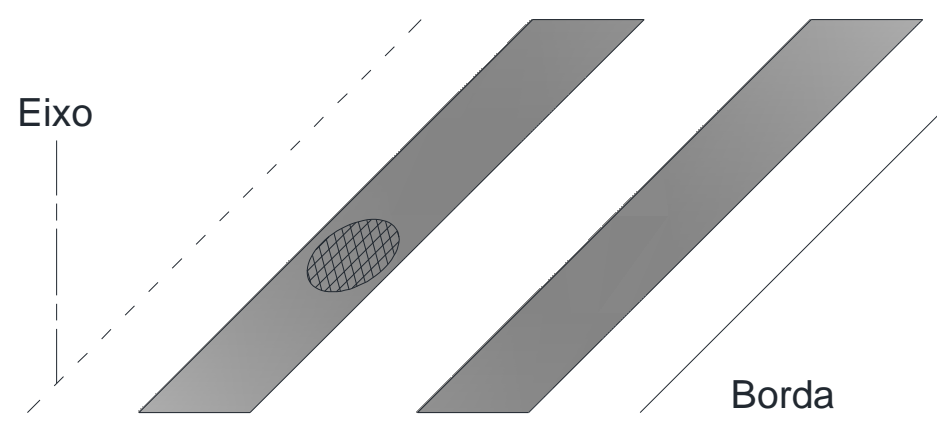

Figura 19 - Trinca circular

Fonte: LCPC (1998) 
c) Os Remendos são efetuados para regularizar o pavimento, quando ocorrem defeitos superficiais ou profundos no mesmo. Um remendo pode 'mascarar' um problema. Caso os remendos sejam frequentes num mesmo local, pode significar que o problema não foi solucionado. A ocorrência constante de remendos pode indicar necessidade de reparos na estrutura no pavimento.

\subsection{3 - Degradações não ligadas a problemas estruturais}

De acordo com LCPC (1998) e Autret \& Brousse (2001), as degradações não ligadas a problemas estruturais são defeitos não associados a problemas com a capacidade estrutural do pavimento. São causadas por problemas no momento da construção, seja: na qualidade de um determinado material utilizado, na maneira como a mistura asfáltica foi elaborada, na maneira como a base e o revestimento foram executados. Também podem surgir em virtude de uma condição local específica aliada ao tráfego. Podem abranger outras trincas que não a 'trinca por fadiga' (longitudinais, em bloco, transversais, nos bordos), desgaste, exsudação, corrugação, descascamento, penteadura, panelas (ou buracos), desnível entre pista e acostamento.

Os vários defeitos classificados como não originados por problemas estruturais são explanados na sequência, sob a visão do LCPC (1998) e Autret \& Brousse (2001).

a) As Trincas longitudinais são descritas como um tipo de defeito resultante de uma imperfeição na colagem de duas faixas de pré-misturados contíguas. Nesse caso a trinca longitudinal não aparece, obrigatoriamente, na trilha de roda. Nos casos onde a trinca longitudinal aparece na trilha de roda, é provável que haja um defeito do tipo 'degradação estrutural'.

b) As Trincas nos bordos surgem nas proximidades do acostamento, quando o mesmo não é pavimentado. Podem ser causadas por dimensionamento inadequado das camadas do pavimento, má compactação, problemas de drenagem, situações específicas do clima ou excesso de vegetação nos bordos dificultando a saída d'água. 
c) As Panelas ou buracos aparecem em decorrência do desgaste ou da destruição da camada de rolamento. No início, suas dimensões são reduzidas. Caso não seja corrigido, suas dimensões podem aumentar consideravelmente, conduzindo até mesmo à remoção do pavimento. Inicia-se no revestimento, mas pode atingir a base se não for reparado.

É importante ressaltar que, embora na maior parte dos casos o defeito Panela ou Buraco tenha sua origem em problemas diversos, em alguns casos pode ter origem estrutural.

d) As Trincas transversais podem ocorrer pela variação de temperatura muito grande, principalmente em países de climas frios.

e) As Trincas em blocos compreendem um conjunto de fissuras longitudinais e transversais que se unem e formam uma rede de malha. Surgem devido a contrações após a aplicação da mistura asfáltica.

f) O Desgaste aparece, inicialmente, como uma perda de material reduzida. Com o passar do tempo essa perda vai se acelerando e comprometendo a qualidade do pavimento.

g) A Exsudação ocorre quando o excesso de ligante surge na superfície.

h) A Corrugação pode aparecer em consequência de má compactação, quando existe uma forte solicitação do pavimento, principalmente em curvas ou rampas acentuadas, ou locais sujeitos a frenagem e acelerações constantes.

Dentro dessa classificação podem-se enquadrar alguns defeitos pontuais ("gonfle"), nem sempre localizados em locais sujeitos a frenagem e acelerações constantes, mas com características semelhantes (aparenta um 'estufamento' no pavimento). Surgem em virtude de incompatibilidades químicas ou mesmo má compactação. 
i) O Descascamento surge quando partes da camada de rolamento soltam-se (descolam) da base ou do revestimento anterior, no caso de manutenção preventiva ou de recapeamento delgado (microrrevestimentos asfálticos e tratamentos superficiais, por exemplo). Esse defeito é considerado, nas normas norte-americanas, como buraco ou panela, ainda que, em virtude da pequena espessura, tenha severidade baixa. Pode ocorrer, também, quando algumas 'panelas' de severidade baixa são reparadas e o material aplicado não adere de maneira adequada às camadas inferiores. Sugere-se, portanto, que, nas normas brasileiras, esse defeito seja enquadrado junto com o defeito Buraco ou Panela.

j) A Penteadura surge em razão de má execução da camada asfáltica em tratamento superficial, geralmente provocada por uma distribuição irregular do ligante pela espargidora (falha do bico espargidor), ou, ainda, em virtude de distribuição inadequada de agregados no pavimento. Esse defeito não é considerado nas normas dos Estados Unidos, que consideram apenas os concretos asfálticos usinados a quente e não incluem tratamentos superficiais. A Figura 20, extraída de Loiola (2009), ilustra esse defeito.

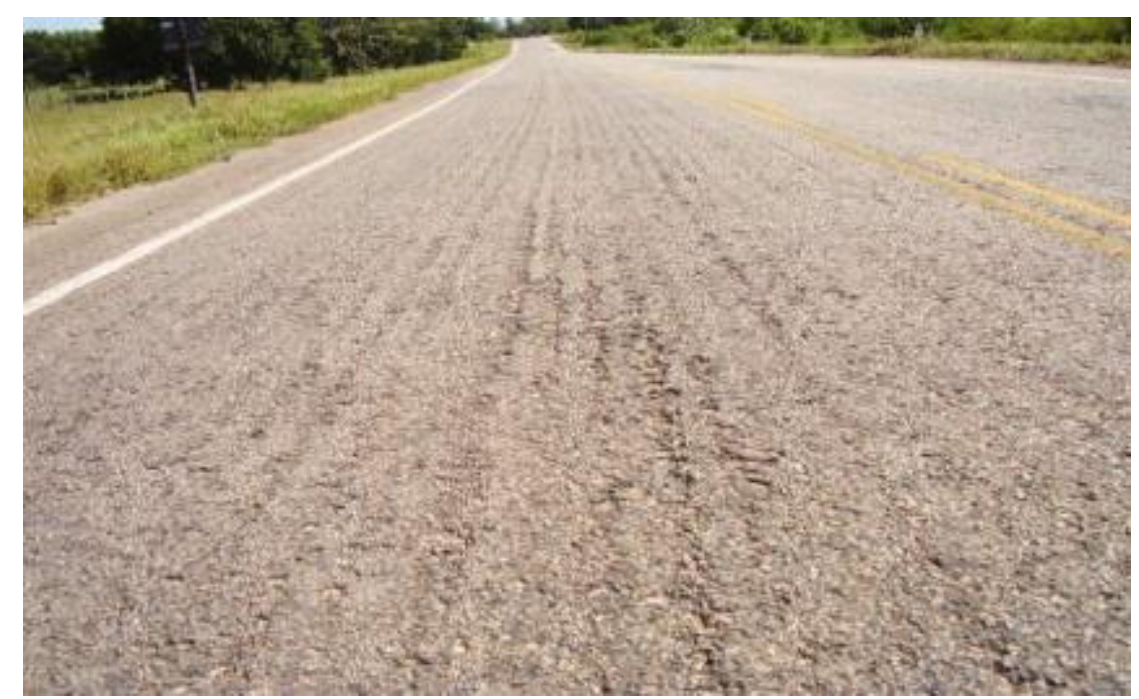

Figura 20 - Penteadura

Fonte: Loiola (2009) 
k) O Desnível entre pista e acostamento (mais comum no caso de acostamento pavimentado) e a erosão no acostamento (no caso de acostamento sem pavimento) surgem, normalmente, devido a falhas construtivas ou deficiência na conservação rotineira. Podem ocorrer os dois defeitos no limite entre pista de rolamento e acostamento. No caso de acostamento pavimentado, pode haver desnível acentuado entre ambos, o que provoca um degrau perigoso a ser transposto pelo usuário da rodovia. No caso de acostamento não pavimentado, pode haver erosão no mesmo, que também irá comprometer a segurança do tráfego, essa erosão poderá chegar até a rodovia, agravando ainda mais a situação da mesma. Também pode haver consolidação diferencial entre pista e acostamento, de acordo com FHWA (1993) e Fernandes Jr. et al. (2003).

A gravidade deste defeito deve ser citada, tendo em vista sua inexistência em outras normas. As graduações são: gravidade 1 ou baixa severidade com desnível de 1 a 5 $\mathrm{cm}$, gravidade 2 ou média severidade com desnível entre 5 e $10 \mathrm{~cm}$, gravidade 3 ou alta severidade com desnível acima de $10 \mathrm{~cm}$.

\subsection{4 - Comparação entre os níveis de severidade segundo a França e os outros países}

Dentro das especificações dos órgãos técnicos franceses, existem algumas orientações sobre como medir os diversos tipos de defeitos (gravidade, extensão, outras). Essas orientações não se encontram detalhadas nesta dissertação, pelo fato das orientações dos EUA serem mais simples e precisas. No caso das trincas por fadiga (degradação estrutural) ou demais trincas (de bordo, em blocos, transversais, longitudinais, por reflexão) as normas francesas não apresentam indicações de valores (espessuras ou larguras) a serem considerados para classificação de severidade. Essas normas utilizam as expressões 'claramente abertas' ou 'muito abertas', para mensurar as trincas por fadiga, que podem deixar margem a interpretações variadas entre os avaliadores. Já nas normas dos Estados Unidos existem parâmetros para se classificar esses níveis de severidade, deixando um menor número de detalhes a serem avaliados pelo 'bom senso' dos técnicos responsáveis. 
Os buracos tem suas dimensões para classificação em níveis de severidade bem definidas apenas nos manuais dos EUA. No caso da corrugação, as normas francesas não indicam nenhum valor, assim como as norte-americanas, mas estas vinculam a gravidade ao 'quanto a segurança é afetada'. Já no caso dos defeitos exsudação e desgaste, apesar de não serem apresentados valores em nenhuma das normas analisadas até esse ponto, no caso das norte-americanas esses defeitos tem sua evolução constantemente monitorada. Os níveis de severidade desses defeitos são indicados em Fernandes Jr. et al. (2003). Agregados polidos e bombeamento são mencionados somente nas normas norte-americanas, entretanto é importante a avaliação desses defeitos tendo em vista sua ocorrência constante nos pavimentos brasileiros. No caso dos agregados polidos é avaliada a variação do atrito pneupavimento, no caso do bombeamento não há como se avaliar a severidade. $O$ descascamento, somente citado aqui, é enquadrado como buraco ou panela para comparação com outras normas. A penteadura também é citada somente na norma francesa e não são quantificados valores para classificação de seus níveis de gravidade.

Foi citada a classificação da gravidade da deformação permanente, entre 2 e $4 \mathrm{~cm}$, bastante semelhante à adotada pelos Estados Unidos, entre 2,5 e 5 cm (HAAS, 1994), para fins de comparação. O defeito Desnível entre Pavimento e Acostamento cita valores para classificação por nível de severidade apenas nas normas francesas. Neste caso específico deve ser utilizada a orientação francesa que é bastante simples.

Uma última consideração a ser feita é sobre a análise dos Remendos. A Norma Francesa cita que os remendos podem ser classificados em dois tipos: um que suprime completamente o defeito, provavelmente, é um remendo referente a degradações do tipo 'de origens outras que não estruturais', e outro que suprime parcialmente o defeito, provavelmente, é um remendo referente a degradações do tipo 'de origem estrutural'. Essa diferenciação pode ser importante para a tomada de decisões com relação à recuperação do pavimento e deve ser levada em conta para se classificar por níveis de severidade. Valores numéricos são indicados apenas nas normas dos EUA. 


\subsection{Defeitos em Pavimentos de Concreto Asfáltico - Normas do DNIT / Brasil (DNIT, 2006; NORMA DNIT-005, 2003)}

Um dos objetivos do Manual de Restauração de Pavimentos Rodoviários do DNIT, utilizado como fonte para esse tópico, é apresentar e discutir os elementos técnicos necessários à identificação, quantificação e análise das deteriorações existentes nos pavimentos asfálticos. São discutidas técnicas para avaliação da capacidade estrutural dos pavimentos, métodos de determinação de sua habilidade de proporcionar conforto ao rolamento e segurança, métodos para dimensionamento de reforço de pavimentos e medidas de controle da qualidade dos serviços de restauração. Outro objetivo é apresentar um processo para a seleção da melhor estratégia de restauração dos pavimentos flexíveis. Dentro do desenvolvimento do Manual, o principal ponto observado neste trabalho é a apresentação dos principais defeitos que podem ocorrer nos pavimentos asfálticos durante sua vida útil, suas causas, processos de avaliação estrutural e funcional dos pavimentos.

\subsection{1 - Introdução}

Para que seja possível executar uma boa recuperação do pavimento, é necessário identificar qual foi a causa da deterioração específica ocorrida no local. Também é necessário se determinar qual o momento exato para intervir e qual a intervenção que será efetuada. Cabe aqui ressaltar o conceito de Gerência de Pavimentos, que trabalha a otimização de utilização de recursos e o momento exato de se efetuar as intervenções para obter o melhor retorno econômico. Uma inter-relação entre desempenho dos pavimentos, estratégia de manutenção e reabilitação, data da intervenção e custos pode ser observada na Figura 21, extraída de Fernandes Jr. et al. (2003). 


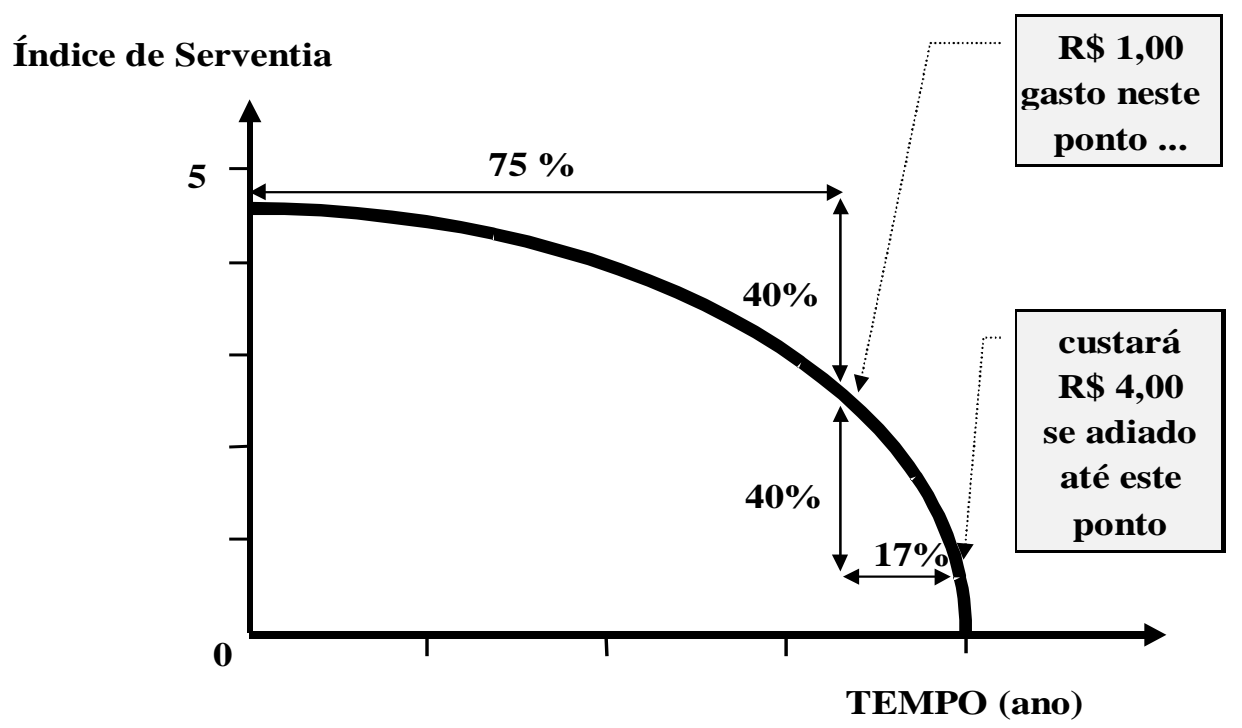

Figura 21 - Inter-relação entre desempenho dos pavimentos, estratégia de manutenção e reabilitação, data da intervenção e custos

Fonte: Fernandes Jr. et al. (2003)

\subsection{2 - Classificação}

Visando à deflagração de intervenções de restauração, o DNIT (2006) leva em consideração os seguintes defeitos:

$\checkmark$ Trincamento (principalmente por fadiga)

$\checkmark$ Desgaste

$\checkmark$ Buraco (Panela)

$\checkmark$ Remendos

$\checkmark$ Deformação permanente (afundamento nas trilhas de roda)

$\checkmark$ Irregularidade funcional ('associa-se a' ondulação ou corrugação e escorregamento)

$\checkmark$ Resistência à derrapagem ('associa-se a' exsudação)

Os quatro primeiros são denominados defeitos de superfície (embora possam abranger as camadas inferiores também). A deformação permanente e a irregularidade funcional envolvem deformações nas camadas inferiores. A resistência à derrapagem aparece no comprometimento no curso normal do tráfego e é função de problemas na textura do pavimento. 
É importante ressaltar que essa classificação apresenta incoerências em relação aos 'defeitos' realmente assim entendidos. A Irregularidade Funcional pode ser causada por Ondulação ou Corrugação e Escorregamento, estes sim 'defeitos' e não a irregularidade propriamente dita. $\mathrm{O}$ mesmo pode ser comentado em relação ao item Resistência à Derrapagem que se entende estar associado ao 'defeito' Exsudação (que irá diminuir essa resistência e tornar a via insegura). Vale acrescentar, ainda, que a Resistência à Derrapagem, em muitos casos, é um defeito superficial sem atingir as camadas inferiores. Tendo em vista esses comentários, foram detalhados os defeitos realmente ocorrentes, e não os acima citados.

Outra classificação também é citada pelo DNIT, tentando obter uma padronização com as normas estrangeiras, assumindo uma subdivisão em dois grandes blocos:

$\checkmark$ Fendas, que se subdivide em: Trincas isoladas (transversais ou longitudinais) e Trincas interligadas (por fadiga ou tipo 'couro de jacaré', ou em bloco);

$\checkmark$ Outros defeitos, que se subdivide em: Afundamentos (plástico ou de consolidação), Ondulação ou corrugação, Escorregamento, Exsudação, Desgaste, Panelas ou buracos, Remendos.

Nos comentários, a seguir, houve uma tentativa de conciliação entre as duas classificações apresentadas pelo DNIT, procurando a melhor coerência entre ambas e as outras normas internacionais tratadas neste trabalho.

\subsection{3 - Trincamento (DNIT, 2006; NORMA DNIT-005, 2003)}

O trincamento pode se apresentar em forma de fendas, fissuras, trincas isoladas longitudinais ou transversais, trincas interligadas (aparentando couro de jacaré) ou ainda trincas em bloco (DNIT, 2006). 
A fissura é uma fenda capilar existente no pavimento perceptível a uma distância inferior a $1,50 \mathrm{~m}$. Como não causa problemas funcionais ao revestimento não é considerada quanto à gravidade nos métodos de avaliação das condições do pavimento. (NORMA DNIT-005, 2003). A trinca é uma fenda perceptível a uma distância superior a 1,50m, podendo apresentar-se sob a forma de trinca isolada ou trinca interligada. (NORMA DNIT-005, 2003)

Podem ser classificados como FC-1, FC-2, FC-3, dependendo das dimensões das mesmas (o número 1 - 2 - 3 considera o aumento de gravidade do defeito).

Esse tipo de defeito pode ser causado pelas seguintes ocorrências:

$\checkmark$ tráfego atuante que, pelo ciclo de carregamento e alívio, promove tensões de tração na fibra interior do revestimento;

$\checkmark$ alternância na mudança diária de temperatura, que acusam contrações do revestimento existente;

$\checkmark$ reflexão no revestimento de trincas existentes em bases cimentadas (base de solo cimento).

No Manual do DNIT (2006) não há detalhamento de fenda, fissura ou das variadas trincas. Existe detalhamento dos vários tipos de trinca na Norma DNIT-005/2003-TER e é citado nos itens a seguir.

O Manual do DNIT também faz uma citação à parte de três tipos de trincas: por fadiga, por envelhecimento, de reflexão. O primeiro tipo citado (por fadiga) tem relação com a situação de ciclo de carregamento e alívio. No segundo tipo de trinca (por envelhecimento) tem maior peso o endurecimento do asfalto que ocorre com a perda de flexibilidade do ligante. A 'idade' dessa ocorrência depende: da resistência à oxidação do ligante (composição química ou origem do petróleo), da temperatura ambiente e da espessura de filme do ligante. O terceiro tipo de trinca (por reflexão) ocorre quando existe trinca nas camadas inferiores e esse problema propaga-se nas camadas superiores. 
Essa classificação pode trazer dúvidas à maneira de se classificar o defeito Trinca e suas várias subdivisões, inclusive, mudando conceitos já estabelecidos sobre as causas e as apresentações desses defeitos diversos. A trinca por fadiga surge em consequência da situação de carregamento e alívio, mas não deve surgir precocemente como parece sugerir o primeiro item, normalmente isso ocorre se o pavimento foi maldimensionado ou se as cargas a que o pavimento foi submetido excederam ao que foi projetado inicialmente. Com o passar do tempo, tende a surgir a trinca por fadiga, em razão do envelhecimento natural do pavimento e do final da sua vida útil já previsto no projeto (segundo tipo de trinca citado nesta classificação do Manual). A trinca por reflexão é uma classificação a parte, não devendo ser confundida com trinca por fadiga.

É possível se constatar que os detalhamentos do defeito denominado 'trincas' e suas várias subdivisões, das normas norte-americanas e francesas, abrangem essas três subdivisões acima, sendo mais claros, coerentes e conceitualmente adequados.

\subsection{4 - Trinca Isolada Transversal (NORMA DNIT-005, 2003)}

É a trinca isolada que surge com direção predominantemente ortogonal ao eixo da via. Se sua extensão é inferior a $100 \mathrm{~cm}$ é chamada trinca transversal curta. Se sua extensão é superior a $100 \mathrm{~cm}$ é chamada trinca transversal longa.

\subsection{5 - Trinca Isolada Longitudinal (NORMA DNIT-005, 2003)}

É a trinca isolada que surge com direção predominantemente paralela ao eixo da via. Se sua extensão é inferior a $100 \mathrm{~cm}$ é chamada trinca longitudinal curta. Se sua extensão é superior a $100 \mathrm{~cm}$ é chamada trinca longitudinal longa. 
2.4.6 - Trinca Isolada de Retração (NORMA DNIT-005, 2003)

É a trinca isolada atribuída aos fenômenos de retração térmica, ou do material do revestimento ou do material de base rígida ou semirrígida, subjacentes ao revestimento trincado. Comparando as normas brasileiras com as demais, esse tipo de trinca parece estar associado à Trinca Transversal ou Longitudinal fora das trilhas de roda.

2.4.7 - Trinca Interligada tipo "Couro de Jacaré" ou por fadiga (NORMA DNIT-005, 2003)

É o conjunto de trincas, sem direções preferenciais, assemelhando-se ao aspecto de couro de jacaré. Pode apresentar, ou não, erosão acentuada nas bordas.

2.4.8 - Trinca Interligada tipo "Bloco" (NORMA DNIT-005, 2003)

É o conjunto de trincas interligadas caracterizadas pela configuração de blocos formados por lados bem definidos. Pode, ou não, apresentar erosão acentuada nas bordas.

2.4.9 - Desgaste (DNIT, 2006; NORMA DNIT-005, 2003)

O desgaste é a perda de agregados ou argamassa fina do revestimento asfáltico. Caracteriza-se pela aspereza superficial anormal, com perda do envolvimento betuminoso e arrancamento progressivo dos agregados, devido aos esforços tangenciais causados pelo tráfego. 
Esse defeito pode ser provado pelos seguintes motivos:

$\checkmark$ redução da ligação entre o agregado e o ligante devido à oxidação do ligante, e pela ação combinada do tráfego e dos agentes intempéricos;

$\checkmark$ perda de coesão entre agregado e ligante devido à presença de poeira ou sujeira no momento da construção;

$\checkmark$ execução da obra em condições meteorológicas desfavoráveis;

$\checkmark$ presença de água no interior do revestimento que originam sobrepressões hidrostáticas capazes de provocar o descolamento da película betuminosa;

$\checkmark$ deficiência localizada de ligante asfáltico nos serviços por penetração decorrente de entupimento dos bicos ou má regulagem da barra espargidora.

Como resultado das causas prováveis acima, o ligante asfáltico fica impossibilitado de promover a retenção dos agregados que se soltam progressivamente sob a ação das cargas de tráfego.

Note-se que esse defeito está descrito de forma bastante detalhada no Manual do DNIT (2006), complementando ao que já foi apresentado nas normas anteriores.

\subsubsection{0 - Buracos ou Panelas (DNIT, 2006; NORMA DNIT-005, 2003)}

Buracos ou Panelas são cavidades formadas inicialmente no revestimento do pavimento e que possuem dimensões e profundidades variadas. Esse defeito é muito grave, pois afeta estruturalmente o pavimento, permitindo o acesso das águas superficiais ao interior da estrutura. Também é grave do ponto de vista funcional, já que afeta a irregularidade longitudinal e, como consequência, a segurança do tráfego e o custo do transporte.

As principais causas deste defeito podem estar relacionadas a:

$\checkmark$ trincamento por fadiga (estágio terminal);

$\checkmark$ desintegração localizada na superfície do pavimento (desgaste de alta severidade). 
Também pode ocorrer por falta de aderência entre as camadas superpostas, causando o desplacamento das camadas. Tanto o início desta falha quanto a sua evolução são aceleradas pela ação do tráfego e de fatores climáticos.

\subsubsection{1 - Remendo (DNIT, 2006; NORMA DNIT-005, 2003)}

Esse tipo de defeito pode ser definido como uma porção do pavimento onde o material original foi removido e substituído por outro (similar ou diferente). Seu surgimento advém de problemas estruturais ou superficiais do pavimento. Ocorre por diversos motivos, em geral oriundo de ação conjunta de tráfego e condições ambientais.

Pode ser profundo, quando há substituição do revestimento e de uma ou mais camadas inferiores do pavimento, ou pode ser superficial, quando é localizado apenas na superfície do revestimento.

\subsubsection{2 - Afundamento ou Deformação Permanente (DNIT, 2006; NORMA DNIT-005,} 2003)

É caracterizado por uma depressão na superfície do pavimento, com ou sem solevamento, apresentando-se sob a forma de:

$\checkmark$ afundamento plástico, causado pela fluência plástica de uma ou mais camadas do pavimento ou do subleito, acompanhado de solevamento; se sua extensão é de até 6 m é chamado de afundamento plástico local, se sua extensão é superior a 6 m é chamado de afundamento plástico de trilha de roda;

$\checkmark$ afundamento de consolidação causado por consolidação diferencial de uma ou mais camadas de pavimento ou do subleito, sem estar acompanhado de solevamento; se sua extensão é de até $6 \mathrm{~m}$ é chamado de afundamento de consolidação local, se sua extensão é superior a 6 m é chamado de afundamento de consolidação de trilha de roda. 
É uma falha caracterizada pelo aparecimento de ondulações ou corrugações transversais, de caráter plástico e permanente, no revestimento asfáltico.

Pode ser causada por:

$\checkmark$ instabilidade na mistura betuminosa do revestimento ou da base;

$\checkmark$ excesso de umidade das camadas subjacentes;

$\checkmark$ contaminação da mistura por materiais estranhos;

$\checkmark$ retenção de água na mistura asfáltica.

É mais comum esse defeito surgir em regiões de aceleração e frenagem de veículos.

2.4.14 - Escorregamento (DNIT, 2006; NORMA DNIT-005, 2003)

É um movimento horizontal do revestimento, causado por esforços tangenciais transmitidos pelos eixos dos veículos (frenagem e aceleração), que produzem uma ondulação curta e abrupta no pavimento em forma de meia lua. Ocorre um deslocamento do revestimento em relação à camada subjacente do pavimento

Pode ser causado por:

$\checkmark$ ligação inadequada entre revestimento e camada subjacente;

$\checkmark$ inércia limitada do revestimento em virtude de espessura reduzida;

$\checkmark$ compactação deficiente;

$\checkmark$ fluência plástica em decorrência de temperaturas elevadas.

Esse defeito aparece em regiões de aceleração e desaceleração, tais como: aclives e declives, curvas de raio pequeno, interseções e paradas de ônibus ou obstáculos. 
Nas normas norte-americanas, é citado o defeito 'escorregamento' e o defeito 'corrugação' como sendo um único defeito a ser considerado. Nas normas francesas só é citado o defeito 'corrugação'. É possível se constatar que fica mais clara e coerente a classificação desses manuais ao invés da classificação do DNIT. Segundo a descrição desses defeitos pelo Manual do DNIT (2006), a forma desses defeitos é ligeiramente diferenciada, mas na prática essa diferenciação é pouco visível. As causas desses dois defeitos também são detalhadas de maneira mais simples nos outros manuais (norteamericano e francês), sendo as mesmas, no entender daqueles órgãos técnicos.

\subsubsection{5 - Exsudação (DNIT, 2006; NORMA DNIT-005, 2003)}

É a formação de uma película ou filme de material betuminoso na superfície do pavimento e se caracteriza por manchas em variadas dimensões. O ligante em excesso surge na superfície do pavimento migrando através do revestimento.

Pode ocorrer por:

$\checkmark$ excesso de material utilizado na imprimação ou impermeabilização;

$\checkmark$ dosagem inadequada da mistura asfáltica, acarretando teor excessivo de ligante ou índice de vazio muito baixo;

$\checkmark$ temperatura do ligante acima da especificada no momento da mistura.

Esse defeito pode-se manifestar em qualquer local do pavimento, mas surge, preferencialmente, nas trilhas de roda.

\subsubsection{6 - Comentários}

Analisando todas as definições, juntamente com os comentários parciais feitos em relação às mesmas, é possível concluir que as classificações dos defeitos, do modo como são apresentadas no Manual do DNIT, podem trazer dificuldades no momento das tomadas de decisões, pelo fato de apresentarem contradições entre si. 
Daí a constatação da necessidade de maior clareza no momento de definir e detalhar cada defeito, assim como o quanto o pavimento pode estar afetado pelo mesmo. Somente com essa clareza, a Gerência de Pavimentos poderá ser uma ferramenta eficaz e simplificadora do trabalho dos técnicos rodoviários.

No intuito de facilitar a visualização dos defeitos encontrados nos pavimentos, sob a visão dos três países, foi elaborada a Tabela Comparativa apresentada nas páginas de 45 a 52.

No capítulo 3, em sequência ao quadro comparativo, são tratadas as Avaliações dos Defeitos, sob a visão dos três países, Estados Unidos, França e Brasil. Do mesmo modo como a classificação diferenciada apresenta algumas inconsistências, as avaliações também são questionadas em sua maior ou menor aplicabilidade na Gerência de Pavimentos no Brasil. 
Tabela 2 - Comparação entre as Classificações dos Estados Unidos, da França e do Brasil

\begin{tabular}{|c|c|c|c|c|c|}
\hline Defeitos & $\begin{array}{l}\text { Normas EUA (Obs 1) } \\
\text { (aparência / causa) }\end{array}$ & $\begin{array}{c}\text { Normas EUA } \\
\text { (Obs 1) (severidade) }\end{array}$ & $\begin{array}{c}\text { Normas EUA } \\
\text { (Obs 1) (medição / } \\
\text { reparo) }\end{array}$ & $\begin{array}{l}\text { Normas Francesas } \\
\text { - LCPC, Método } \\
\text { Vizir (Obs 5) }\end{array}$ & $\begin{array}{c}\text { Normas Brasileiras (Manual } \\
\text { do DNIT, Norma DNIT } 005 \text { / } \\
2003 \text { - TER) }\end{array}$ \\
\hline Fissura & Nada consta & Nada consta & Nada consta & Nada consta & $\begin{array}{l}\text { Abertura visível a olho nu }<1,50 \mathrm{~m} . \mathrm{Se} \\
\text { for }>1,50 \mathrm{~m} \text { é a Trinca. }(\mathrm{Obs} 3)\end{array}$ \\
\hline $\begin{array}{l}\text { Trinca por } \\
\text { Fadiga }\end{array}$ & $\begin{array}{l}\text { Blocos irregulares tipo couro de } \\
\text { jacaré, espaçamento < } 0.3 \text { m, } \\
\text { surgem na 'trilha de roda'. } \\
\text { Causas: pavimento submetido a } \\
\text { repetidas aplicações de cargas } \\
\text { (tráfego rodoviário) ou com } \\
\text { cargas acima da capacidade } \\
\text { estrutural chega ao limite, } \\
\text { construção com espessura } \\
\text { inferior à necessária ou sem } \\
\text { controle de qualidade adequado } \\
\text { ou chuvas conduzidas de modo } \\
\text { inadequado enfraquecem a } \\
\text { estrutura do pavimento. }\end{array}$ & $\begin{array}{l}\text { Baixa (desconectadas ou } \\
\text { conectadas levemente, } \\
\text { sem bombeamento, sem } \\
\text { erosão nos bordos), } \\
\text { Moderada (conexões com } \\
\text { padrão definido, talvez } \\
\text { desgaste e selamento, } \\
\text { erosão de bordos, sem } \\
\text { bombeamento), Alta } \\
\text { (padrão evidente, com } \\
\text { selamento e desgaste } \\
\text { acentuado, com erosão } \\
\text { acentuada nos bordos, } \\
\text { pedaços retirados pelo } \\
\text { tráfego, com } \\
\text { bombeamento). }\end{array}$ & $\begin{array}{l}\text { Mede-se área de } \\
\text { ocorrência de cada nível } \\
\text { de severidade. Reparo é } \\
\text { tratamento superficial ou } \\
\text { lama asfáltica } \\
\text { (temporário), ou remendo } \\
\text { (permanente). Ou } \\
\text { recapeamento. Ou } \\
\text { reconstrução do } \\
\text { pavimento. }\end{array}$ & $\begin{array}{l}\text { Fissuras na superfície } \\
\text { (trilhas de roda). Evolui } \\
\text { para aspecto de couro } \\
\text { de jacaré ou crocodilo. } \\
\text { Surge por ação contínua } \\
\text { do tráfego viário (sob } \\
\text { cargas repetidas). } \\
\text { Enquadra-se ainda um } \\
\text { tipo de trinca circular } \\
\text { (“faiençage circulaire”) } \\
\text { que leva à ocorrência da } \\
\text { trinca por fadiga. } \\
\text { DEFEITO } \\
\text { ESTRUTURAL }\end{array}$ & $\begin{array}{l}\text { Trincamento: fendas, fissuras, trincas } \\
\text { isoladas longitudinais ou transversais, } \\
\text { trincas interligadas (couro de jacaré) ou } \\
\text { bloco. Classificação: FC-1 / FC-2 / FC- } \\
3 \text { (1 - } 2 \text { - } 3 \text { consideram o aumento de } \\
\text { gravidade). Causas: tráfego atuante, por } \\
\text { carregamento e alívio, promove tensões } \\
\text { de tração na fibra interior do } \\
\text { revestimento; alternância na mudança } \\
\text { diária de temperatura que acusa } \\
\text { contrações do revestimento; reflexão de } \\
\text { trincas existentes em bases cimentadas. } \\
\text { Há subdivisão: fadiga (alívio e } \\
\text { carregamento), envelhecimento } \\
\text { (endurecimento do asfalto e perda de } \\
\text { flexibilidade do ligante), reflexão. } \\
\text { (Obs 2) }\end{array}$ \\
\hline $\begin{array}{l}\text { Trinca em } \\
\text { Blocos }\end{array}$ & $\begin{array}{l}\text { Blocos em forma de retângulos } \\
\text { conectados }\left(0,1 \text { a } 10 \mathrm{~m}^{2}\right) \text {. } \\
\text { Causas: contrações na mistura } \\
\text { além da capacidade de origem } \\
\text { térmica (camadas superficiais } \\
\text { com revestimento de misturas } \\
\text { asfálticas com agregados finos e } \\
\text { asfalto com baixa penetração), } \\
\text { contrações por variação no teor } \\
\text { de umidade (camadas } \\
\text { inferiores), perda de elasticidade } \\
\text { por tempo de mistura incorreto } \\
\text { ou misturas com temperaturas } \\
\text { excessivas ou estocagem com } \\
\text { tempo incorreto, base com } \\
\text { cimento ou com solos tropicais. }\end{array}$ & $\begin{array}{l}\text { Baixa (até } 6 \mathrm{~mm} \text { ou } \\
\text { trincas seladas com } \\
\text { dimensões indefinidas), } \\
\text { Moderada (entre } 6 \text { e } 19 \\
\text { mm ou trincas com menos } \\
\text { de } 19 \text { mm somadas a } \\
\text { grande número de trincas } \\
\text { com baixa severidade), } \\
\text { Alta (acima de } 19 \text { mm ou } \\
\text { grande número de trincas } \\
\text { com menos de } 19 \text { mm } \\
\text { somadas a um número } \\
\text { significativo de trincas } \\
\text { com moderada a alta } \\
\text { severidade). }\end{array}$ & $\begin{array}{l}\text { Mede-se a área de } \\
\text { ocorrência de cada nível } \\
\text { de severidade e a área } \\
\text { padrão dos blocos por } \\
\text { trecho. Para pontos com } \\
\text { dimensões e } \\
\text { profundidades reduzidas } \\
\text { usa-se material selante } \\
\text { (emulsão asfáltica, } \\
\text { tratamento superficial, } \\
\text { lama asfáltica). Para } \\
\text { pontos de maior } \\
\text { severidade faz-se: } \\
\text { remendo, reciclagem, } \\
\text { recapeamento ou } \\
\text { reconstrução. }\end{array}$ & $\begin{array}{l}\text { Surgem por contrações } \\
\text { após a aplicação da } \\
\text { mistura asfáltica. }\end{array}$ & $\begin{array}{l}\text { E somente citada no item Trincamento } \\
\text { (indicado no item Trinca por Fadiga } \\
\text { deste quadro) no Manual do DNIT. } \\
\text { Na Norma DNIT - } 005 \text { esse defeito é } \\
\text { descrito como sendo um conjunto de } \\
\text { trincas interligadas caracterizadas pela } \\
\text { configuração de blocos com lados bem } \\
\text { definidos, com ou sem erosão nas } \\
\text { bordas. }\end{array}$ \\
\hline
\end{tabular}




\begin{tabular}{|c|c|c|c|c|c|}
\hline $\begin{array}{l}\text { Trinca nos } \\
\text { Bordos }\end{array}$ & $\begin{array}{l}\text { Em acostamentos sem } \\
\text { pavimentação, no limite com } \\
\text { acostamento, } 60 \mathrm{~cm} \text { da } \\
\text { extremidade do pavimento, com } \\
\text { tamanhos irregulares e } \\
\text { crescentes ou regulares; surge } \\
\text { por compactação insuficiente ou } \\
\text { drenagem deficiente. }\end{array}$ & $\begin{array}{l}\text { Baixa (sem rupturas ou } \\
\text { perda de material), } \\
\text { Moderada (com algumas } \\
\text { rupturas e perda de até } \\
10 \% \text { do pavimento), Alta } \\
\text { (trincas com rupturas e } \\
\text { perda de mais de } 10 \% \text { ). }\end{array}$ & $\begin{array}{l}\text { Mede-se a extensão do } \\
\text { pavimento afetado, por } \\
\text { severidade. Para reparo, } \\
\text { usa-se selante (para evitar } \\
\text { a entrada de água). Se for } \\
\text { o caso de drenagem } \\
\text { deficiente, corrige-se } \\
\text { (talvez remendo). }\end{array}$ & $\begin{array}{l}\text { No limite com o } \\
\text { acostamento sem } \\
\text { pavimento. Ocorre por } \\
\text { espessura inadequada } \\
\text { das camadas do } \\
\text { pavimento; má } \\
\text { compactação; } \\
\text { problemas com } \\
\text { drenagem; situações de } \\
\text { clima ou de vegetação. }\end{array}$ & $\begin{array}{l}\text { E citada no Manual do DNIT a } \\
\text { possibilidade de haver trincas } \\
\text { longitudinais na borda do pavimento } \\
\text { causadas por umidade. }\end{array}$ \\
\hline $\begin{array}{c}\text { Trincas } \\
\text { Longitudinais }\end{array}$ & $\begin{array}{l}\text { Paralelas ao eixo. Dentro ou fora } \\
\text { das trilhas de rodas. Facilita a } \\
\text { penetração de água e provoca } \\
\text { instabilidade entre as camadas } \\
\text { do pavimento, e as trincas por } \\
\text { fadiga ou o desgaste. Se fora das } \\
\text { trilhas de roda, deve-se a } \\
\text { adensamento insuficiente ou } \\
\text { feito de maneira diferenciada na } \\
\text { execução do pavimento. Se no } \\
\text { limite das trilhas de roda, deve- } \\
\text { se a excesso de carga. Pode } \\
\text { surgir por misturas com } \\
\text { temperaturas muito quentes } \\
\text { aplicadas sobre base frágil. }\end{array}$ & Idem a trincas em bloco. & $\begin{array}{l}\text { Mede-se extensão, por } \\
\text { severidade, tanto nas que } \\
\text { estão nas trilhas de roda } \\
\text { como nas que estão fora } \\
\text { das trilhas de roda. Mede- } \\
\text { se extensão de trincas } \\
\text { seladas com bom selante. } \\
\text { Trincas menores de } 3 \mathrm{~mm} \\
\text { não são reparadas. Para } \\
\text { trincas de } 3 \text { a } 20 \text { mm usa- } \\
\text { se selante. Para trincas } \\
\text { acima de } 20 \text { mm faz-se } \\
\text { remendo, recapeamento } \\
\text { ou reconstrução. }\end{array}$ & $\begin{array}{l}\text { Resulta de imperfeição } \\
\text { na colagem de faixas } \\
\text { contíguas de pré- } \\
\text { misturado. Não aparece } \\
\text { sempre na trilha de } \\
\text { roda. Onde a trinca } \\
\text { longitudinal aparece na } \\
\text { trilha de roda, pode } \\
\text { haver defeito tipo } \\
\text { 'degradação estrutural'. } \\
\text { DEFEITO } \\
\text { ESTRUTURAL SE } \\
\text { NA TRILHA DE } \\
\text { RODA }\end{array}$ & $\begin{array}{l}\text { Manual DNIT descreve trincamento } \\
\text { devido à variação brusca de } \\
\text { temperatura que causa retração térmica, } \\
\text { principalmente no caso de ligante com } \\
\text { alta rigidez. Pode haver retração em } \\
\text { bases cimentadas. Depende das } \\
\text { variações de temperatura e das } \\
\text { propriedades dos materiais da mistura } \\
\text { (não separa trinca longitudinal da } \\
\text { transversal). DNIT } 005 \text { detalha apenas } \\
\text { que se trata de trinca isolada com } \\
\text { direção paralela ao eixo da via. Até } 100 \\
\text { cm é chamada trinca longitudinal curta. } \\
\text { Acima de } 100 \mathrm{~cm} \text { é chamada trinca } \\
\text { longitudinal longa. (Obs } 8 \text { ) }\end{array}$ \\
\hline $\begin{array}{l}\text { Trincas por } \\
\text { Reflexão em } \\
\text { Juntas }\end{array}$ & $\begin{array}{l}\text { Depende da trinca de origem. } \\
\text { Ocorre por descontinuidades nas } \\
\text { camadas inferiores, que se } \\
\text { propagam através do } \\
\text { revestimento. Surge por: trincas } \\
\text { ou juntas nas camadas inferiores } \\
\text { de pavimento rígido, } \\
\text { movimentação de bases (tratadas } \\
\text { com cimento ou cal, ou de solos } \\
\text { arenosos finos lateríticos), } \\
\text { trincas por baixa temperatura (ou } \\
\text { trincas em blocos ou } \\
\text { longitudinais ou por fadiga) nas } \\
\text { camadas antigas superficiais. }\end{array}$ & Idem a trincas em bloco. & $\begin{array}{l}\text { Medem-se como } \\
\text { longitudinais (extensão) } \\
\text { ou transversais (extensão } \\
\text { e quantia), por nível. Ou } \\
\text { como em bloco, ou por } \\
\text { fadiga. Mede-se extensão } \\
\text { das seladas. Fazer: lama } \\
\text { asfáltica ou tratamento } \\
\text { superficial, recapeamento } \\
\text { ou reconstrução. Para } \\
\text { evitar propagação, utiliza- } \\
\text { se geomembrana, } \\
\text { reciclagem, outras. }\end{array}$ & Nada consta & $\begin{array}{l}\text { No item Trincamento do Manual do } \\
\text { DNIT é citado que pode ocorrer um } \\
\text { tipo de trinca por reflexão quando } \\
\text { existe algum problema de trinca } \\
\text { (interligada ou isolada) nas camadas } \\
\text { inferiores e esse problema propaga-se } \\
\text { nas camadas superiores. }\end{array}$ \\
\hline
\end{tabular}




\begin{tabular}{|c|c|c|c|c|c|}
\hline $\begin{array}{c}\text { Trincas } \\
\text { Transversais }\end{array}$ & $\begin{array}{l}\text { São perpendiculares ao eixo da } \\
\text { via. Ocorrem devido a } \\
\text { contrações térmicas do } \\
\text { revestimento e infiltração de } \\
\text { água nas camadas inferiores. }\end{array}$ & Idem a trincas em bloco & $\begin{array}{l}\text { Mede-se quantia e } \\
\text { extensão por severidade, e } \\
\text { extensões de trincas } \\
\text { seladas por severidade. } \\
\text { Menor severidade: } \\
\text { material selante. Maior } \\
\text { severidade: remendo, } \\
\text { reciclagem, recapeamento } \\
\text { ou reconstrução. }\end{array}$ & $\begin{array}{l}\text { Ocorre por: variação de } \\
\text { temperatura (comum } \\
\text { em países de climas } \\
\text { frios) ou degradação de } \\
\text { pavimentos de } \\
\text { agregados lateríticos } \\
\text { com limite de retração } \\
\text { particular (variação do } \\
\text { teor de água na fração } \\
\text { argilosa). }\end{array}$ & $\begin{array}{l}\text { Ver comentários das considerações } \\
\text { sobre trincas longitudinais (anteriores), } \\
\text { no caso do Manual do DNIT. A Norma } \\
\text { DNIT } 005 \text { detalha apenas que se trata } \\
\text { de trinca isolada com direção ortogonal } \\
\text { ao eixo da via. Se tiver extensão de até } \\
100 \text { cm é chamada trinca transversal } \\
\text { curta. Se tiver extensão acima de } 100 \\
\text { cm é chamada trinca transversal longa. } \\
\text { (Obs 8) }\end{array}$ \\
\hline Remendos & $\begin{array}{l}\text { É uma conservação da } \\
\text { superfície. É o preenchimento de } \\
\text { panelas ou de qualquer outro } \\
\text { orifício ou depressão com massa } \\
\text { asfáltica. Porção de pavimento } \\
\text { superficial, maior que } 0.1 \mathrm{~m}^{2} \text {, que } \\
\text { é removida e substituída por } \\
\text { material aplicado sobre } \\
\text { construção original da via. } \\
\text { Vários defeitos causam } \\
\text { necessidade de remendos. }\end{array}$ & $\begin{array}{l}\text { Baixa (<6 mm pouco } \\
\text { afetando o tráfego), } \\
\text { Moderada (entre } 6 \mathrm{e} \\
12 \mathrm{~mm} \text { afetando } \\
\text { moderadamente o } \\
\text { tráfego), Alta (> } 12 \mathrm{~mm} \mathrm{e} \\
\text { com bombeamento } \\
\text { ocasional e com grave } \\
\text { interferência no tráfego). } \\
\text { Mede-se por severidade. }\end{array}$ & $\begin{array}{l}\text { Registram-se as } \\
\text { ocorrências e a área } \\
\text { afetada por severidade. É } \\
\text { feito recorte e limpeza da } \\
\text { área, aplicação da camada } \\
\text { impermeabilizante e } \\
\text { aderente e do material de } \\
\text { reposição. Se o material é } \\
\text { aplicado sem recorte da } \\
\text { área o nome é tapa- } \\
\text { buraco. }\end{array}$ & $\begin{array}{l}\text { E efetuado para } \\
\text { regularizar o } \\
\text { pavimento, quando } \\
\text { ocorrem defeitos } \\
\text { superficiais ou } \\
\text { profundos. Caso sejam } \\
\text { frequentes no local, } \\
\text { talvez ainda haja } \\
\text { problema. } \\
\text { DEFEITO } \\
\text { ESTRUTURAL - SE } \\
\text { NÃO CORRIGE } \\
\text { TOTALMENTE }\end{array}$ & $\begin{array}{l}\text { Define-se como uma porção do } \\
\text { pavimento onde o material original foi } \\
\text { removido e substituído por outro } \\
\text { (similar ou diferente). Seu surgimento } \\
\text { vem de problemas estruturais ou } \\
\text { superficiais do pavimento. Podem } \\
\text { ocorrer por diversos motivos, em geral } \\
\text { oriundos de ação conjunta de tráfego e } \\
\text { condições ambientais. Pode ser } \\
\text { profundo (substitui-se o revestimento e } \\
\text { uma ou mais camadas inferiores) ou } \\
\text { superficial (correção da superfície do } \\
\text { revestimento). }\end{array}$ \\
\hline $\begin{array}{c}\text { Panelas ou } \\
\text { Buracos }\end{array}$ & $\begin{array}{l}\text { Cavidade (como 'tigela') que } \\
\text { surge no revestimento, podendo } \\
\text { ou não atingir camadas } \\
\text { subjacentes. Resulta de } \\
\text { desintegração local, sob a ação } \\
\text { do tráfego e da água; com } \\
\text { fragmentação e remoção do } \\
\text { pavimento, após trincas por } \\
\text { fadiga ou desgaste. Surge em } \\
\text { revestimentos com pouca } \\
\text { espessura ou baixa capacidade } \\
\text { de suporte (falha estrutural). } \\
\text { Pode aparecer em locais com } \\
\text { segregação de material (falta de } \\
\text { ligante) ou com problemas de } \\
\text { drenagem. }\end{array}$ & $\begin{array}{l}\text { Baixa (até } 25 \mathrm{~mm} \text { de } \\
\text { profundidade), Moderada } \\
\text { (de } 25 \text { a } 50 \mathrm{~mm} \text { de } \\
\text { profundidade), Alta } \\
\text { (acima de } 50 \mathrm{~mm} \text { de } \\
\text { profundidade). }\end{array}$ & $\begin{array}{l}\text { Deve ser registrada a } \\
\text { quantidade de ocorrência } \\
\text { e a área afetada relativa } \\
\text { por nível de severidade. O } \\
\text { reparo deve ser feito com } \\
\text { remendo, seguido de } \\
\text { recapeamento se for o } \\
\text { caso, dependendo do } \\
\text { tamanho da área } \\
\text { comprometida. }\end{array}$ & $\begin{array}{l}\text { Aparece em decorrência } \\
\text { do desgaste ou da } \\
\text { destruição da camada } \\
\text { de rolamento. No } \\
\text { início, suas dimensões } \\
\text { são reduzidas. Caso não } \\
\text { seja corrigido, suas } \\
\text { dimensões podem } \\
\text { aumentar, levando à } \\
\text { remoção do pavimento. } \\
\text { Inicia-se no } \\
\text { revestimento, mas pode } \\
\text { atingir a base se não for } \\
\text { reparado. }\end{array}$ & $\begin{array}{l}\text { Cavidades formadas no revestimento } \\
\text { do pavimento e com dimensões e } \\
\text { profundidades variadas. Afeta } \\
\text { estruturalmente o pavimento, } \\
\text { permitindo o acesso das águas } \\
\text { superficiais ao interior da estrutura. } \\
\text { Afetam a irregularidade longitudinal e, } \\
\text { como consequência, a segurança do } \\
\text { tráfego e o custo do transporte. As } \\
\text { causas podem ser: trincamento por } \\
\text { fadiga (estágio terminal); desintegração } \\
\text { localizada na superfície do pavimento } \\
\text { (desgaste de alta severidade). O } \\
\text { processo pode ser acelerado pelo } \\
\text { tráfego e pelo clima. }\end{array}$ \\
\hline
\end{tabular}




\begin{tabular}{|c|c|c|c|c|c|}
\hline $\begin{array}{l}\text { Deformação } \\
\text { Permanente }\end{array}$ & $\begin{array}{l}\text { Surge no caminho das 'trilhas de } \\
\text { rodas'. É um afundamento } \\
\text { longitudinal que acompanha o } \\
\text { trajeto percorrido pelas rodas } \\
\text { dos veículos. Ocorre devido à } \\
\text { densificação dos materiais ou à } \\
\text { ruptura por cisalhamento. } \\
\text { Causas: dimensionamento } \\
\text { inadequado das espessuras das } \\
\text { camadas, dosagem inadequada } \\
\text { da mistura asfáltica, } \\
\text { compactação inadequada e } \\
\text { posterior consolidação pela ação } \\
\text { do tráfego, falha na drenagem. } \\
\text { Se houve ruptura por } \\
\text { cisalhamento podem surgir } \\
\text { elevações laterais paralelas ao } \\
\text { tráfego. }\end{array}$ & $\begin{array}{l}\text { Baixa (até } 25 \mathrm{~mm} \text { de } \\
\text { profundidade), Moderada } \\
\text { (de } 25 \text { a } 50 \mathrm{~mm} \text { de } \\
\text { profundidade), Alta } \\
\text { (acima de } 50 \mathrm{~mm} \text { de } \\
\text { profundidade). } \\
\text { **SEPARAÇÃO PELA } \\
\text { NORMA FRANCESA } \\
\text { (semelhante e citada para } \\
\text { comparação) } \\
\text { A gravidade varia entre } \\
\text { fraca (até } 2 \mathrm{~cm} \text { de altura), } \\
\text { média ( } 2 \text { a } 4 \mathrm{~cm} \text { de } \\
\text { altura), forte (acima de). } \\
4 \mathrm{~cm}) .\end{array}$ & $\begin{array}{l}\text { Devem ser anotadas } \\
\text { medições do desnível ou } \\
\text { profundidades máximas } \\
\text { das deformações, em } \\
\text { milímetros, a cada 20m } \\
\text { (metros) de intervalo. } \\
\text { Para reparar esse defeito } \\
\text { utiliza-se: reciclagem, } \\
\text { recapeamento ou } \\
\text { reconstrução total do } \\
\text { pavimento. }\end{array}$ & $\begin{array}{l}\text { Surge a } 50 \text { - } 80 \mathrm{~cm} \text { do } \\
\text { bordo devido a: suporte } \\
\text { insuficiente (ou baixa } \\
\text { capacidade) ou com má } \\
\text { qualidade, deficiência } \\
\text { de drenagem (varia com } \\
\text { a base), recalque dos } \\
\text { materiais sob tráfego } \\
\text { pesado e canalizado } \\
\text { associado ou não à } \\
\text { queda de resistência das } \\
\text { camadas inferiores. } \\
\text { Existe 'afundamento } \\
\text { localizado ou pontual' } \\
\text { ("affaissement hors } \\
\text { rive" ou "flache"), com } \\
\text { igual origem, mas } \\
\text { pequena área. } \\
\text { DEFEITO } \\
\text { ESTRUTURAL }\end{array}$ & $\begin{array}{l}\text { E uma depressão na superfície do } \\
\text { pavimento, com ou sem solevamento, } \\
\text { se apresentando sob a forma de: } \\
\text { - afundamento plástico (com } \\
\text { solevamento) causado pela fluência } \\
\text { plástica de uma ou mais camadas do } \\
\text { pavimento ou do subleito (extensão de } \\
\text { até } 6 \text { m é plástico local ou superior a } 6 \\
\text { m e na trilha de roda é plástico de trilha } \\
\text { de roda); } \\
\text { - afundamento de consolidação (sem } \\
\text { solevamento) causado por consolidação } \\
\text { diferencial de uma ou mais camadas de } \\
\text { pavimento ou do subleito (extensão de } \\
\text { até } 6 \text { m é consolidação local ou } \\
\text { superior a } 6 \text { m e na trilha de roda é } \\
\text { consolidação de trilha de roda). } \\
\text { (Obs } 8 \text { ) }\end{array}$ \\
\hline $\begin{array}{c}\text { Ondulação } \\
\text { ou } \\
\text { Corrugação } \\
\text { ou } \\
\text { Escorregamento }\end{array}$ & $\begin{array}{l}\text { Deslocamento longitudinal do } \\
\text { pavimento, ocasionando } \\
\text { ondulações transversais. É } \\
\text { causado por movimento de } \\
\text { 'frenagem' ou 'aceleração'. } \\
\text { Surge por: dosagem inadequada } \\
\text { da mistura asfáltica, fraca } \\
\text { ligação entre base e } \\
\text { revestimento, estrutura } \\
\text { insuficiente. Localiza-se em } \\
\text { curvas, interseç̧ões, aclives ou } \\
\text { declives. } \\
\text { (Obs 4) }\end{array}$ & $\begin{array}{l}\text { Os níveis de severidade } \\
\text { podem ser determinados } \\
\text { em função do quanto a } \\
\text { qualidade do tráfego é } \\
\text { afetada. }\end{array}$ & $\begin{array}{l}\text { A medição é efetuada } \\
\text { através do registro da } \\
\text { quantia de ocorrências e } \\
\text { da área afetada }\left(\mathrm{em} \mathrm{m}^{2}\right) \text {. } \\
\text { Devem ser efetuados: } \\
\text { remendos, reciclagem, } \\
\text { recapeamento ou } \\
\text { reconstrução. }\end{array}$ & $\begin{array}{l}\text { Ocorre quando há forte } \\
\text { solicitação do } \\
\text { pavimento (+ em curvas } \\
\text { ou rampas ou locais } \\
\text { sujeitos a frenagem e } \\
\text { acelerações). Nesta } \\
\text { classificação podem-se } \\
\text { enquadrar defeitos } \\
\text { pontuais ("gonfle"), } \\
\text { nem sempre em locais } \\
\text { com acelerações e } \\
\text { frenagens, mas com } \\
\text { características } \\
\text { semelhantes ('estufa- } \\
\text { mento' no pavimento). } \\
\text { Surge por } \\
\text { incompatibilidades } \\
\text { químicas ou má } \\
\text { compactação. }\end{array}$ & $\begin{array}{l}\text { Ondulação ou corrugação: ondulações } \\
\text { transversais (permanentes), no } \\
\text { revestimento. Causas: instabilidade na } \\
\text { mistura asfáltica do revestimento ou da } \\
\text { base; umidade nas camadas } \\
\text { subjacentes; contaminação da mistura } \\
\text { por materiais estranhos; retenção de } \\
\text { água na mistura. Ocorre com } \\
\text { acelerações e frenagens. } \\
\text { Escorregamento: movimento horizontal } \\
\text { do revestimento, por esforços } \\
\text { tangenciais transmitidos por eixos dos } \\
\text { veículos; produz ondulação curta e } \\
\text { abrupta no pavimento (como meia lua). } \\
\text { Causas: ligação inadequada entre } \\
\text { revestimento e camada subjacente; } \\
\text { inércia limitada do revestimento por } \\
\text { espessura reduzida; compactação } \\
\text { deficiente; fluência plástica por }\end{array}$ \\
\hline
\end{tabular}




\begin{tabular}{|c|c|c|c|c|c|}
\hline & & & & & $\begin{array}{l}\text { temperaturas elevadas. Surge com } \\
\text { acelerações e frenagens (aclives e } \\
\text { declives, curvas de raio pequeno, } \\
\text { interseções e paradas de ônibus ou } \\
\text { obstáculos). (Obs 7) }\end{array}$ \\
\hline Exsudação & $\begin{array}{l}\text { Excesso de material betuminoso } \\
\text { na superfície, usualmente na } \\
\text { trilha de roda. Apresenta-se } \\
\text { como asfalto com perda da } \\
\text { coloração normal ou perda da } \\
\text { textura comum. O agregado } \\
\text { mostra excesso de material } \\
\text { betuminoso (cor mais escura). A } \\
\text { superfície é brilhante e pegajosa. } \\
\text { Surgem marcas de pneus com } \\
\text { temperaturas altas e redução do } \\
\text { atrito pneu-pavimento. Resulta } \\
\text { de mistura asfáltica inadequada } \\
\text { (baixo índice de vazios). }\end{array}$ & $\begin{array}{l}\text { Classifica-se de acordo } \\
\text { com a situação ou com a } \\
\text { evolução do problema. } \\
\text { Baixa: há alteração na } \\
\text { coloração de trechos de } \\
\text { pavimento em relação ao } \\
\text { geral. Moderada: ocorre } \\
\text { alteração da textura do } \\
\text { pavimento. Alta: o } \\
\text { pavimento apresenta } \\
\text { aspecto brilhante e } \\
\text { aparecem marcas de pneu } \\
\text { no mesmo (em tempo } \\
\text { quente). }\end{array}$ & $\begin{array}{l}\text { Para quantificar esse tipo } \\
\text { de defeito é verificada a } \\
\text { área de ocorrência, } \\
\text { classificada por nível de } \\
\text { severidade. Deve ser } \\
\text { reparado com tratamento } \\
\text { superficial ou areia } \\
\text { quente, ou mesmo } \\
\text { reciclagem. }\end{array}$ & $\begin{array}{l}\text { O excesso de ligante } \\
\text { surge na superfície. }\end{array}$ & $\begin{array}{l}\text { E a formação de uma película ou filme } \\
\text { de material betuminoso na superfície } \\
\text { do pavimento e se caracteriza por } \\
\text { manchas em variadas dimensões. } \\
\text { Ocorre por: dosagem inadequada da } \\
\text { mistura asfáltica que acarreta teor } \\
\text { excessivo de ligante ou índice de vazios } \\
\text { muito baixo, temperatura do ligante } \\
\text { acima da especificada no momento da } \\
\text { mistura. Pode-se manifestar em } \\
\text { qualquer local do pavimento, mas } \\
\text { surge, preferencialmente, nas trilhas de } \\
\text { roda. }\end{array}$ \\
\hline $\begin{array}{l}\text { Agregados } \\
\text { Polidos } \\
\text { (Obs 4) }\end{array}$ & $\begin{array}{l}\text { Polimento ou desgaste dos } \\
\text { agregados e do ligante } \\
\text { betuminoso pode expor o } \\
\text { agregado graúdo. Pode ocorrer } \\
\text { perda de material. Esse defeito } \\
\text { pode ser resultado da ação } \\
\text { abrasiva do tráfego, que elimina } \\
\text { asperezas e angularidades das } \\
\text { partículas. }\end{array}$ & $\begin{array}{l}\text { Não há como definir } \\
\text { níveis de severidade. O } \\
\text { grau de polimento pode } \\
\text { refletir em redução do } \\
\text { atrito pneu-pavimento e } \\
\text { ocasionar } \\
\text { comprometimento da } \\
\text { segurança viária. }\end{array}$ & $\begin{array}{l}\text { Avaliam-se as áreas } \\
\text { atingidas em } \mathrm{m}^{2} \text {. Deve ser } \\
\text { executado tratamento } \\
\text { superficial ou lama } \\
\text { asfáltica. Ou reciclagem, } \\
\text { recapeamento, } \\
\text { reconstrução do } \\
\text { pavimento. }\end{array}$ & Nada consta. & Nada consta. \\
\hline Desgaste & $\begin{array}{l}\text { Surge por deslocamento de } \\
\text { partículas de agregados e perda } \\
\text { de adesividade do ligante. Evolui } \\
\text { de perda de finos para perda de } \\
\text { algum agregado graúdo, e, } \\
\text { enfim, para perdas maiores de } \\
\text { agregado. Causas: } \\
\text { envelhecimento, endurecimento, } \\
\text { oxidação, volatilização, } \\
\text { intemperização. Para propiciar } \\
\text { boa adesividade entre agregado e }\end{array}$ & $\begin{array}{l}\text { Podem ser classificados } \\
\text { de acordo com a situação } \\
\text { local ou com a evolução } \\
\text { do problema. Nível Baixo } \\
\text { é quando há perda de } \\
\text { agregados miúdos. Nível } \\
\text { Moderado é quando a } \\
\text { textura superficial torna- } \\
\text { se mais áspera e ocorre } \\
\text { perda de alguns agregados } \\
\text { graúdos. Nível Alto é }\end{array}$ & $\begin{array}{l}\text { A medição é feita com a } \\
\text { quantificação da área de } \\
\text { ocorrência, classificada } \\
\text { por nível de severidade. } \\
\text { Os reparos podem } \\
\text { compreender a execução } \\
\text { de: capa selante, } \\
\text { tratamento superficial ou } \\
\text { lama asfáltica, reciclagem } \\
\text { ou recapeamento. }\end{array}$ & $\begin{array}{l}\text { Inicialmente, ocorre } \\
\text { uma perda de material } \\
\text { reduzida. Com o passar } \\
\text { do tempo essa perda vai } \\
\text { se acelerando e } \\
\text { comprometendo a } \\
\text { qualidade do } \\
\text { pavimento. }\end{array}$ & $\begin{array}{l}\text { Perda de agregados ou argamassa fina } \\
\text { do revestimento. Apresenta aspereza } \\
\text { superficial anormal, perda do } \\
\text { envolvimento betuminoso e } \\
\text { arrancamento gradual de agregados. } \\
\text { Causas: redução da adesividade entre } \\
\text { agregado e ligante (por oxidação do } \\
\text { ligante + ação combinada de tráfego e } \\
\text { agentes intempéricos, por presença de } \\
\text { poeira ou sujeira na construção), } \\
\text { execução da obra em condições }\end{array}$ \\
\hline
\end{tabular}




\begin{tabular}{|c|c|c|c|c|c|}
\hline & $\begin{array}{l}\text { ligante, evitando a probabilidade } \\
\text { de ocorrência do desgaste } \\
\text { precoce, deve-se efetuar: } \\
\text { adequada mistura asfáltica } \\
\text { (dosagem ou temperatura de } \\
\text { execução); aplicação da mesma } \\
\text { com boas condições } \\
\text { meteorológicas, correta } \\
\text { compactação e tempo adequado } \\
\text { para liberação ao tráfego. } \\
\text { (Obs 4) }\end{array}$ & $\begin{array}{l}\text { quando a textura } \\
\text { superficial torna-se muito } \\
\text { áspera e ocorre perda } \\
\text { mais intensa de agregados } \\
\text { graúdos. }\end{array}$ & & & $\begin{array}{l}\text { meteorológicas ruins, presença de água } \\
\text { no revestimento (sobrepressões } \\
\text { hidrostáticas podem provocar } \\
\text { descolamento da película betuminosa), } \\
\text { deficiência de ligante asfáltico } \\
\text { decorrente de entupimento dos bicos ou } \\
\text { má regulagem da barra espargidora. Por } \\
\text { esses motivos, o ligante asfáltico não } \\
\text { consegue promover a retenção dos } \\
\text { agregados que se soltam sob ação das } \\
\text { cargas de tráfego. (bem detalhado no } \\
\text { Manual do DNIT e complementa ao } \\
\text { que foi apresentado) }\end{array}$ \\
\hline $\begin{array}{l}\text { Desnível entre } \\
\text { Pista e } \\
\text { Acostamento }\end{array}$ & $\begin{array}{l}\text { Diferença de elevação entre a } \\
\text { pista e o acostamento. Resulta da } \\
\text { aplicação de diferentes camadas } \\
\text { de material (em algumas } \\
\text { ocasiões é aplicada uma } \\
\text { espessura maior na camada de } \\
\text { rolamento do que no } \\
\text { acostamento). Nos casos de } \\
\text { acostamento não pavimentado, } \\
\text { pode haver erosão no mesmo, } \\
\text { ocasionando o desnível entre o } \\
\text { acostamento e a pista de } \\
\text { rolamento. Pode haver } \\
\text { consolidação diferencial entre } \\
\text { pista e acostamento. }\end{array}$ & $\begin{array}{l}\text { Os níveis de severidade } \\
\text { não são aplicados neste } \\
\text { caso. }\end{array}$ & $\begin{array}{l}\text { São feitas medições do } \\
\text { desnível a cada } 20 \mathrm{~m} \\
\text { (metros) de intervalo. } \\
\text { Para reparar esse defeito, } \\
\text { o acostamento deverá ser } \\
\text { recomposto no local da } \\
\text { ocorrência. }\end{array}$ & $\begin{array}{l}\text { Com acostamento } \\
\text { pavimentado: desnível } \\
\text { entre o mesmo e a pista } \\
\text { e provoca degrau } \\
\text { perigoso. Com } \\
\text { acostamento sem } \\
\text { pavimento: erosão no } \\
\text { mesmo compromete a } \\
\text { segurança do tráfego } \\
\text { (pode chegar até a via). } \\
\text { A gravidade deste } \\
\text { defeito surge só aqui: } \\
\text { baixa - desnível de } 1 \text { a } 5 \\
\mathrm{~cm} \text {, média - desnível } 5 \\
\text { a } 10 \mathrm{~cm} \text {, alta - desnível } \\
>10 \mathrm{~cm} \text {. (Obs 5) }\end{array}$ & Nada consta. \\
\hline $\begin{array}{c}\text { Bombeamento } \\
\text { (Obs 4) }\end{array}$ & $\begin{array}{l}\text { Vazamento ou ejeção de água da } \\
\text { parte inferior do pavimento } \\
\text { através das trincas quando sob } \\
\text { ação do tráfego. Detecta-se pela } \\
\text { presença de 'finos' na superfície } \\
\text { (erodido das camadas de apoio } \\
\text { ou base). Ocorre se existe água } \\
\text { sob o revestimento (deficiência } \\
\text { de drenagem). }\end{array}$ & $\begin{array}{l}\text { É difícil definir níveis de } \\
\text { severidade, porque a } \\
\text { quantidade de água } \\
\text { bombeada pode variar de } \\
\text { acordo com as condições } \\
\text { de umidade. }\end{array}$ & $\begin{array}{l}\text { Registram-se o número de } \\
\text { ocorrências e a área } \\
\text { atingida. Caso tenha sido } \\
\text { comprometido, o } \\
\text { pavimento deve ser } \\
\text { recuperado. Para se evitar } \\
\text { nova ocorrência de } \\
\text { Bombeamento deve ser } \\
\text { corrigido o sistema de } \\
\text { drenagem no local. }\end{array}$ & Nada consta. & Nada consta. \\
\hline
\end{tabular}




\begin{tabular}{|c|c|c|c|c|c|}
\hline $\begin{array}{l}\text { Descascamento } \\
\quad(\text { Obs 6) }\end{array}$ & $\begin{array}{l}\text { Nada consta (incluir no item } \\
\text { buraco ou panela ainda que com } \\
\text { severidade baixa). }\end{array}$ & $\begin{array}{l}\text { Nada consta (incluir no } \\
\text { item buraco ou panela). }\end{array}$ & $\begin{array}{l}\text { Nada consta (incluir no } \\
\text { item buraco ou panela). }\end{array}$ & $\begin{array}{l}\text { Partes da camada de } \\
\text { rolamento soltam-se } \\
\text { (descolam) da base. }\end{array}$ & $\begin{array}{l}\text { Nada consta (incluir no item buraco ou } \\
\text { panela). }\end{array}$ \\
\hline $\begin{array}{l}\text { Penteadura } \\
\quad \text { (Obs 6) }\end{array}$ & $\begin{array}{l}\text { Nada consta (incluir no item } \\
\text { desgaste). }\end{array}$ & $\begin{array}{l}\text { Nada consta (incluir no } \\
\text { item desgaste). }\end{array}$ & $\begin{array}{l}\text { Nada consta (incluir no } \\
\text { item desgaste). }\end{array}$ & $\begin{array}{l}\text { Má execução da } \\
\text { camada asfáltica com } \\
\text { distribuição irregular do } \\
\text { ligante (falha do bico), } \\
\text { ou por distribuição } \\
\text { incorreta de agregados. }\end{array}$ & Nada consta (incluir no item desgaste). \\
\hline
\end{tabular}

Obs 1: Foram citadas as maneiras de se identificar os defeitos, suas possíveis causas, classificação por níveis de severidade (inclusive como quantificar essa severidade) de acordo com o FHWA (1993), complementadas com os trabalhos de Fernandes Jr. et al. (2003) e Haas et al. (1994). São descritos os níveis de severidade e a maneira de se medir cada defeito, apenas com relação a esses trabalhos, tendo em vista que os mesmos são descritos com maior precisão nestas bibliografias (termos como 'trincas claramente abertas' utilizados nas normas francesas podem dar margem a diversas interpretações). Os modos de reparar os pavimentos são semelhantes nos três países.

Obs 2: O Manual do DNIT não apresenta detalhamento do modo como se apresenta cada tipo de fenda ou fissura ou trinca e do que pode provocar cada ocorrência. Esse item do quadro aliou o Manual do DNIT (Trincamento) e a Norma DNIT 005 / 2003 - TER (item Trinca interligada tipo 'couro de jacaré'). Outros detalhamentos dos vários tipos de trincas são encontrados na Norma DNIT 005 / 2003 - TER e são citados em trincas tipo bloco, trinca longitudinal e trinca transversal. As trincas por reflexão e nos bordos são citadas superficialmente no Manual do DNIT. A trinca de retração (citada na DNIT 005 / 2003) não é citada considerando-se que pode estar dentro das classificações de trinca longitudinal ou de trinca transversal. É confusa a divisão em trincas: por fadiga, por envelhecimento e por reflexão, citada no final deste item, mudando, inclusive, conceitos já reconhecidos como adequados, o que já foi mencionado no item 2.4.3 (página 38).

Obs 3: Existe nas normas brasileiras uma subdivisão de Fendas (qualquer descontinuidade na superfície do pavimento) em Fissuras e Trincas. Foi citado 'Fissuras' como primeiro item no quadro. Como as Fissuras são defeitos apenas citados nas normas brasileiras e não exigem programação para reparação, não são consideradas para fins de gerência de pavimentos. 
Obs 4: É possível observar-se uma classificação pelas agências norte-americanas que se assemelha à corrugação, é o "slippage cracking" ou "trinca parabólica", que ocorre em áreas de aceleração dos veículos: ao acelerar, o veículo vai para frente e a força de atrito 'empurra' o pavimento para trás (ele escorrega). Dentro do conceito de 'desgaste', existe uma subdivisão em algumas agências norte-americanas que classifica dois tipos desse defeito. Um deles é o "stripping" que é um tipo de desgaste que ocorre se existe incompatibilidade de materiais e, sob ação da água, o desgaste se inicia (precocemente), outro é o "wear loss" que é um desalojamento de agregados em função de envelhecimento e perda de adesividade (ocorre com a idade do pavimento). Agregados polidos e bombeamento são mencionados somente nas normas dos EUA, entretanto é importante sua avaliação tendo em vista sua ocorrência constante nos pavimentos brasileiros.

Obs 5: As normas francesas não detalham causas, maneiras de medir e níveis de severidade de alguns defeitos. Somente estas normas citam níveis de severidade do Desnível entre pista e acostamento, devendo estes níveis ser considerados para uma futura classificação geral.

Obs 6: O Descascamento é indicado como defeito unicamente nas normas francesas, podendo ser incluído no defeito Buraco ou Panela. A Penteadura é indicada como defeito unicamente nas normas francesas, podendo ser incluído no defeito Desgaste.

Obs 7: Nas normas norte-americanas, é citado o defeito 'escorregamento' e o defeito 'corrugação' como sendo um único defeito a ser considerado. Nas normas francesas só é citado o defeito 'corrugação'. É possível se constatar que fica mais clara e coerente a classificação desses manuais ao invés da classificação do DNIT. Segundo a descrição desses defeitos pelo DNIT, a forma desses defeitos é pouco diferenciada e pouco visível na prática. As causas desses dois defeitos também são detalhadas de maneira mais simples nos outros manuais (norte-americano e francês), sendo as mesmas, no entender daqueles órgãos técnicos. Os locais onde esses defeitos surgem são também os mesmos.

Obs 8: É melhor e mais importante quantificar a extensão do que estabelecer limites para denominar-se o tipo de trinca, como é o caso do valor limite de $100 \mathrm{~cm}$ para uma trinca longitudinal ou transversal ser denominada de curta ou longa. O mesmo se aplica no caso da deformação permanente, que utiliza o valor limite de $6 \mathrm{~m}$ para a deformação ser chamada de local ou de trilha de roda. 


\section{CAPÍTULO 3}

\section{AVALIAÇÕES DE DEFEITOS EM PAVIMENTOS FLEXÍVEIS}

\subsection{Considerações Iniciais}

É importante que sejam considerados os aspectos tanto de conforto como de segurança, para que uma rodovia seja avaliada como sendo de boa qualidade ou não. Uma rodovia confortável e segura, consequentemente, será uma rodovia com tráfego mais econômico.

A avaliação dos defeitos que surgem nos pavimentos permite que sejam efetuados reparos nos mesmos a fim de que os usuários tenham a segurança e o conforto restabelecidos o mais rapidamente possível. Para que os reparos necessários sejam efetuados da maneira mais adequada e no momento correto, com a melhor aplicação dos recursos financeiros disponíveis, essa avaliação deverá ser a mais eficiente possível.

Assim pensando, foram desenvolvidos métodos de avaliação da faixa de rolamento tanto subjetivos como objetivos. A avaliação subjetiva baseia-se na opinião dos usuários sobre a via com relação ao conforto com que os motoristas trafegam pela mesma, identificando o quanto os motoristas estão satisfeitos ou insatisfeitos com o pavimento, através de atribuição de notas ou conceitos. Já a avaliação objetiva vai indicar o quanto a qualidade de rolamento e a segurança da via são prejudicadas pelas irregularidades do pavimento, e, para tanto, são efetuadas medições dessas irregularidades através de vários métodos. 


\subsection{Avaliações de Pavimentos Flexíveis nos Estados Unidos}

A avaliação de defeitos em pavimentos flexíveis nos Estados Unidos tem como referência inicial o AASHO (American Association of State Highway Officials) Road Test (CAREY e IRICK, 1960), onde foram efetuadas avaliações subjetivas e objetivas.

\subsection{1 - Avaliação Subjetiva}

Um bom nível de serviço de uma rodovia decorre de características que proporcionem um tráfego agradável, com conforto e segurança. As informações a respeito da situação atual da rodovia devem indicar qual é esse nível de serviço, no momento de suas avaliações, para que a tomada de decisões a respeito das intervenções na via seja efetuada de modo adequado.

Na ocasião do AASHO Road Test (1956-1961), foi desenvolvido o conceito de 'serventia', por Carey e Irick (1960). Esse conceito define que 'o nível de serventia é uma medida da capacidade da rodovia em servir ao tráfego naquele dado momento'. O nível de serventia vai diminuindo com o tempo ou idade útil da via (ou ambos) e, também, em decorrência do desgaste natural que o pavimento sofre com a ação do tráfego rodoviário. Essa variação é definida como desempenho do pavimento.

O método subjetivo utilizado por Carey e Irick (1960) consiste na atribuição de nota por um grupo de avaliadores, resultando em um valor médio do nível de serventia ou Valor de Serventia Atual (VSA). As notas vão de 0 (muito ruim) a 5 (muito bom). A seção considerada também deve ser avaliada como 'aceitável' (sim) ou 'não aceitável' (não), ou, ainda, a opção ‘duvidoso' (indeciso).

Assim, considerando-se a variação desse nível de serventia, ou desempenho do pavimento rodoviário, ao longo da vida útil da rodovia, é possível traçar-se uma curva de variação do PSI (Present Serviceability Index) ou VSA (Valor de Serventia Atual) em função do Tempo ou Tráfego. 
A Figura 22, baseada em Fernandes Jr. et al. (2003), ilustra o conceito do desempenho do pavimento.

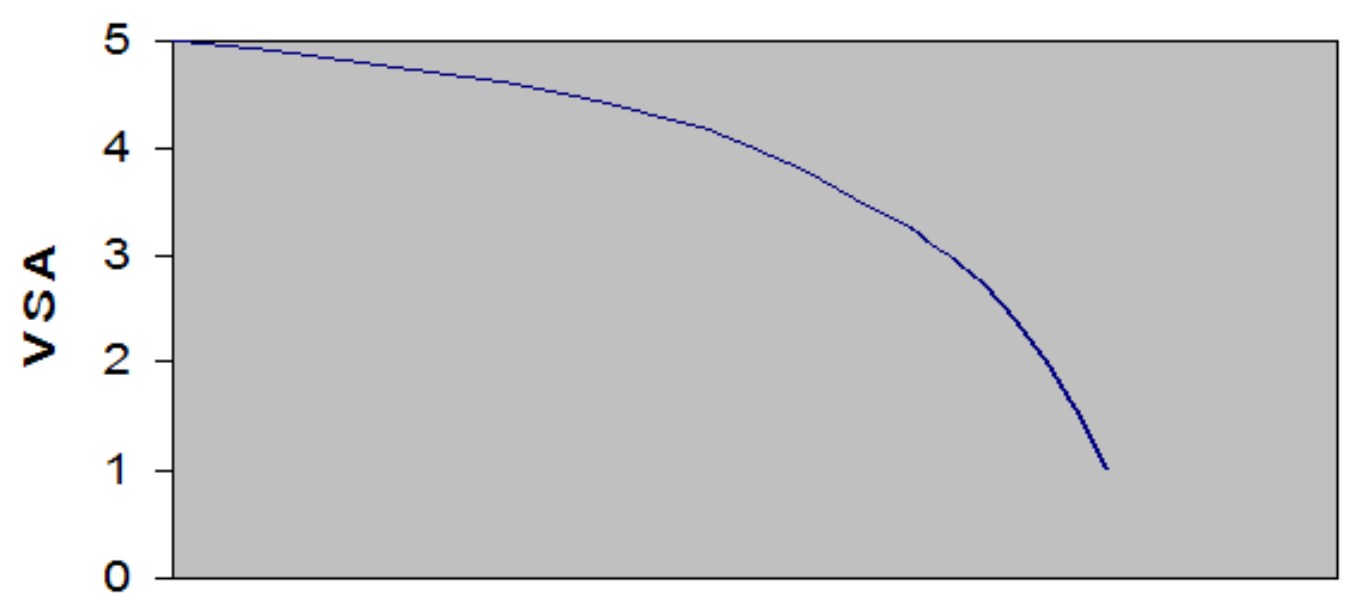

Tempo e / ou Tráfego

Figura 22 - Conceito de Desempenho: Variação do VSA com o Tempo ou Tráfego

Fonte: Fernandes Jr. et al. (2003)

O nível de serventia atribuído à condição atual da via resulta da média das avaliações, sendo que 4 a 5 é o intervalo atribuído a um pavimento novo, enquanto que o intervalo de 1,5 a 2,5 corresponde a um pavimento no limite da necessidade de reparos. A Figura 23, extraída de Fernandes Jr. et al. (2003), ilustra o limite mínimo aceitável para se efetuar os reparos em um pavimento.

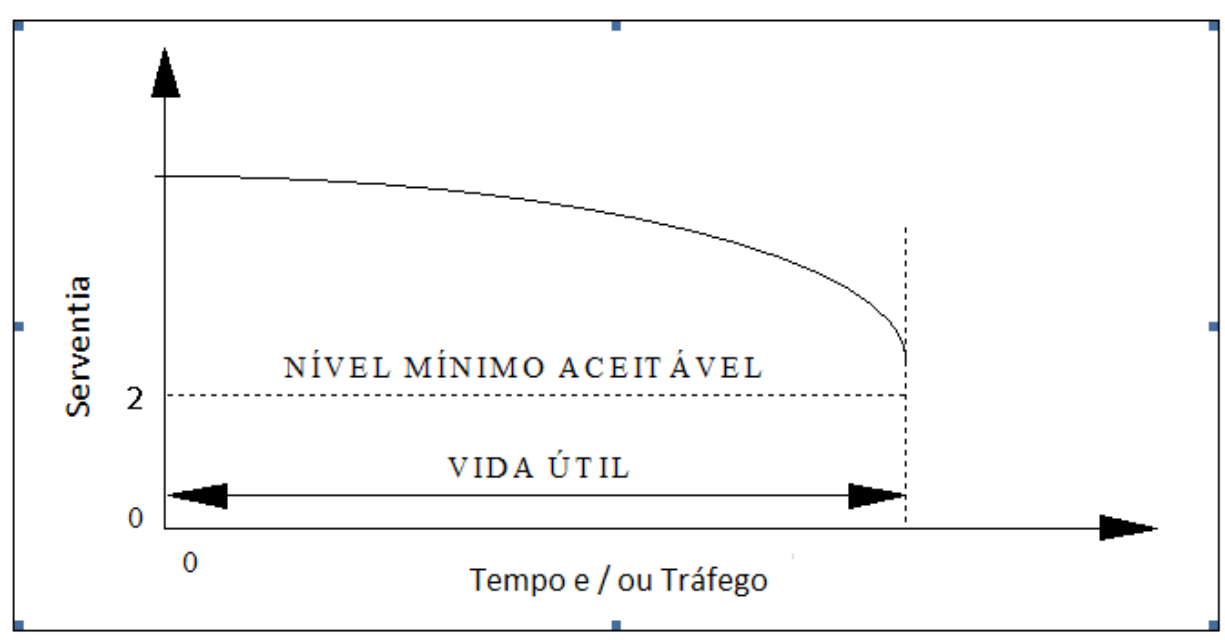

Figura 23 - Necessidade de intervenção com base do conceito de serventiadesempenho

Fonte: Fernandes Jr. et al. (2003) 
São levados em conta vários atributos para 'qualificar' o pavimento, especialmente:

$\checkmark$ o quanto satisfatoriamente veículo e via estão interagindo na velocidade considerada;

$\checkmark$ o quanto a aparência da via está prejudicada em termos de trincas, buracos, textura e cor.

\subsection{2 - Avaliação Objetiva}

Enquanto a avaliação subjetiva expressa a opinião dos avaliadores com relação ao pavimento rodoviário, a avaliação objetiva mensura os defeitos que afetam a serventia do pavimento.

A irregularidade longitudinal do pavimento é a propriedade mais facilmente perceptível aos usuários. Um exemplo de irregularidade pode ser visto na Figura 24, extraída da Norma DNIT 005/2003-TER.

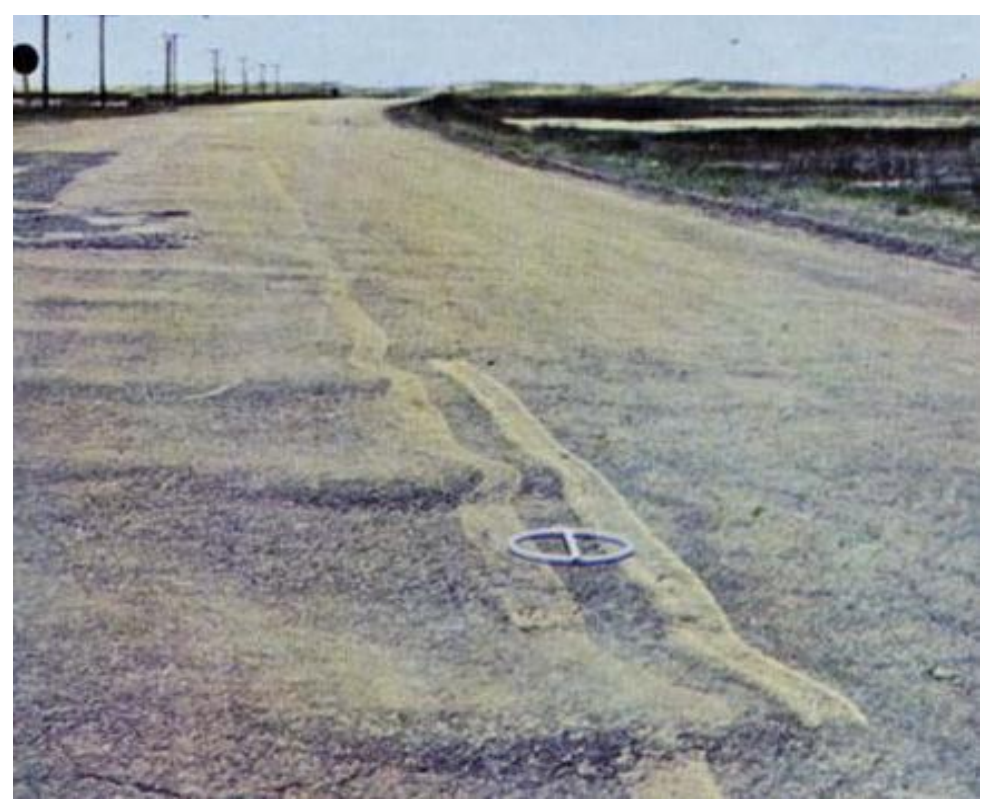

Figura 24 - Irregularidade Longitudinal

Fonte: Norma DNIT 005/2003 - TER (2003)

A irregularidade longitudinal dos pavimentos é definida como sendo distorções na superfície do pavimento em relação a um plano de referência. 
Também pode ser avaliada a capacidade de suporte da via, ou seja, se o pavimento tem capacidade de suportar as cargas a que será submetido durante sua vida útil. Outra forma de avaliação relacionada à segurança viária é a determinação do coeficiente de atrito entre via e veículo, e averiguação de sua adequação ou não.

Existem equipamentos que avaliam a irregularidade longitudinal, a capacidade de suporte e o atrito entre via e veículo.

Para avaliação da irregularidade longitudinal, podem ser utilizados: perfilômetros, perfilógrafos, equipamentos do tipo resposta.

Os perfilômetros medem as variações angulares entre o plano considerado e a superfície rodoviária (Figuras 25 e 26). Os perfilógrafos medem as variações de cota do pavimento entre os vários conjuntos de roda que suportam a estrutura do equipamento (Figura 27). A Figura 25 foi extraída de Fernandes Jr. et al. (2003).

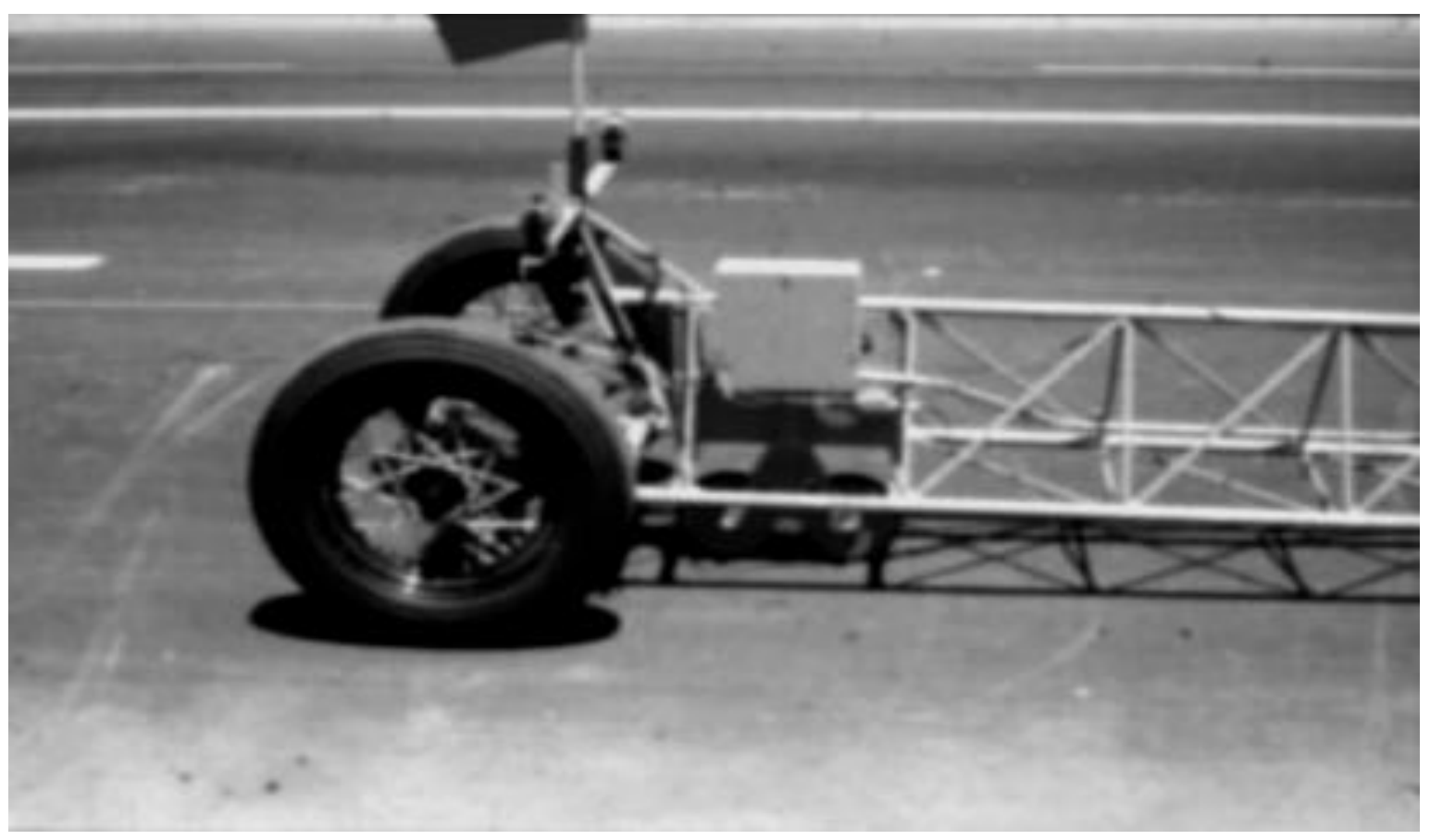

Figura 25 - Perfilômetro CHLOE, utilizado no AASHO Road Test

Fonte: Fernandes Jr. et al. (2003) 


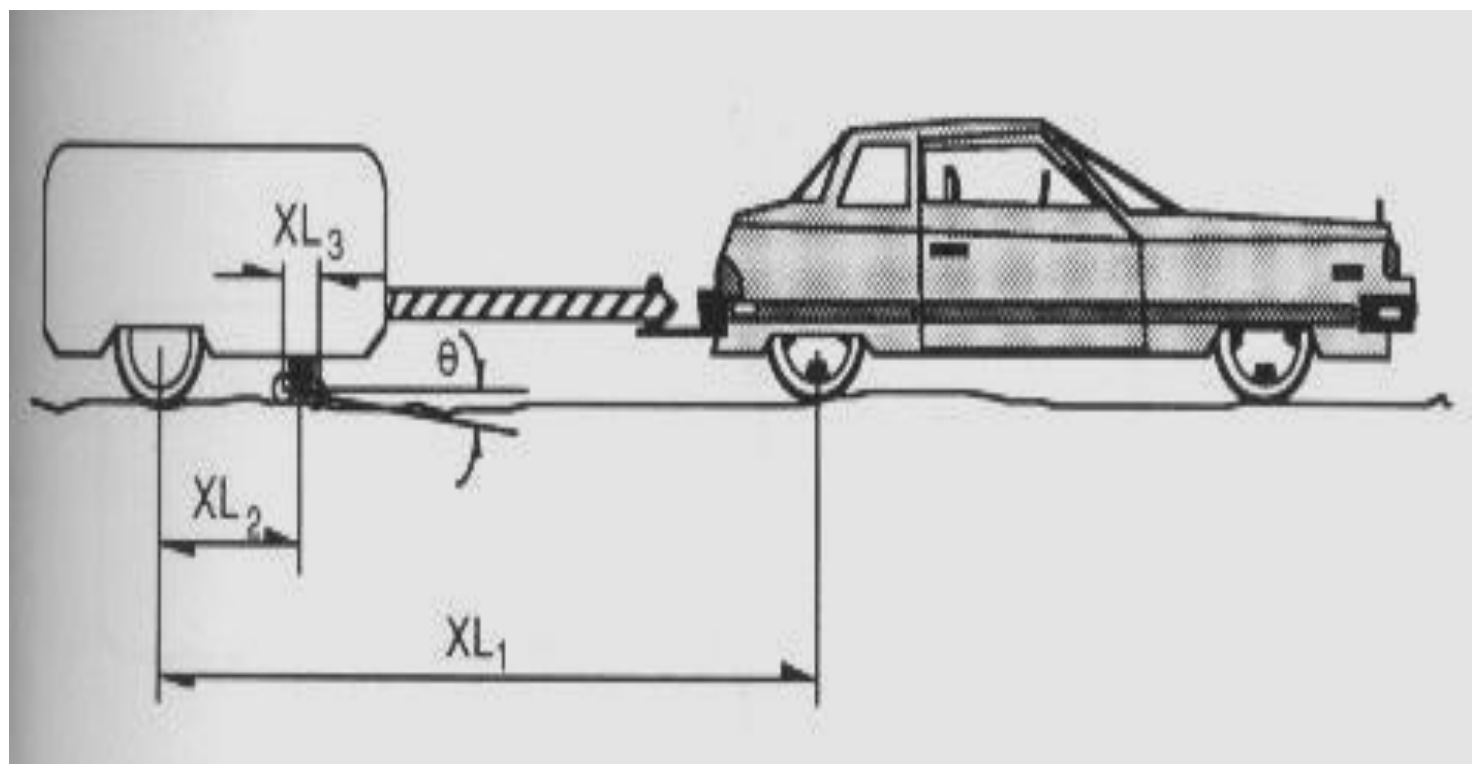

Figura 26 - Esquema do Perfilômetro CHLOE

Fonte: Haas et al. (1994)

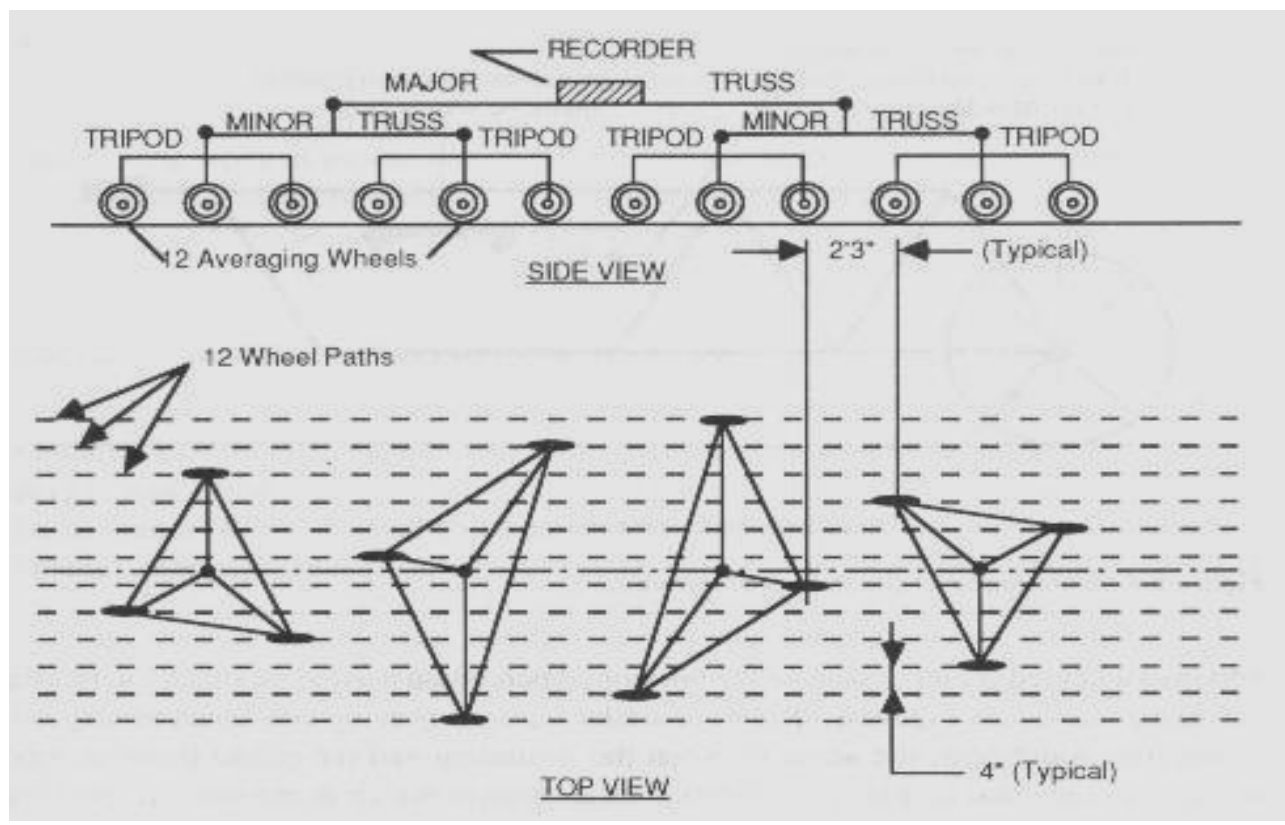

Figura 27 - Esquema de um Perfilógrafo

Fonte: Haas et al. (1994)

Os equipamentos de avaliação do tipo resposta quantificam a irregularidade longitudinal indiretamente, medindo o movimento diferencial entre o eixo da roda e o corpo do veículo utilizado. Essas avaliações dependem, portanto, das características do sistema de suspensão do veículo e da velocidade de deslocamento. A Figura 28 ilustra esse equipamento. 


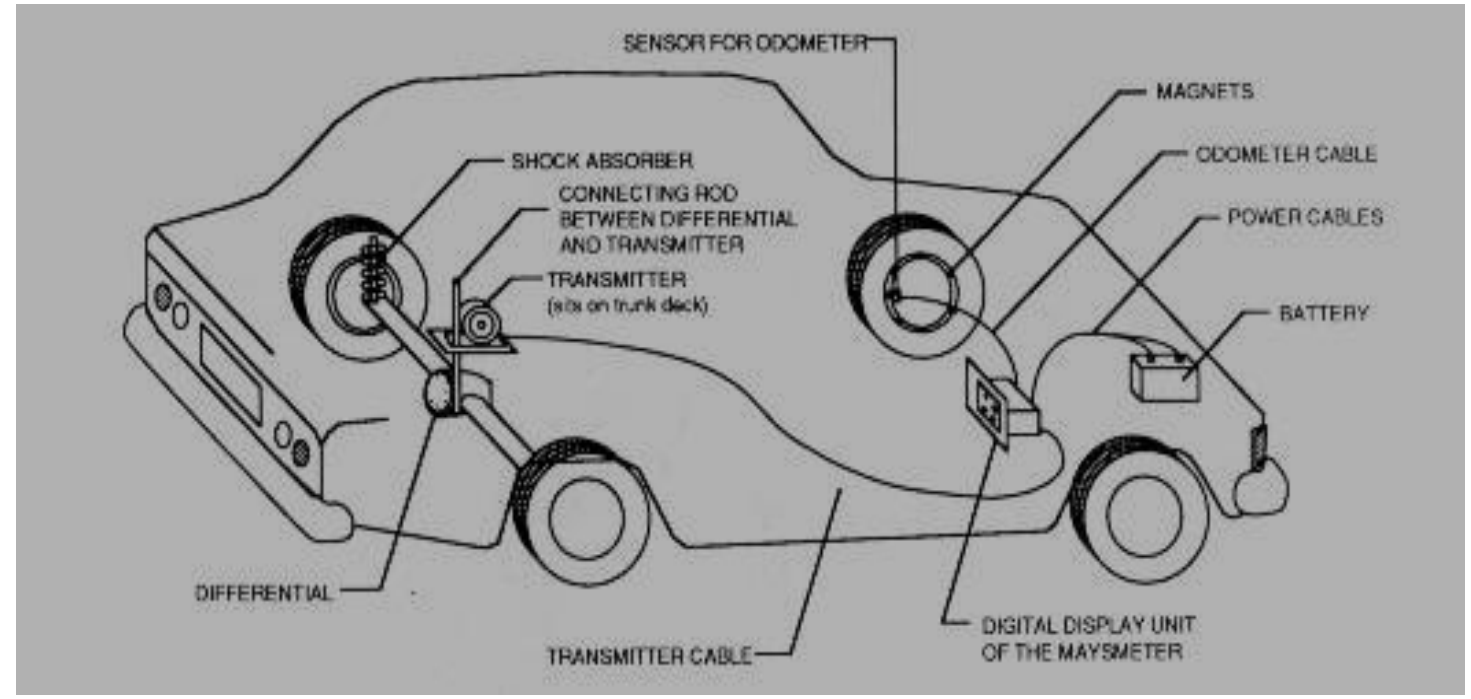

Figura 28 - Maysmeter: medidor de irregularidade do tipo resposta

Fonte: Haas et al. (1994)

Também podem ser utilizados os acelerômetros, que quantificam a aceleração vertical ('solavancos') a que o veículo é submetido durante o trajeto sobre o pavimento em análise. A Figura 29 ilustra um veículo equipado com acelerômetro e foi extraída de Fernandes Jr. et al (2003).

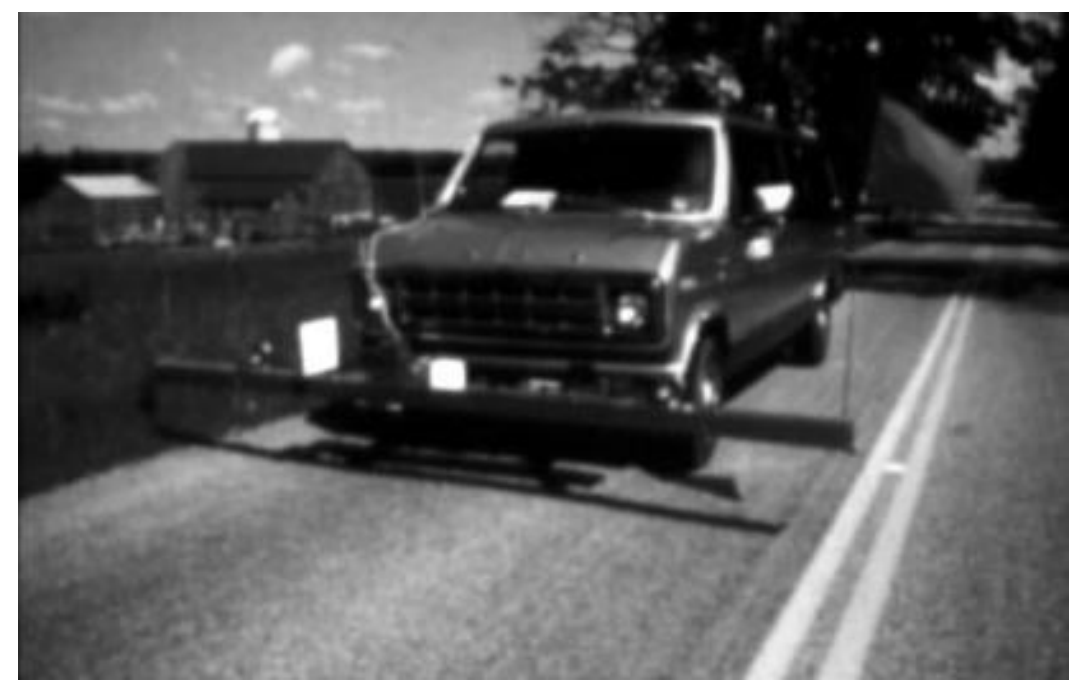

Figura 29 - Car Road Meter: equipado com acelerômetro desenvolvido pelo FHWA Fonte: Fernandes Jr. et al. (2003)

Para se avaliar a capacidade de suporte de um pavimento podem ser efetuados ensaios estruturais, destrutivos ou não destrutivos. 
No primeiro caso, são coletadas amostras do pavimento para ensaios em laboratório. No segundo caso, são feitas medições da deflexão do pavimento, podendo ser utilizados os seguintes dispositivos: viga Benkelman, defletômetros vibratórios, defletômetros de impacto (FWD - Falling Weight Deflectometer). Tanto a viga Benkelman como o FWD podem fornecer a bacia de deflexão da seção avaliada. A bacia de deflexão consiste no traçado dos valores das medidas dos deslocamentos elásticos ou recuperáveis em vários pontos a partir do centro do carregamento (ponto de aplicação de carga). Assim sendo, logo abaixo deste centro considerado, ficam os maiores valores, e, quando se afasta do centro, esses deslocamentos são cada vez menores, até serem desprezíveis. A Figura 30, extraída de Bernucci et al. (2007), ilustra a bacia de deflexão.

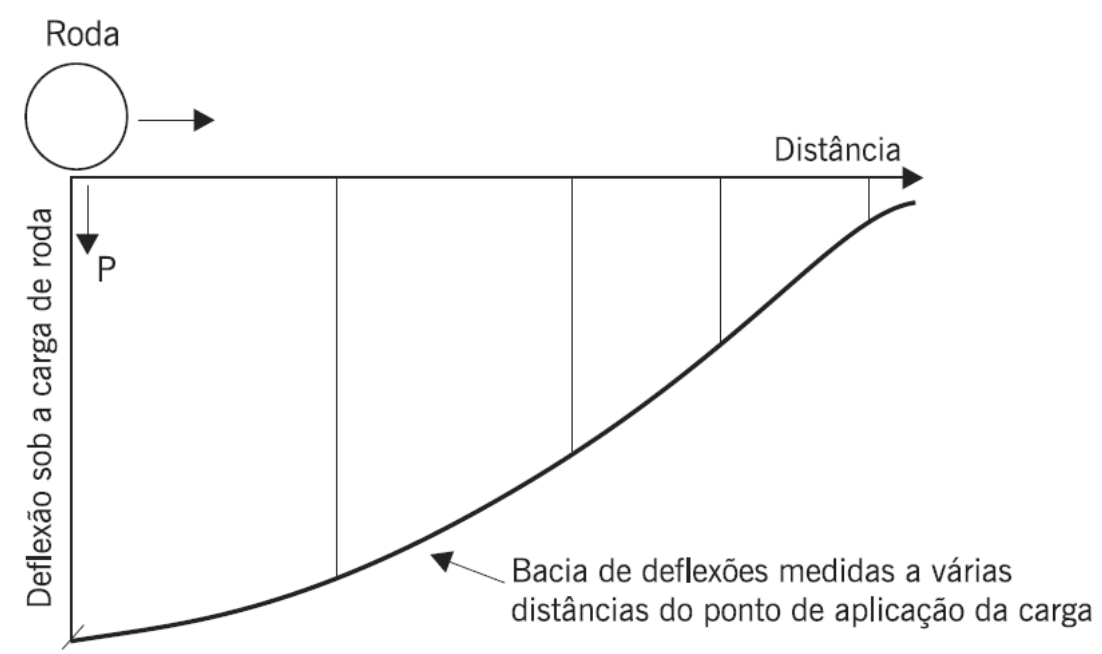

Figura 30 - Esquema de leituras para a obtenção da bacia de deflexão Fonte: Bernucci et al. (2007)

A Viga Benkelman é um equipamento utilizado com bastante frequência, tendo sido inclusive o equipamento utilizado para as avaliações estruturais efetuadas pelo DER no trecho do Estudo de Caso. Esse aparelho possui uma parte fixa e uma parte móvel. A parte fixa é apoiada no pavimento por meio de três pés reguláveis. A parte móvel é acoplada à parte fixa através de uma articulação, uma de suas extremidades fica em contato com o pavimento (ponta de prova) e a outra extremidade fica em contato com o extensômetro que acusa qualquer movimento vertical da ponta de prova. A parte fixa é provida de um vibrador com a função de reduzir o atrito entre todas as peças móveis durante a operação. 
A norma que prescreve o método de ensaio para a determinação das deflexões nos pavimentos pela Viga Benkelman é a DNER-ME 24/94. As Figuras 31 e 32, extraídas da Norma DNER-ME 024/94 (1994), mostram, respectivamente, o esquema da viga Benkelman e o esquema de referência na viga e no caminhão que a transporta.

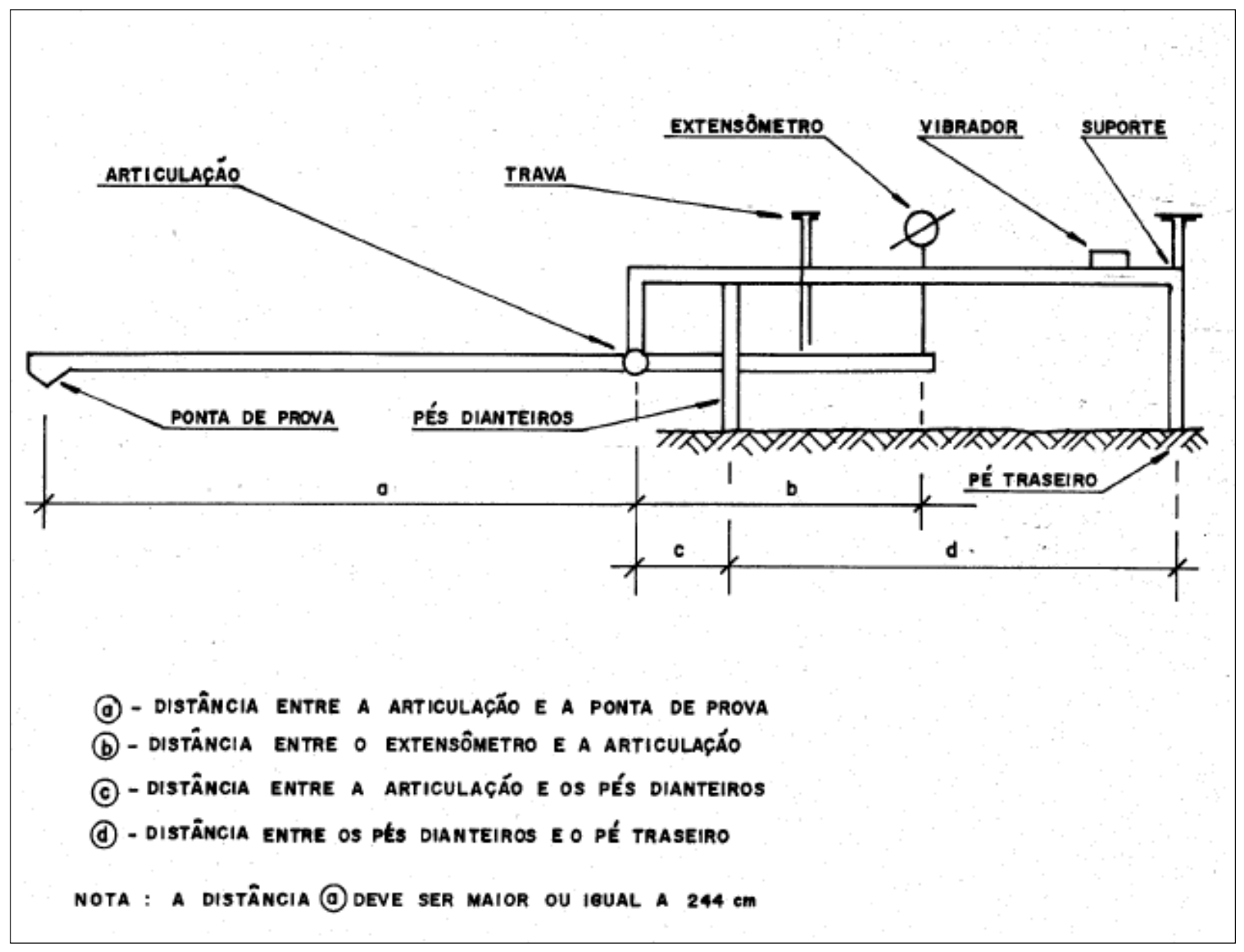

Figura 31 - Esquema da Viga Benkelman

Fonte: Norma DNER-ME 024/94 (1994) 


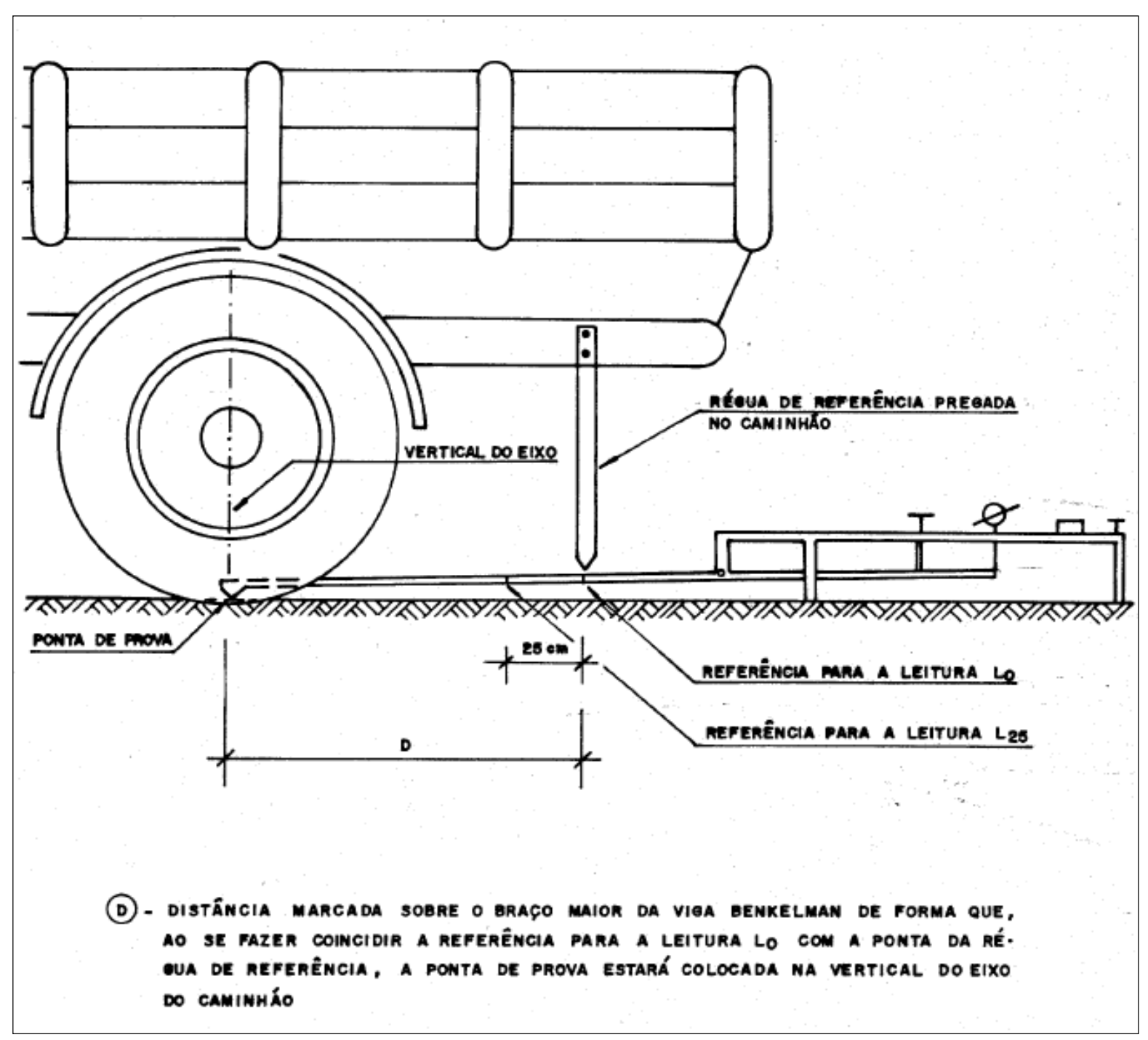

Figura 32 - Esquema de referência na viga e no caminhão Fonte: Norma DNER-ME 024/94 (1994)

Para se avaliar as condições de segurança viária, pode se verificar o atrito superficial pneu-pavimento, que também pode informar se um determinado segmento viário apresenta atrito suficiente para que o tráfego seja seguro neste trecho. Existem equipamentos, tipo Mu-Meter, que medem as forças de atrito em um reboque trafegando com as rodas travadas, a diferentes velocidades, sobre um pavimento molhado. A Figura 33, extraída de Bernucci et al. (2007), mostra um detalhe desse tipo de equipamento. 


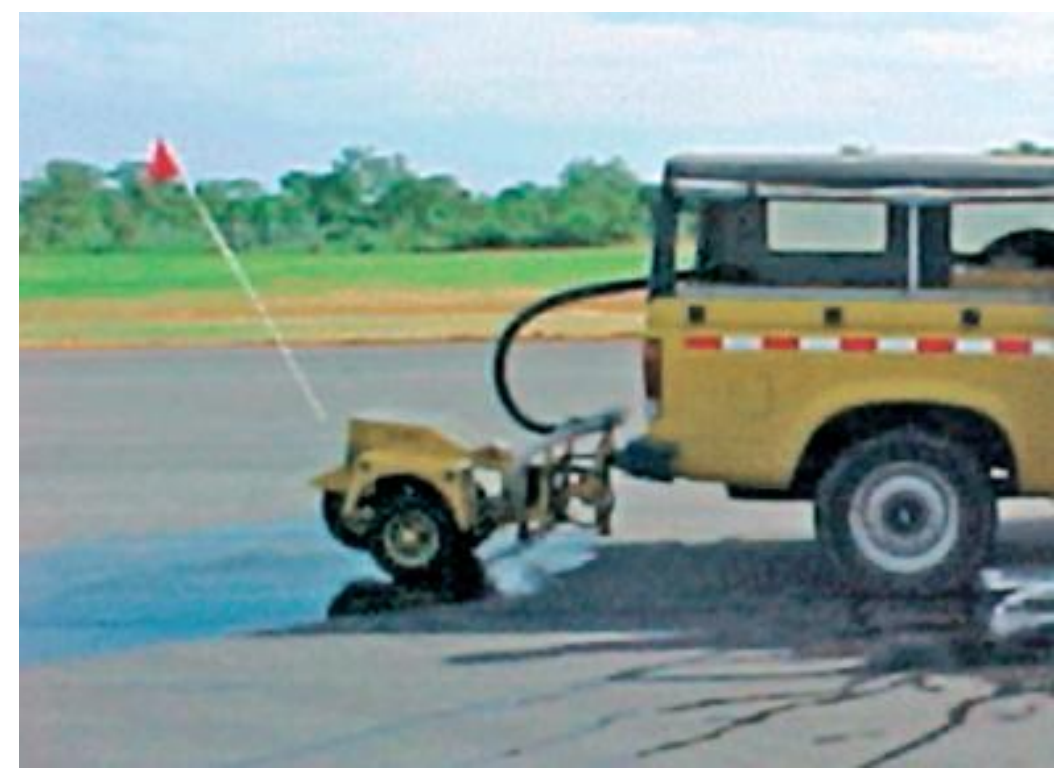

Figura 33 - Exemplo de equipamento de medida de atrito Mu-Meter Fonte: Bernucci et al. (2007)

\subsection{3 - Aspectos das Avaliações nos EUA de relevância ao Brasil}

As avaliações efetuadas nos EUA buscam detalhamento e precisão, sempre com utilização dos equipamentos mais modernos. Esse tipo de procedimento muitas vezes pode encarecer e atrasar a tomada de decisões necessárias. Entretanto, a confiabilidade do SHRP tem demonstrado ser adequada nos casos em que se exige uma precisão maior. Sendo assim, em muitos casos, ao se efetuar a avaliação de defeitos no Brasil, poderiam ser utilizadas algumas orientações das normas dos Estados Unidos, quando for necessária uma margem de segurança maior.

\subsection{Avaliações de Pavimentos Flexíveis na França}

Entre os anos de 1965 e 1967, foram feitas avaliações nas rodovias da França, com o intuito de se definir um plano de ação para sanar problemas advindos do rigoroso inverno de 1962/1963 que afetou bastante as vias francesas. Posteriormente, entre 1970 e 1978, foram desenvolvidos estudos de reforços coordenados para recuperar a malha viária. Dentro desse período foi publicado o catálogo das degradações de pavimentos (1972) e o guia de auscultação dos pavimentos flexíveis (1977). 
Na sequência das novas publicações, chegou-se à preocupação com a implantação de sistemas de apoio à gestão da conservação rodoviária, dentro da qual o método de avaliações, VIZIR, veio atender esse novo objetivo.

A abordagem efetuada pelas normas francesas é diferenciada, especialmente pelo fato de serem definidos dois tipos de degradações: as do tipo A, que estão ligadas à capacidade de suporte ou estrutural do pavimento rodoviário, e as do tipo B, que estão ligadas a outras causas que não esta (defeito de construção ou na qualidade de um produto, condição local particular que o tráfego pode acentuar, outras).

Como os 'manuais franceses' adotam esse tipo de classificação, é necessário que fique bem clara a origem do defeito tratado. Sabendo se existe ou não problema estrutural, é possível definir melhor o tipo mais adequado de intervenção a cada caso.

No caso das degradações do tipo $\mathrm{B}$, a opção pelo tipo de intervenção (solução para o problema) deriva do reconhecimento da degradação somente, não sendo necessário recorrer a outros parâmetros para fazer o diagnóstico. No caso das degradações do tipo A, a solução vai depender de muitos fatores e o diagnóstico associará degradação, suporte, tráfego. Assim considerando, as degradações do tipo B só são analisadas quando houver ausência das degradações do tipo A.

Além disso, é necessária a definição de dois parâmetros:

$\checkmark$ extensão (comprimento, área, quantidade de ocorrência);

$\checkmark$ gravidade (baixa, média, alta).

\subsection{1 - Índice de degradação de Superfície (IS)}

O índice de degradação, também chamado índice visual global, é calculado sobre uma extensão de rodovia, a partir de três grupos de degradação: fissuração (que origina o defeito estrutural 'trincas por fadiga'), deformações (ou trilha de roda) e remendos. 
A Figura 34, extraída de Bernucci et al. (2007), ilustra uma ocorrência de trinca por fadiga com erosão (início de buraco ou panela).

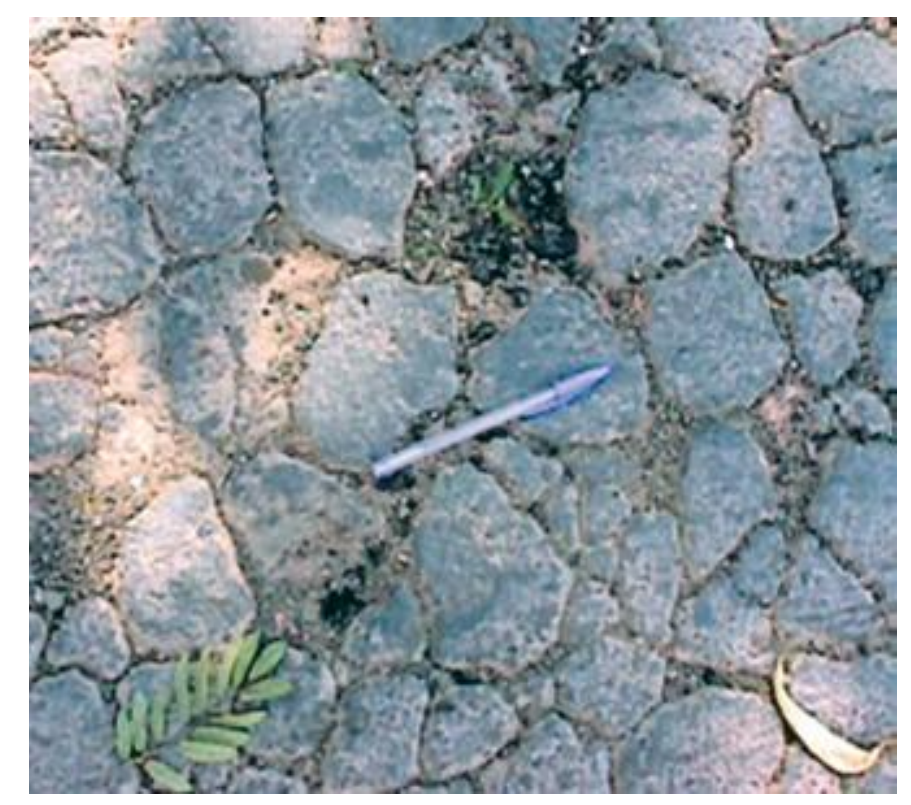

Figura 34 - Trincas por Fadiga com erosão

Fonte: Bernucci et al. (2007)

Segundo o VIZIR, calcula-se o IF, ou 'índice de fissuração', que é definido pela gravidade e extensão de fissuração ou trincas por fadiga. Em seguida calcula-se o ID, ou 'índice de deformação', que é definido pela gravidade e extensão de deformação permanente. E, finalmente, combinam-se os dois índices e corrige-se pela 'taxa de reparação', que é determinada pela gravidade e pela extensão de remendos.

Através desse procedimento, obtem-se o IS, que é o 'índice de degradação da superfície', ou também o 'estado visual'. Esse índice varia de 1 a 7 . As notas 1 e 2 correspondem a bons estados. As notas 3 e 4 correspondem a estados médios. As notas 5 , 6 e 7 correspondem a um péssimo estado, necessitando grandes trabalhos de conservação ou de reforço.

Note-se que essa classificação de índices entre 1 e 7 acaba sendo desnecessária, tendose em vista que depois os estados visuais são agrupados em apenas três: bom (1 e 2), médio (3 e 4) e ruim (5 a 7). 


\subsection{2 - Capacidade de suporte}

Através de medidas das 'deflexões' no pavimento, é feita a avaliação da 'capacidade de suporte' do pavimento. São medidas deflexões nos trechos analisados, sendo que são classificadas três categorias: até d1 o pavimento se comporta bem, além de d2 o pavimento se comporta mal, entre esses limites está a região intermediária.

Para serem fixados esses limites são levados vários fatores em consideração, tais como, ambiente climatológico, natureza e espessura dos pavimentos, solos, cargas de eixo. Também é conveniente levar-se em consideração o volume de tráfego no local para se determinar os limites d1 e d2, sendo que quanto maior for o tráfego menor será a deflexão admissível.

\subsection{3 - Aspectos de Avaliações na França de relevância ao Brasil}

A Avaliação do Índice de Degradação da Superfície (Estado Visual) e da Capacidade de Suporte fornecem subsídios para 'tomadas de decisões', principalmente 'em nível de rede', ou seja, 'em nível macro'. Essas análises pretendem abranger aspectos objetivos e subjetivos de maneira complementar.

Para uma tomada final de decisão e definições de 'soluções específicas para os vários trechos analisados' (decisão 'em nível de projeto'), também deve ser levado em consideração o VDM (volume de tráfego diário médio) da rodovia. Para maiores VDMs a tolerância para intervenção é menor e a avaliação deverá ocorrer a intervalos de tempo menores.

Segundo Prestes (2001) o tempo de aplicação dos métodos utilizando o SHRP foram mais demorados que o VIZIR, o que pode ser explicado tanto pelo maior número de defeitos avaliados como pelo fato das medições das áreas dos defeitos despenderem mais tempo. Entretanto, a confiabilidade do SHRP tem se demonstrado maior, apresentando resultados mais detalhados e precisos. 


\subsection{Avaliações de Pavimentos Flexíveis no Brasil}

As avaliações de pavimento utilizadas no Brasil e detalhadas em normas específicas, norteiam-se pelas normas norte-americanas com apenas algumas orientações específicas para o caso brasileiro.

A DNIT 005/2003-TER, revisão da DNER-TER 001/78, define os defeitos a serem avaliados. A partir da DNIT 005/2003-TER, foram elaboradas as outras normas de procedimentos. Para a Avaliação Subjetiva é utilizada a DNIT 009/2003-PRO, revisão da DNER-PRO 007/94. Para a Avaliação Objetiva é utilizada a DNIT 006/2003-PRO, revisão da DNER-PRO 008/94, e a DNIT 007/2003-PRO, revisão da DNER-ES 128/83. Para a avaliação da superfície dos pavimentos através do Levantamento Visual Contínuo é utilizada a DNIT 008/2003-PRO.

\subsection{1 - Avaliação Subjetiva}

A Norma DNIT 009/2003-PRO normatiza alguns procedimentos para que possa ser feita uma avaliação subjetiva com embasamento adequado. É utilizada em nível federal, estadual e municipal, quando for o caso.

O VSA ou Valor de Serventia Atual é determinado através de avaliações subjetivas efetuadas por um grupo de avaliadores que percorrem o trecho sob análise, registrando suas opiniões sobre a capacidade do pavimento atender às exigências do tráfego que sobre ele atua, no momento da avaliação, quanto à suavidade e ao conforto. Esse levantamento deve obedecer a algumas diretrizes: 
$\checkmark$ as pessoas (avaliadores) devem ter sensibilidade para o trabalho a ser executado;

$\checkmark$ os trechos devem ter extensão fixa, aspecto uniforme e, de preferência, devem ser pequenos para avaliação em espaço de tempo reduzido;

$\checkmark$ deverá ser utilizada uma ficha padrão;

$\checkmark$ o trecho deve ser avaliado como se fosse uma rodovia de tráfego intenso e para veículos comerciais ou de passageiros;

$\checkmark$ o aspecto a ser considerado é somente o atual, mesmo que haja possibilidade aparente de ruptura no futuro;

$\checkmark$ a avaliação deve ser feita em condições climáticas favoráveis;

$\checkmark$ não devem ser levados em conta os aspectos geométricos da rodovia, nem os cruzamentos ferroviários, acessos a pontes, recalques de bueiros, outros;

$\checkmark$ devem ser considerados principalmente buracos, saliências, irregularidades transversais e longitudinais da superfície.

O VSA é resultado da somatória das notas atribuídas pelos avaliadores dividida pelo número de avaliadores. Esse valor avaliado é sempre para o momento específico analisado.

As notas são relacionadas aos conceitos abaixo:

$$
\begin{array}{ll}
\checkmark & \text { Péssimo (entre 0 e 1) } \\
\checkmark & \text { Ruim (entre 1 e 2) } \\
\checkmark & \text { Regular (entre 2 e 3) } \\
\checkmark & \text { Bom (entre } 3 \text { e 4) } \\
\checkmark & \text { Ótimo (entre 4 e 5) }
\end{array}
$$

Essas notas embasarão as tomadas de decisões necessárias, sendo conveniente se considerar conjuntamente a 'avaliação objetiva'. 
Deve-se destacar que Carey e Irick (1960) evitaram usar os termos 'péssimo', 'sofrível', 'ótimo', 'excelente', etc. Foi dada preferência à utilização de termos simples e diretos como 'muito bom' ou 'muito ruim'. Essa opção permite se pensar em 'intervalos' porque as notas abrangem mais de um valor (0-1 e 4-5) e não valores absolutos. A opção da norma brasileira em adotar os termos 'péssimo' e 'ótimo' pode dar margem a interpretações diferenciadas.

\subsection{2 - Avaliação Objetiva}

A Norma DNIT 006/2003-PRO, posteriormente acrescida da Norma DNIT 007/2003PRO, normatiza alguns procedimentos para que se possa determinar as ocorrências aparentes e as deformações permanentes nas trilhas de roda.

As ocorrências a serem registradas encontram-se definidas nas tabelas das normas citadas. Em linhas gerais são avaliadas: trincas, afundamento (plástico ou de consolidação), ondulação ou corrugação, escorregamento, exsudação, desgaste, panelas ou buracos. As trincas podem ser isoladas (transversais ou longitudinais) ou interligadas (em bloco ou com aparência de couro de jacaré). Esses defeitos foram detalhados no capítulo 2 .

São demarcadas estações a serem inventariadas (ou locais de análise). A extensão a ser analisada, em cada estação inventariada, é de 3,00 m antes e 3,00 m depois. Essas estações são marcadas a cada $20 \mathrm{~m}$ alternados em relação ao eixo da pista de rolamento ( $40 \mathrm{~m}$ em $40 \mathrm{~m}$ em cada faixa de tráfego). As superfícies a serem avaliadas devem ser delimitadas por meio de pintura com tinta de demarcação (as espessuras dos traços são detalhadas em norma) e numeradas com clareza para evitar dúvidas no momento do levantamento.

O objetivo é determinar a flecha na trilha de roda, através de uma treliça de alumínio padronizada. Conjuntamente são identificados, delimitados e registrados todos os outros defeitos. 
Todas as recomendações de norma deverão ser rigorosamente obedecidas com a finalidade de se garantir um padrão de procedimento. Ao final do trabalho são identificados dois parâmetros:

$\checkmark$ fr, que é a frequência relativa (obtida através da fórmula fa $\times \mathbf{1 0 0} / \mathbf{n}$, onde fa é o número de vezes em que a ocorrência foi verificada e $\mathbf{n}$ é o número de estações inventariadas ou locais de análise)

$\checkmark$ fp, que é o fator de ponderação (tabelado em norma, variando de acordo com o defeito avaliado)

É importante salientar que os fatores de ponderação referente às trincas interligadas mais graves, aos afundamentos, às panelas ou buracos, aos remendos, às ondulações ou corrugações e ao escorregamento apresentam valores maiores. Com exceção das trincas em blocos (também consideradas no item 'trincas interligadas'), das ondulações e do escorregamento, os outros itens são os defeitos considerados, nas normas francesas, como defeitos de origem estrutural. No caso destas normas, são os valores de maior peso no momento da avaliação do pavimento. Os valores dos fatores de ponderação, extraídos da Norma DNIT 006/2003-PRO, estão no Anexo 2, na página 108.

Com a relação $\mathbf{f r} \times \mathbf{f p}$, obtem-se o IGI (índice de gravidade individual) para cada defeito e o IGG (índice de gravidade global) que é a soma dos IGIs parciais. Esses valores são associados aos conceitos abaixo:

$$
\begin{array}{ll}
\checkmark & \text { Péssimo }(\mathrm{IGG}>160) \\
\checkmark & \text { Ruim }(80<\mathrm{IGG}<160) \\
\checkmark & \text { Regular }(40<\mathrm{IGG}<80) \\
\checkmark & \text { Bom }(20<\mathrm{IGG}<40) \\
\checkmark & \text { Ótimo }(0<\mathrm{IGG}<20)
\end{array}
$$

Tendo em vista os valores anteriores, as tomadas de decisões poderão ser mais bem embasadas. Vale lembrar, novamente, a questão dos termos 'péssimo' e 'ótimo', já mencionada no item 3.4.1. 


\subsection{3 - Levantamento Visual Contínuo}

A Norma DNIT 008/2003-PRO fixa as condições de avaliação do pavimento pelo processo de Levantamento Visual Contínuo, determinando-se o ICPF (Índice de Condição de Pavimentos Flexíveis) e proporcionando elementos para o cálculo do IGGE (Índice de Gravidade Global Expedito). A partir desses índices, encontra-se o IES (Índice do Estado de Superfície do Pavimento) para cada trecho considerado.

Para cálculo do ICPF são levados em conta todos os defeitos detectados durante o processo de LVC. Para o cálculo do IGGE são levados em conta os defeitos 'trincas', 'deformações permanentes', 'panelas' e 'remendos'. Para efeito do LVC, são adotadas as definições e nomenclaturas da Norma DNIT 005/2003-TER, que constam no Anexo 1 (página 107) deste trabalho.

No levantamento visual contínuo deve ser usado um veículo equipado com velocímetro/odômetro calibrado para aferição da velocidade de operação e das distâncias percorridas. Devem ser evitados os dias chuvosos, com neblina ou com pouca luz natural (início ou final de dia). Além do motorista, deve haver dois técnicos, no mínimo, para esse levantamento. A velocidade média de trabalho é de $40 \mathrm{~km} / \mathrm{h}$. Os trechos a serem avaliados devem ser divididos de maneira a preservarem alguma homogeneidade. Para se efetuar o levantamento é preenchido um formulário constante na referida norma.

Todas as instruções detalhadas para o cálculo do ICPF, recomendadas na Norma DNIT 008/2003-PRO, deverão ser rigorosamente obedecidas, com a finalidade de se garantir um padrão homogêneo de procedimento.

No caso do IGGE, são levados em conta apenas alguns defeitos, e a fórmula para o cálculo é: 
IGGE $=($ Pt $\times$ Ft $)+($ Poap $\times$ Foap $)+($ Ppr $\times$ Fpr $)$, onde $:$

$\checkmark \mathrm{Pt}$ e Ft $=$ peso e frequência do conjunto de trincas;

$\checkmark$ Poap e Foap $=$ peso e frequência do conjunto de deformações;

$\checkmark$ Ppr e Fpr $=$ peso e frequência do conjunto de panelas e remendos.

Aos defeitos trincas, deformações e panelas ou remendos são atribuídos pesos de acordo com sua gravidade. Os pesos menores são para as trincas e os pesos maiores são para as panelas e remendos. É importante observar que alguns dos defeitos utilizados para o cálculo do IGGE são os que as normas francesas indicam como sendo defeitos de origem estrutural (trincas, no caso estão inseridas as trincas por fadiga, deformações, remendos). Após o cálculo do ICPF e do IGGE será determinado o IES, de acordo com Tabela 3 (DNIT 008/2003-PRO):

Tabela 3 - Variação dos Valores do IGGE.

\begin{tabular}{|c||c|c|c|}
\hline Descrição & IES & Código & Conceito \\
\hline IGGE $<20$ e ICPF $>\mathbf{3 , 5}$ & 0 & A & Ótimo \\
\hline IGGE $<20$ e ICPF $<3,5$ & 1 & B & Bom \\
\hline $\mathbf{2 0}<$ IGGE $<40$ e ICPF $>\mathbf{3 , 5}$ & 2 & B & Bom \\
\hline $\mathbf{2 0}<$ IGGE $<40$ e ICPF $<3,5$ & 3 & C & Regular \\
\hline 40<IGGE $<60$ e ICPF $>\mathbf{2 , 5}$ & 4 & C & Regular \\
\hline $\mathbf{4 0}$ IGGGE $<60$ e ICPF $<2,5$ & 5 & D & Ruim \\
\hline 60<IGGE $<90$ e ICPF $>\mathbf{2 , 5}$ & 7 & D & Ruim \\
\hline 60<IGGE $<90$ e ICPF $<2,5$ & 8 & E & Péssimo \\
\hline IGGE $>90$ & 10 & E & Péssimo \\
\hline
\end{tabular}

\subsection{4 - Considerações sobre as Avaliações efetuadas no Brasil}

Como é possível se observar, as avaliações baseadas nas normas do DNIT abrangem três possibilidades: avaliação subjetiva (3.4.1), avaliação objetiva (3.4.2), avaliação com ambas as abordagens (3.4.3). 
Esse último caso trata-se do LVC (Norma DNIT 008/2003-PRO) que alia o IGGE (análise objetiva) com o ICPF (análise um pouco mais subjetiva).

Em alguns locais é conveniente, além das avaliações objetivas e subjetivas, efetuar-se uma pesquisa com relação ao entendimento dos motoristas em geral sobre as condições do pavimento. Um trabalho como esse foi desenvolvido por Danieleski (2004), no sistema viário de Porto Alegre, sendo constatada a utilidade da aplicação das avaliações conjuntas.

\subsection{Avaliação Objetiva com Determinação do Índice de Condição do Pavimento (ICP)}

Após a identificação dos defeitos, é necessário definir que combinações de extensão e severidade dos diferentes defeitos indicam que uma seção de pavimento apresenta-se em pior condição que outra. Com esse intuito, são desenvolvidos os índices de defeitos combinados. Recomenda-se a utilização do Índice de Condição do Pavimento (ICP) desenvolvido, na década de 1970, pelo Corpo de Engenheiros do Exército dos Estados Unidos (USACE - United States Army Corps of Engineers) com o intuito de quantificar a condição de pavimentos de estradas, ruas, aeroportos e áreas de estacionamento (SHAHIN, 1994).

Um Índice de Condição do Pavimento (ICP) é um índice numérico que varia de 0 (para pavimentos em condições de rolamento muito ruins) a 100 (para pavimentos em condições de rolamento muito boas), podendo ser avaliado subjetivamente (por painéis de avaliadores) ou calculado a partir de informações detalhadas de um levantamento de defeitos em campo. Representa o somatório dos efeitos combinados da severidade e extensão de cada defeito que ocorre no trecho em análise, podendo ser representado pela Equação a seguir: 


$$
I C P=100-\left[\left(\sum_{i} E_{i, A} \times F_{i, A}\right)+\left(\sum_{i} E_{i, M} \times F_{i, M}\right)+\left(\sum_{i} E_{i, B} \times F_{i, B}\right)\right]
$$

onde:

$\checkmark \quad \mathrm{E}_{\mathrm{i}, \mathrm{A}}=$ extensão do Defeito i, com Severidade Alta;

$\checkmark \quad \mathrm{F}_{\mathrm{i}, \mathrm{A}}=$ Fator de Ponderação para o Defeito i, com Severidade Alta.

Analogamente:

$\checkmark$ i,M $=$ Defeito i, Severidade Média;

$\checkmark$ i,B $=$ Defeito i, Severidade Baixa.

Geralmente, nem todos os defeitos ocorrem simultaneamente, assim como nem todas as severidades, para um dado defeito, ocorrem num determinado segmento em uma dada avaliação. Com base na importância relativa de cada defeito são definidos os Fatores de Ponderação para os níveis de severidade alta, média e baixa.

Os Fatores de Ponderação diferenciam a influência dos vários tipos de defeitos na perda da serventia do pavimento, pois alguns defeitos têm maior impacto do que outros. Devem, no entanto, ser ajustados para os diversos níveis de severidade e para as condições operacionais e ambientais do local em análise.

Alternativamente, pode-se calcular o ICP a partir de pontos dedutíveis, que vão diminuindo a nota máxima 100 e que são estabelecidos para cada defeito em função do que o avaliador considera em termos de comprometimento da condição do pavimento com base na extensão e na severidade com que o defeito se apresenta. $\mathrm{O}$ valor máximo de dedução, para cada defeito, é estabelecido em função da importância relativa do defeito.

Os valores dos índices combinados podem dar uma indicação sobre que estratégia de manutenção e reabilitação deverá ser adotada. A classificação do pavimento pode utilizar os seguintes parâmetros: 
$\checkmark$ Muito ruim (0 a 30)

$\checkmark$ Ruim (30 a 50)

$\checkmark$ Regular (50 a 70)

$\checkmark \operatorname{Bom}(70$ a 90$)$

$\checkmark$ Muito bom (90 a 100)

Assim sendo, a tomada de decisão pode utilizar os correspondentes parâmetros:

$\checkmark$ Reconstrução (0 a 30)

$\checkmark$ Recapeamento em alguns casos de maneira diferenciada (30 a 80)

$\checkmark$ Manutenção adequada a cada caso (80 a 100)

\subsection{Necessidade das Avaliações para Gerência de Pavimentos em Nível de Rede}

A situação visual do pavimento e a evolução da sua irregularidade longitudinal devem ser acompanhadas durante a vida útil do mesmo. Isso se faz necessário para que possam ser tomadas decisões amplas a longo, médio e curto prazo.

A 'gerência de pavimentos em nível de rede' trabalha com informações resumidas, relacionadas a toda a malha viária, utilizadas para a tomada de decisões administrativas. Algumas características deste sistema são:

$\checkmark$ identificar projetos candidatos a intervenções;

$\checkmark$ priorizar projetos de acordo com seu desempenho, tráfego, custo aos usuários, outros;

$\checkmark$ gerar necessidades de orçamento a curto, médio e longo prazo;

$\checkmark$ analisar estratégias de intervenção, tendo em vista condição atual e previsão da condição futura.

As ações a serem consideradas são: manutenção corretiva, manutenção preventiva, ação postergada, reforço, reconstrução. 
Analisando as várias maneiras de se classificar e avaliar os pavimentos, surge o entendimento de que a maneira de abordagem do problema pelos órgãos técnicos franceses apresenta vantagem sobre a maneira de abordagem norte-americana ou brasileira.

$\mathrm{Na}$ França, são feitas avaliações que permitem determinar o problema de maneira mais ampla, definindo se o pavimento analisado apresenta problemas estruturais ou não, o que permite 'tomar as decisões' de maneira mais ágil e simples. Essas decisões também são embasadas nas medições das deflexões ou irregularidades do pavimento. No trabalho de Prestes (2001) é descrita a experiência com avaliação visual da situação de um trecho pavimentado, concluindo-se pela maior agilidade obtida com a aplicação do método francês.

Para considerações em nível de projeto, aí sim são levadas em considerações outras informações como: importância da rodovia, disponibilidade financeira, casos especiais.

\subsection{Necessidade das Avaliações para Gerência de Pavimentos em Nível de Projeto}

Ao se pensar em 'gerência de pavimentos em nível de projeto', são necessárias algumas considerações. É imprescindível que sejam feitas medições precisas, quando no momento da avaliação das condições do pavimento, assim um padrão de procedimentos se faz obrigatório.

Também são essenciais: fiscalização constante no momento da construção, adequada estimativa do período de vida útil do pavimento e conhecimento das várias opções de reabilitação da via. Só assim poderão ser tomadas as decisões adequadas para cada trecho rodoviário e projetadas as melhores soluções. 
Analisando-se as várias maneiras de se classificar e avaliar os pavimentos, chega-se à conclusão que a maneira de abordagem do problema pelos órgãos técnicos norteamericanos apresenta vantagem sobre a maneira de abordagem francesa. A maneira de abordar esse assunto pelos órgãos técnicos brasileiros é semelhante à norte-americana, mas apresenta algumas incoerências e alguns detalhamentos desnecessários.

Nos EUA, as definições de cada defeito são precisas, a maneira de quantificá-los é clara, e, além disso, as avaliações de sua extensão e gravidade podem ser efetuadas de várias formas. Isso permite que sejam efetuadas medições mais precisas.

No Brasil, existem métodos de avaliação subjetivos, objetivos e unindo os dois critérios, descritos em norma de maneira simples e clara. Existem, entretanto, algumas incoerências e detalhamentos desnecessários dentro da 'classificação' dos defeitos, que foram mencionados no capítulo 2 deste trabalho. Há que se fazer uma ressalva que alguns defeitos são descritos pelo DNIT (Departamento Nacional de Infraestrutura de Transportes) de forma mais clara e objetiva.

Segundo Fernandes Jr. et al. (2003), as várias revisões do trabalho desenvolvido dentro do SHRP fazem dele um método de avaliação bastante confiável. No trabalho de Prestes (2001) também se chegou à conclusão de que embora mais demorado o método utilizado pelo SHRP apresenta maior confiabilidade, obtendo resultados mais detalhados e precisos.

\subsection{Tratamento dado em Áreas Urbanas}

Neste caso existem considerações diferenciadas, pois a ocupação dessas áreas apresenta características distintas das vias rurais, normalmente tratadas nos programas de recuperação e ou reabilitação de pavimentos. 
$\mathrm{Na}$ área urbana o trânsito tem predomínio de veículos leves, na maioria das vias, e a velocidade é inferior às velocidades na área rural. Ocorre uma interferência ampla das ocupações que margeiam as vias e, em alguns casos, das construções subterrâneas, tais como adutoras de água, emissários de esgoto. Essa realidade muitas vezes impossibilita a implementação do que foi projetado na íntegra (NAKAHARA, 2005).

Neste ponto cabe ressaltar que alguns defeitos que ocorrem em rodovias não apresentam grande incidência no meio urbano, tais como Trincas de Bordo ou Desnível entre Pista e Acostamento, pois as contenções laterais (guias e sarjetas) impedem a ocorrência desses defeitos (DANIELESKI, 2004). Outra observação importante é com relação aos Remendos que podem ser necessários, normalmente, para reparar algum dano no pavimento. Entretanto, ocorre uma grande frequência de remendos por conta de obras não relacionadas à utilização da faixa de rolamento, como, por exemplo, no caso de obras subterrâneas (DANIELESKI, 2004).

Esses fatores geram dúvidas e provocam uma grande variação no tipo de decisões a serem tomadas quando se definem os procedimentos a serem efetuados no momento da recuperação dos pavimentos. Como consequência, poderá haver perda de tempo e a gerência de pavimentos desenvolvida no local poderá ser afetada.

Para uma avaliação ágil e simples dos problemas enfrentados nas áreas urbanas, o método francês pode ser utilizado com eficiência. Esse método avalia inicialmente se o defeito tem origem estrutural ou não, e, caso haja problema na estrutura do pavimento, é feita uma estimativa do tipo de trabalho a ser desenvolvido com atribuição do valor de IS. De acordo com esse valor, que compreende notas que vão de 1 a 7, é possível decidir se haverá necessidade de conservação ou reforço. Essa avaliação inicial pode ser muito útil para o caso urbano que apresenta uma grande variedade de ocorrências. Já o método dos Estados Unidos demanda um custo maior com emprego de mão de obra específica, sendo que nem sempre este trabalho tão minucioso é necessário. Um trabalho mais 'macro', ou 'em nível de rede' pode ser o mais adequado para essas áreas. 


\subsection{Tratamento dado em Aeroportos}

Para este tipo de análise, a segurança é muito mais importante do que o conforto, tendo em vista que qualquer irregularidade ou perda de aderência poderá provocar acidentes de amplas proporções, provavelmente com vítimas graves e / ou fatais.

Alguns defeitos que ocorrem nos aeroportos não surgem rotineiramente nas rodovias, tais como: o crescimento de vegetações nas fissuras ou trincas, ainda que estas sejam de dimensões minúsculas, e o derramamento de óleo ou outros produtos. Essas ocorrências podem ser muito mais prejudiciais e constantes do que nas vias rurais (MAGGIE COVALT, 2006).

A deformação superficial, a corrugação, o desgaste, as trincas, especialmente, por fadiga e o bombeamento, especialmente nos bordos das pistas, são defeitos que ocorrem com mais frequência e que necessitam de atenção especial (MAGGIE COVALT, 2006). Para tanto é imprescindível haver limitação criteriosa das cargas que o pavimento suporta e um controle rígido da drenagem, e, ainda, o atendimento às normas com rigor quando por ocasião da execução do pavimento.

As avaliações precisam ser rotineiras. São recomendadas inspeções detalhadas anualmente e gerais mensalmente (TEXAS DOT, 2000). Deve ser feito o levantamento visual dos defeitos. Também devem ser avaliados: atrito pavimento-pneu e irregularidade da pista.

De acordo com as pesquisas efetuadas para este trabalho, as avaliações de pavimentos de aeroportos precisam ser minuciosas e precisas, utilizando métodos objetivos, e os investimentos devem ser aplicados antes de qualquer deterioração do concreto asfáltico. 
Conclui-se que qualquer decisão deve passar pelo 'nível de rede' rapidamente e chegar ao 'nível de projeto', sendo este nível detalhado pelas normas do DNIT aperfeiçoadas pelas normas do SHRP.

\subsection{Conclusões sobre Avaliações dos Defeitos que ocorrem nos Pavimentos}

Um sistema de Gerência de Pavimentos funcionará de maneira eficiente, quanto mais eficiente forem as informações com que o mesmo for subsidiado. Assim sendo, a união das avaliações subjetiva e objetiva pode ser muito útil. Também podem ser utilizadas fotos e filmagens dos trechos estudados. Em alguns casos, o levantamento é feito a pé (FERNANDES JR. et al., 2003), como no desenvolvimento do cálculo do IGG. É importante registrar a extensão e o nível de severidade de cada defeito encontrado.

De acordo com as bibliografias analisadas, o método francês apresenta agilidade por demandar tempo menor para aplicação, sendo interessante sua consideração para os casos em que há grande variação de utilização do pavimento e o comprometimento para a segurança não é tão elevado pela menor velocidade de tráfego (como é o caso das áreas urbanas) ou quando a visão macro é necessária (gerência em nível de rede).

O método utilizado nos Estados Unidos da América é mais aconselhável quando se analisa pavimentos onde a segurança é extremamente importante (como é o caso de pavimentos de aeroportos) ou quando é necessária uma visão detalhada de um trecho viário específico (gerência em nível de projeto).

Considerando-se o caso das normas brasileiras, segundo Fernandes Jr. et al. (2003), as várias revisões do trabalho desenvolvido dentro do SHRP fazem dele um método de avaliação mais confiável do que, por exemplo, os manuais publicados em língua portuguesa (ARB, 1978 e DOMINGUES, 1993). Cabe citar que Domingues (1993) foi um dos trabalhos que subsidiou a Norma DNIT 005/2003-TER, daí presume-se que a confiabilidade das normais brasileiras fica aquém das normas dos EUA. 
Com base nas avaliações das condições do pavimento, será definida a intervenção a ser executada. Portanto, esses dados devem ser coletados de maneira a propiciar uma clara avaliação das causas do defeito e a extensão ou abrangência do mesmo. Também é necessário o conhecimento das restrições existentes para se adotar a solução adequada. Essas restrições podem ser: financeiras, controle de tráfego difícil, vida útil do projeto, elementos geométricos da via, materiais e equipamentos, qualidade e eficiência da mão de obra, outros.

No capítulo 4 é apresentado um Estudo de Caso que correlaciona uma avaliação objetiva de um trecho, efetuada pelo DER/SP/Brasil, a avaliações objetivas e subjetivas, sob a visão dos três países analisados. No capítulo 5 são feitas algumas propostas de adequações das normas brasileiras, no intuito de torná-las mais claras, objetivas e de fácil aplicação. 


\section{CAPÍTULO 4}

\section{ESTUDO DE CASO}

\subsection{Considerações Iniciais}

O trecho de rodovia utilizado para o Estudo de Caso localiza-se em um segmento da SP 253, Rodovia Deputado Cunha Bueno, entre o quilômetro 142,000 e o quilômetro 173,280, ou seja, entre as rodovias SP 330 e SP 255, pertencente à regional de Ribeirão Preto do DER/SP. A pista de rolamento apresenta 7,00 m de largura e os acostamentos são pavimentados. Possui traçado de região ondulada, caracterizada por curvas horizontais de raio médio, interligadas por tangentes. O traçado vertical apresenta rampas com declividades variadas. A região, no geral, apresenta condições geológicas estáveis.

Essa rodovia apresentava pavimento em estado ruim, bastante desgastado, com trincas e deformações permanentes, com panelas ou buracos de várias dimensões e com remendos ao longo de todo o trecho, tanto na pista de rolamento como nos acostamentos pavimentados, necessitando de obras de recuperação. O trecho para Estudo de Caso foi fixado entre o quilômetro 170,300 e o quilômetro 173,300. Este segmento foi considerado suficiente para comparação, tendo em vista que a rodovia apresentava situação bastante homogênea em toda a sua extensão.

O levantamento das condições da via foi efetuado pelo DER/SP em 2008 e o documento final foi emitido em 2009. A escolha do trecho para o Estudo de Caso foi efetuada no final de 2010 e a avaliação completa do local foi efetuada no início de 2012, como complementação e embasamento para as conclusões finais da Dissertação. Vale acrescentar que não houve grande alteração das condições do pavimento neste período, pois as obras de melhorias e serviços de recapeamento da pista e dos acostamentos iniciaram-se em 2010, o que diminuiu, a partir de então, a evolução de deterioração da rodovia. 
Na ocasião do levantamento, a estrutura do pavimento foi identificada como segue:

$\checkmark$ Subleito composto de solo laterítico;

$\checkmark$ Base parcialmente de solo brita e parcialmente de seixo rolado, com espessura média de $14 \mathrm{~cm}$;

$\checkmark$ Capa de rolamento em CBUQ (concreto betuminoso usinado a quente), com espessura entre 4 e $8 \mathrm{~cm}$.

As coletas efetuadas para determinação do tráfego no local chegaram a um valor $\mathrm{N}$ (número de repetições do eixo padrão), para o ano de 2008, de 4,27E+06, e, para o ano de 2018, de 5,04E+07 (projetado). Para a determinação do número de veículos foram encontrados os valores de 1648, para veículos de passeio, 184, para coletivos, 2169, para veículos de carga, totalizando um VDMA (volume diário médio anual) de 4002.

Seguem, na sequência, vários registros dos defeitos existentes, extraídos de Arquivo do DER/SP. Nas Figuras 35 e 36, pode-se ter uma visão geral do trecho do Estudo de Caso, tanto do lado direito como do lado esquerdo. Nas Figuras 37 e 38, seguem detalhes de trincas, buracos e remendos.

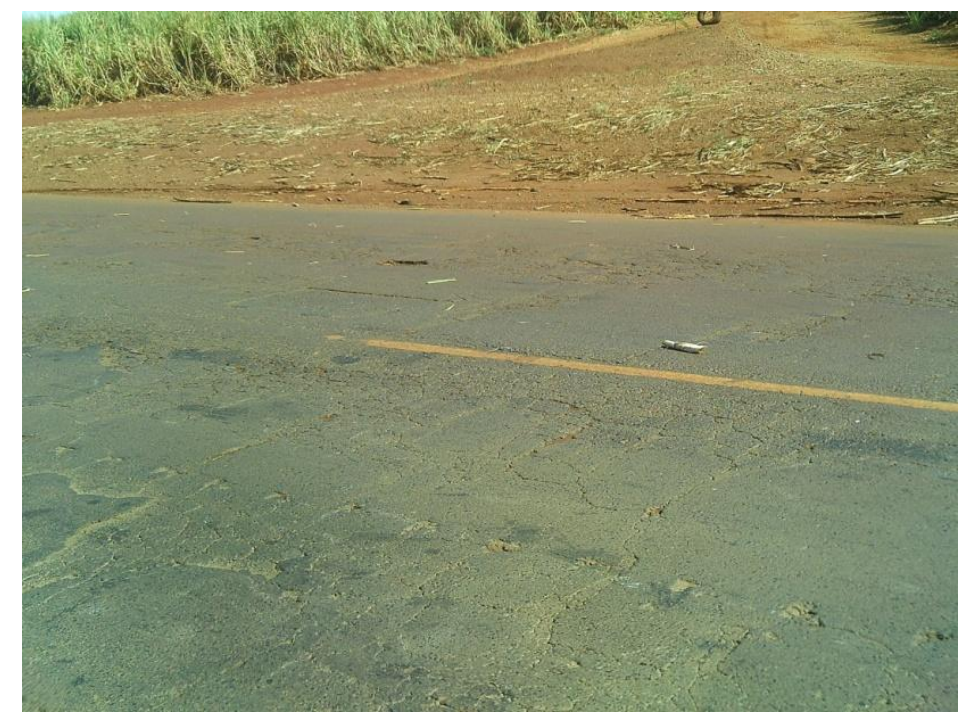

Figura 35 - Vista geral do trecho de Estudo de Caso - lado direito Fonte: Arquivo do DER/SP 


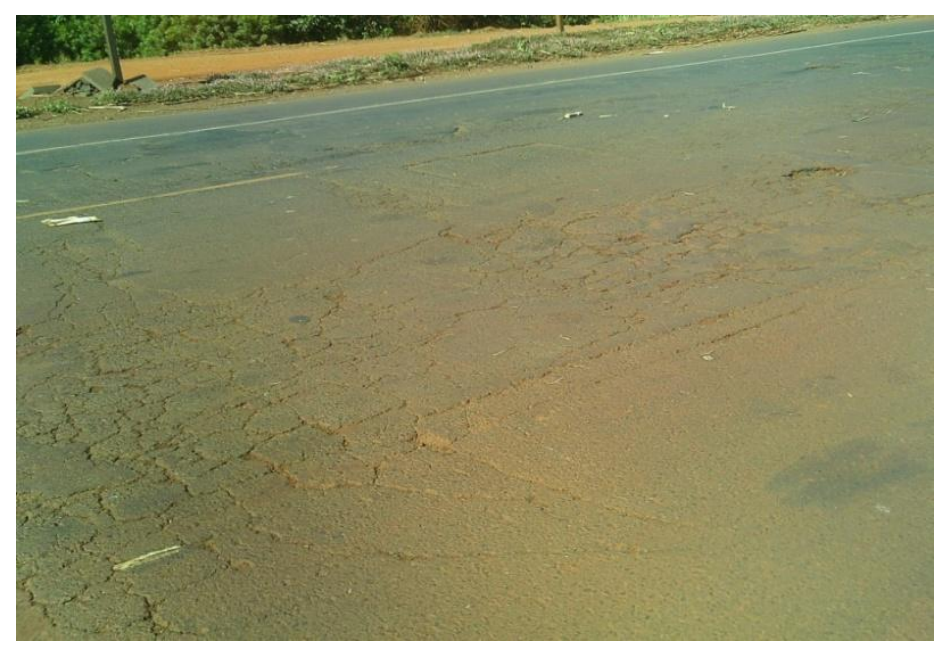

Figura 36 - Vista geral do trecho de Estudo de Caso - lado esquerdo

Fonte: Arquivo do DER/SP

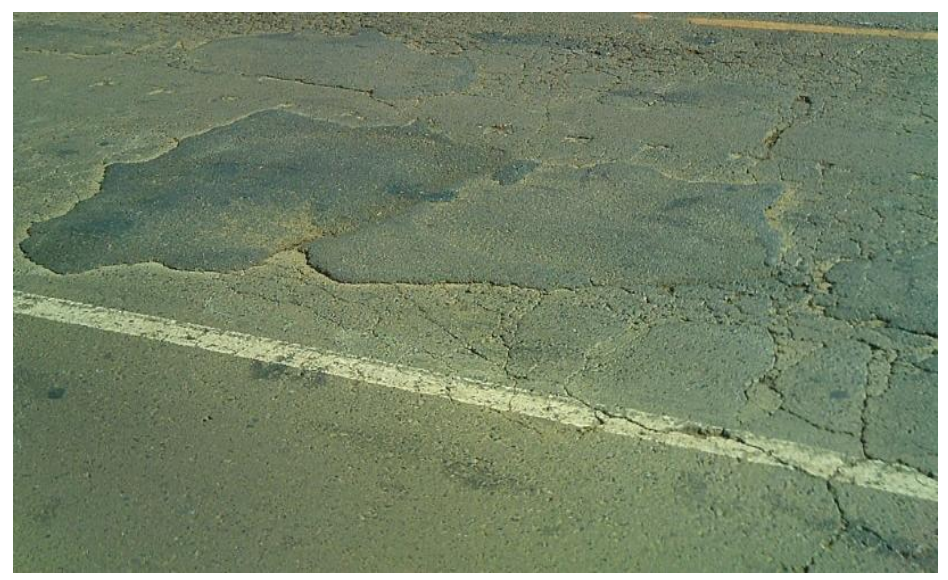

Figura 37 - Remendo de grandes proporções não sanando completamente o problema

Fonte: Arquivo do DER/SP

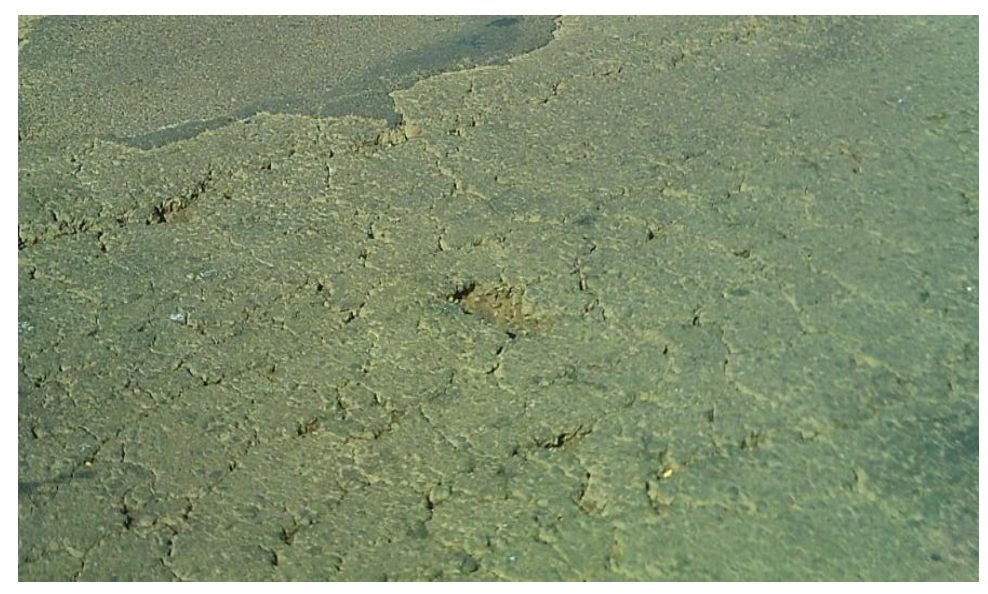

Figura 38 - Detalhe de Trincas por Fadiga com abertura de alguns buracos

Fonte: Arquivo do DER/SP 


\subsection{Avaliações Efetuadas pelo DER/SP com Utilização das Normas do DNER}

Foram feitas, pelo DER/SP, tanto a Avaliação Funcional como o Levantamento Estrutural, com a finalidade de selecionar as atividades de manutenção e reabilitação a serem desenvolvidas no segmento viário analisado.

\subsection{1 - Avaliações Funcionais com a utilização da DNER-PRO 008/94}

Para efeito de avaliação foram considerados os seguintes tipos de defeitos (DNIT 005/2003):

$\checkmark$ Tipo 1 - Trincas Classe 1 (FC-1) - FI (fissuras), TTC (trincas transversais curtas), TTL (trincas transversas longas), TLC (trincas longitudinais curtas), TLL (trincas longitudinais longas) e TRR (trincas de retração ou do revestimento);

$\checkmark$ Tipo 2 - Trincas Classe 2 (FC-2) - J (trincas interligadas tipo 'jacaré’) e TB (trincas nos bordos);

$\checkmark$ Tipo 3 - Trincas Classe 3 (FC-3) - JE (trincas interligadas com erosão tipo 'jacaré') e TBE (trincas nos bordos com erosão);

$\checkmark$ Tipo 4 - Afundamento (ALP - afundamento plástico local e ATP - afundamento plástico na trilha de roda);

$\checkmark$ Tipo 5 - Ondulações e Panelas (O e P);

$\checkmark$ Tipo 6 - Exsudação (EX);

$\checkmark$ Tipo 7 - Desgaste (D);

$\checkmark$ Tipo 8 - Remendos (R).

A Avaliação Funcional ou Avaliação Objetiva da Superfície de Pavimentos Flexíveis foi realizada nas duas faixas de rolamento, lado direito e lado esquerdo, do trecho em estudo. Para essa avaliação, foi utilizada a Norma DNER-PRO-008/94, que embasou a elaboração revisada da Norma DNIT 006/2003-PRO, que faz parte da bibliografia deste trabalho. A treliça utilizada para medição das flechas nas trilhas de roda, atualmente, é normatizada pela DNIT 007/2003-PRO. 
A Avaliação efetuada pelo DER consistiu na observação dos defeitos existentes em estações de ensaio com seis metros de extensão e largura igual a três metros e meio (faixa de rolamento no local) e determinação das flechas, em milímetros, nas trilhas de roda externa e interna. Note-se que a DNIT 006/2003-PRO determina 3,00 m antes e 3,00 m depois de cada estação.

Para o trecho em estudo, o espaçamento entre as superfícies da avaliação (de extensão de $6,00 \mathrm{~m}$ ) foi de 40 metros, alternados em relação ao lado da pista de rolamento, ou seja, de 80 em 80 metros em cada lado, direito e esquerdo. As flechas nas trilhas de roda foram medidas em milímetros, em todas as estações de ensaio, tanto na trilha interna como na externa, utilizando a treliça metálica de medições. Note-se que a DNIT 006/2003-PRO indica espaçamento de 20 metros, alternados em relação ao lado da pista de rolamento, ou seja, 40 em 40 metros em cada lado. Assim sendo, a avaliação efetuada abrangeu metade das estações do que abrangeria caso obedecesse rigorosamente à norma do DNIT. Essa situação foi considerada suficiente pelo fato do pavimento apresentar homogeneidade nas suas faixas de rolamento.

No relatório elaborado pelo DER/SP, foram apresentados resultados dos levantamentos realizados no campo, assim como o cálculo do IGG (Índice de Gravidade Global), para cada segmento homogêneo. O segmento fixado para o Estudo de Caso, ou seja, entre o quilômetro 170,300 e o quilômetro 173,300, apresentou os seguintes valores de IGG, todos eles considerados como de condição 'RUIM':

$\checkmark$ 170,3 a 171,3 - lado esquerdo - IGG $=117,71 / 129,88$ (esse trecho abrange dois segmentos avaliados por esse motivo apresenta dois valores de IGG)

$\checkmark 172,3$ a $173,3-$ lado direito - IGG $=130,03$

Note-se que a determinação do IGG envolve várias aproximações, o que torna o valor obtido pouco preciso. Assim sendo, um comentário que se pode fazer, neste trabalho, é que não se faz necessário que os valores de IGG sejam apresentados com duas casas decimais. 


\subsection{2 - Levantamento Estrutural com a utilização da Viga Benkelman}

O Levantamento Estrutural, ou Avaliação Estrutural, foi realizado com o emprego da Viga Benkelman, aparelho destinado a medir deflexões em pavimentos. Foram utilizadas as normas DNER-PRO-11/79 e DNER-PRO-269/94 para cálculo das deflexões e atribuições de qualidades ao trecho analisado. $\mathrm{O}$ espaçamento entre as superfícies de avaliação também foi de 40 metros, alternados em relação ao lado da pista de rolamento, ou seja, de 80 em 80 metros em cada lado, direito e esquerdo.

No relatório elaborado pelo DER/SP, foram apresentados resultados dos levantamentos com relação à capacidade estrutural da rodovia neste trecho. $\mathrm{O}$ segmento fixado para o Estudo de Caso apresentou os seguintes resultados:

$\checkmark$ 170,3 a 171,3 - lado esquerdo - foi classificado como tendo 'qualidade estrutural má ou ruim', sendo recomendado reforço ou reconstrução do pavimento;

$\checkmark 172,3$ a 173,3 - lado direito - foi classificado como tendo 'qualidade estrutural regular', sendo recomendado reforço do pavimento.

\subsection{Avaliações Efetuadas no Estudo de Caso}

A intenção destas avaliações foi comparar os resultados obtidos pelo DER/SP, ao analisar a rodovia do Estudo de Caso, com os resultados obtidos com a utilização: de normas do DNIT (DNIT 008/2003 e DNIT 009/2003), do conceito de Índice de Condição do Pavimento, das normas francesas.

\subsection{1 - Levantamento Visual Contínuo (Norma DNIT 008/2003-PRO)}

Para essa avaliação foram mensurados e analisados os trechos escolhidos com a finalidade de se obter o IGGE, o ICPF e o IES. No caso da determinação do IGGE, a Norma DNIT 008/2003-PRO leva em consideração somente os defeitos: Trincas por Fadiga, Deformação Permanente, Buracos (ou Panelas) e Remendos. 
No primeiro segmento, lado esquerdo (LE), foram encontrados os valores de: $30 \%$ da área com trincas por fadiga, $25 \%$ da área com deformações permanentes, 15 (quinze) remendos, nenhum buraco. No segundo segmento, lado direito (LD), foram encontrados os valores de: $40 \%$ da área com trincas por fadiga, $25 \%$ da área com deformações permanentes, 5 (cinco) buracos, 15 (quinze) remendos.

A cada uma das frequências são atribuídos códigos: A - alta, M - média, B - baixa. A cada uma dessas frequências também são atribuídos fatores: Fpr - relativo a panelas e remendos, Foap - relativo a deformações, Ft - relativo a trincas. E a cada defeito é atribuído um peso: Ppr - relativo a panelas e remendos, Poap - relativo a deformações, $\mathrm{Pt}$ - relativo a trincas. Esses valores encontram-se todos definidos em tabelas de norma. As tabelas que são utilizadas foram extraídas da Norma DNIT 008/2003-PRO e encontram-se no Anexo 3, página 109. Através do uso dessas tabelas, a frequência (encontrada em campo) das trincas, das deformações, das panelas e dos remendos, é correlacionada a esses códigos, fatores e pesos, conforme apresentado na Tabela 4.

Tabela 4 - Valores dos elementos colhidos em campo para cálculo do IGGE, correlacionados aos códigos, aos fatores e aos pesos

\begin{tabular}{|c|c|c||}
\hline $\begin{array}{c}\text { Segmentos Avaliados do Trecho em } \\
\text { Estudo }\end{array}$ & $\begin{array}{c}170,300-171,300 \\
(\mathrm{LE})\end{array}$ & $\begin{array}{c}172,300-173,300 \\
(\mathrm{LD})\end{array}$ \\
\hline \hline Frequência de Trincas & $30 \%-$ código M & $40 \%$ - código M \\
\hline Frequência de Deformações & $25 \%$ - código M & $25 \%$ - código M \\
\hline Frequência de Panelas e Remendos & $15^{*}-$ código A & $20 * *$ - código A \\
\hline Fator Ft & 30 & 40 \\
\hline Fator Foap & 25 & 25 \\
\hline Fator Fpr & 15 & 0,45 \\
\hline Pt & 0,45 & 0,70 \\
\hline Poap & 0,70 & 1,00 \\
\hline Ppr & 1,00 & 20 \\
\hline
\end{tabular}

* O número 15 foi encontrado somando-se o número de buracos e remendos $(0+15)$ ** O número 20 foi encontrado somando-se o número de buracos e remendos $(5+15)$ 
Aplicando-se a fórmula para o cálculo do IGGE:

$\mathrm{IGGE}=(\mathrm{Pt} \times \mathrm{Ft})+(\mathrm{Poap} \times$ Foap $)+(\mathrm{Ppr} \times \mathrm{Fpr})$

São obtidos os seguintes valores:

1) Trecho 170,3 a 172,3 (lado esquerdo):

$\mathrm{IGGE}=(0,45 \times 30)+(0,70 \times 25)+(1,00 \times 15)=46$

2) Trecho 172,3 a 173,3 (lado direito):

$\operatorname{IGGE}=(0,45 \times 40)+(0,70 \times 25)+(1,00 \times 20)=57,5$

Para a determinação do ICPF, a Norma DNIT-008/2003-PRO leva em conta todos os defeitos que constam na Norma DNIT-005/2003-TER. O valor de ICPF, para o Estudo de Caso, pode ser apenas estimado, tendo em vista o fato de o avaliador ter sido único, quando o sugerido por norma é o número mínimo de dois avaliadores. A nota atribuída, levando-se em conta a severidade e extensão dos defeitos existentes e considerando-se a tabela específica para determinação do ICPF através da Norma DNIT-008/2003-PRO, foi 2 (dois).

Assim sendo, pela Tabela 3, a esses valores de IGGE e ICPF corresponde um valor de IEF igual a 5 (cinco), ou seja, um conceito RUIM. Essa constatação é a mesma que foi obtida pelo DER na avaliação funcional efetuada.

Para uma avaliação mais precisa é necessário o rígido atendimento de todas as orientações da DNIT 008/2003-PRO. Isso inclui o preenchimento de todos os anexos da mesma e de medidas criteriosas das extensões das degradações existentes no local analisado.

Um aspecto positivo é que o LVC não se trata de uma Avaliação estritamente objetiva, mas alia um pouco da Avaliação Objetiva (valores de IGGE) com a Avaliação Subjetiva (valores de ICPF). Isso pode ser muito útil, pois leva em consideração o item 'segurança' aliado ao item 'conforto'. 
Por outro lado, um ponto negativo é que as panelas (buracos) e os remendos são avaliados somente em sua quantidade, não sendo levado em conta nem sua extensão nem sua severidade.

\subsection{2 - Avaliação com a utilização do conceito de Índice de Condição do Pavimento $(I C P)$}

A concepção deste índice é quantificar a condição do pavimento através de uma equação que utiliza valores de extensão, nível de severidade e fator de ponderação dos defeitos. Ao valor de ICP igual a 100 atribui-se um pavimento em perfeitas condições. A equação é a que segue (simplificação da equação da página 74); onde Dij e fij são extensão e fator de ponderação do defeito i com nível de severidade j:

$$
\mathrm{ICP}=100-\sum_{\mathrm{ij}} \sum_{\mathrm{ij}} \mathrm{Dij} \times \mathrm{f} \mathrm{ij}
$$

A planilha para preenchimento desta avaliação deve apresentar o local, com detalhamento, e as condições do pavimento. São atribuídos valores de Pontos Dedutíveis para serem diminuídos da nota máxima 100 para um pavimento sem nenhuma deterioração.

Esse tipo de conceito permite uma liberdade maior de avaliação, pois os valores de ponderação podem ser aplicados de acordo com a situação com a qual se está trabalhando, ou seja, conforme o tipo de rodovia, de tráfego, de pavimento e de defeitos que surgiram no local analisado. Podem ser considerados todos os defeitos com os fatores de ponderação indicados em bibliografia citada (FERNANDES et al., 2003). Podem ser considerados todos os defeitos com os fatores de ponderação com igual valor. Podem ser atribuídos valores apenas aos defeitos que ocorrem no trecho considerado, atribuindo-se pontos dedutíveis ao valor máximo de 100 , tendo em vista maior ou menor importância e severidade de cada um desses defeitos. Neste Estudo de Caso foi escolhida a terceira opção pela maior facilidade e compatibilidade de aplicação da mesma. 
Para os defeitos Trinca por Fadiga e Deformação Permanente foi escolhido o valor de 13 pontos dedutíveis por estarem em grande parte do pavimento, mas apresentarem severidade moderada. Para o defeito Desnível Pista Acostamento foi escolhido o valor 1 por se apresentar em pequena parte do trecho escolhido e com baixa severidade. Para os defeitos Buraco (ou Panela) e Remendo foi escolhido o valor de 13 pontos dedutíveis por estarem em grande parte do pavimento e apresentarem severidade alta.

Embora o pavimento estivesse envelhecido, não foi possível detectar Desgaste nos trechos estudados devido à presença de muitas trincas e muitos remendos em toda a extensão da rodovia.

A Figura 39, extraída do Arquivo do DER/SP, ilustra um local do trecho em obras, no momento da operação de interrupção de tráfego em um dos sentidos, onde é possível se verificar a quantidade bastante elevada de veículos pesados, situação esta que pode ter propiciado a aceleração das Trincas por Fadiga e Deformação Permanente.

Para os trechos estudados, a determinação do ICP é apresentada nas Tabelas 5 e 6.

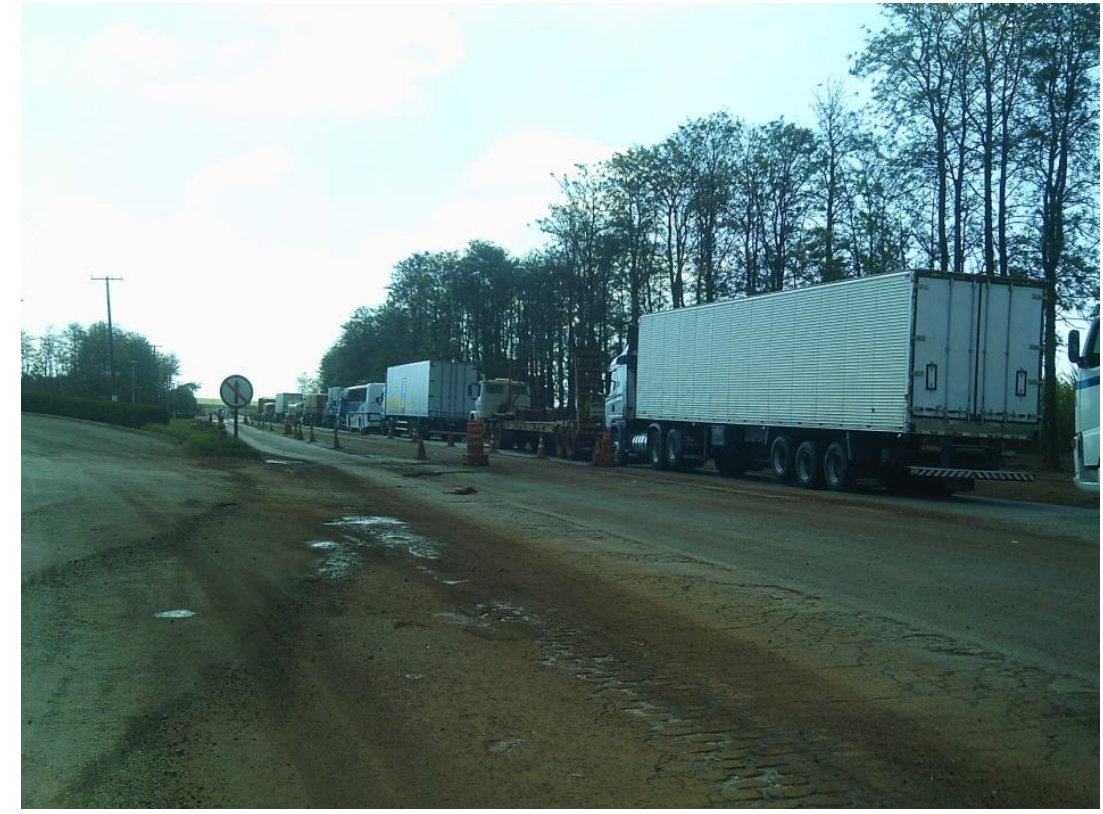

Figura 39 - Elevada ocorrência de veículos pesados na via utilizada no Estudo de Caso Fonte: Arquivo do DER/SP 
Tabela 5 - Cálculo do ICP com pontos dedutíveis atribuídos em função da severidade e extensão: Trecho I (170,300 a 171,300 - LE)

\begin{tabular}{|c|c|c|}
\hline DEFEITOS & INTERVALO & PONTOS DEDUTÍVEIS \\
\hline Trincas por Fadiga & $0-20$ & 13 \\
\hline Trincas em Blocos & $0-5$ & 0 \\
\hline Trincas nos Bordos & - & 0 \\
\hline Trincas Longitudinais & $0-5$ & 0 \\
\hline Trincas por Reflexão & - & 0 \\
\hline Trincas Transversais & - & 0 \\
\hline Remendos & $0-15$ & 13 \\
\hline Panelas & $0-15$ & 0 \\
\hline Deformação Permanente & $0-20$ & 13 \\
\hline Corrugação & - & 0 \\
\hline Exsudação & - & 0 \\
\hline Agregados Polidos & - & 0 \\
\hline Desgaste & $0-10$ & 0 \\
\hline Desnível Pista Acostamento & $0-5$ & 1 \\
\hline Bombeamento & $0-5$ & 0 \\
\hline
\end{tabular}

Tabela 6 - Cálculo do ICP com pontos dedutíveis atribuídos em função da severidade e extensão: Trecho II (172,300 a 173,300 - LD)

\begin{tabular}{|l|c|c|}
\hline \multicolumn{1}{|c|}{ DEFEITOS } & INTERVALO & PONTOS DEDUTÍVEIS \\
\hline Trincas por Fadiga & $0-20$ & 13 \\
\hline Trincas em Blocos & $0-5$ & 0 \\
\hline Trincas nos Bordos & - & 0 \\
\hline Trincas Longitudinais & $0-5$ & 0 \\
\hline Trincas por Reflexão & - & 0 \\
\hline Trincas Transversais & - & 0 \\
\hline Remendos & $0-15$ & 13 \\
\hline Panelas & $0-15$ & 13 \\
\hline Deformação Permanente & $0-20$ & 13 \\
\hline Corrugação & - & 0 \\
\hline Exsudação & - & 0 \\
\hline Agregados Polidos & - & 0 \\
\hline Desgaste & $0-10$ & 0 \\
\hline Desnível Pista Acostamento & $0-5$ & 1 \\
\hline Bombeamento & $0-5$ & 0 \\
\hline
\end{tabular}




$$
\begin{aligned}
& \text { ICP }(\text { tabela } 5)=100-(13+13+13+1)=60, \text { para o lado esquerdo; } \\
& \text { ICP }(\text { tabela } 6)=100-(13+13+13+13+1)=47 \text {, para o lado direito. }
\end{aligned}
$$

Para o Trecho I foi encontrado o valor de 60. Para o Trecho II foi encontrado o valor de 47. Ambos solicitando Recapeamento, conforme os limites citados (FERNANDES et al., 2003):

$\checkmark \quad 0$ a $30=$ reconstrução;

$\checkmark 30$ a $80=$ recapeamento;

$\checkmark$ acima de $80=$ manutenção adequada a cada caso.

Ou considerados como regular (lado esquerdo) e ruim (lado direito), conforme os limites adotados por Lopes et al. (2008):

$$
\begin{aligned}
& \checkmark \quad 0 \text { a } 30=\text { muito ruim; } \\
& \checkmark \quad 30 \text { a } 50=\text { ruim; } \\
& \checkmark \quad 50 \text { a } 70=\text { regular; } \\
& \checkmark \quad 70 \text { a } 90=\text { bom; } \\
& \checkmark \quad 90 \text { a } 100=\text { muito bom. }
\end{aligned}
$$

Esse tipo de avaliação apresenta a vantagem de ser bastante ágil e objetivo, quando comparado, por exemplo, com o LVC, podendo auxiliar no gerenciamento em nível de rede.

\subsection{3 - Avaliação Subjetiva (Norma DNIT-009/2003-PRO)}

A avaliação subjetiva aplicada para o Estudo de Caso pretende correlacionar essa análise com as efetuadas nos itens 4.3.1 (LVC) e 4.3.2 (ICP), e, ainda, com os valores encontrados pelo DER quando este efetuou a avaliação objetiva do trecho. Essa avaliação é semelhante à avaliação subjetiva utilizada pelos EUA. Para essa Avaliação Subjetiva, usa-se a norma DNIT 009/2003 - PRO. 
O trecho foi analisado durante cinco dias diferentes, no início do mês de março de 2012, com boas condições de tráfego, considerando-se que a sensibilidade para o trabalho foi atendida, tendo em vista que a observadora é funcionária há mais de vinte anos do Departamento de Estradas de Rodagem lidando com a conservação do pavimento rodoviário. Os segmentos do trecho avaliado eram de aspecto uniforme e de pequena extensão. Foram anotados os valores encontrados de maneira homogênea, considerando-se a situação no momento da avaliação. Para evitar distorções, foram escolhidos segmentos sem interferências (variações de geometria, cruzamentos rodoferroviários, bueiros, outros).

Adotando a mesma nomenclatura do levantamento efetuado pelo DER/SP, entende-se que os trechos deveriam ter atribuições de notas da seguinte maneira:

$\checkmark$ segmento 170,300-171,300 (lado esquerdo): nota 2-3 (condição regular)

$\checkmark$ segmento 172,300-173,300 (lado direito): nota 1-2 (condição ruim)

Essas variações de valores têm a intenção de abranger o fato de o pavimento ter sido avaliado por apenas um profissional.

\subsection{4 - Avaliação Visual utilizando as Normas Francesas}

As Normas Francesas levam em consideração a divisão entre os defeitos de origem estrutural (tipo A) e os defeitos de outras origens (tipo B). As degradações do tipo A geram trabalhos importantes do tipo reforço das camadas de superfície.

Primeiramente é determinado o Índice de Fissuração (IF), que depende da gravidade e da extensão das Trincas por Fadiga. No Estudo de Caso, para ambos os lados, a extensão das trincas ficou entre 10 e $50 \%$ (Tabela 4) e a gravidade foi considerada moderada (citado no item 4.3.2 relativo à determinação do ICP). Em seguida é determinado o Índice de Deformação, que depende da gravidade e da extensão das Deformações Permanentes. 
Para ambos os lados, a extensão das deformações ficou, novamente, entre 10 e $50 \%$ (Tabela 4) e a gravidade foi considerada, novamente, moderada (citado no item 4.3.2). A combinação desses índices resulta em um primeiro valor de Nota de Degradação. Esse valor pode ser corrigido em função da gravidade e da extensão dos remendos. A quantidade dos remendos foi de 15 ocorrências para ambos os lados, o que corresponde, aproximadamente, ao intervalo de frequência entre 10 e $50 \%$. A gravidade, nesse caso, foi considerada alta (item 4.3.2).

Tendo em vista a situação encontrada em campo, acima detalhada, foram determinados valores através das Tabelas 7 - 8 - 9 - 10, todas elaboradas a partir das orientações da bibliografia que detalha o método VIZIR (AUTRET, P.; BROUSSE, J.L.; 2001). O Anexo 4, página 110, apresenta os quadros que orientam o cálculo do Índice de Degradação de Superfície.

Tabela 7 - Determinação do IF

\begin{tabular}{|c|c|c|c|c|}
\hline \multirow{4}{*}{$\begin{array}{c}\text { Índice de } \\
\begin{array}{c}\text { Fissuração } \\
\text { (IF) igual a }\end{array}\end{array}$} & $\begin{array}{r}\text { extensão } \\
\text { gravidade }\end{array}$ & $\begin{array}{c}0 \text { a } 10 \\
\%\end{array}$ & $\begin{array}{c}10 \text { a } 50 \\
\%\end{array}$ & $\begin{array}{c}\text { acima } \\
\text { de } 50 \%\end{array}$ \\
\cline { 2 - 5 } & 2 (baixa) & 1 & 2 & 3 \\
\cline { 2 - 5 } & 3 (moderada) & 2 & 3 & 4 \\
\hline
\end{tabular}

Tabela 8 - Determinação do ID

\begin{tabular}{|c|c|c|c|c|}
\hline \multirow{4}{*}{$\begin{array}{c}\text { Índice de } \\
\text { Deformação } \\
\text { (ID) igual a }\end{array}$} & $\begin{array}{c}\text { extensão } \\
\text { gravidade }\end{array}$ & $\begin{array}{c}0 \text { a } 10 \\
\%\end{array}$ & $\begin{array}{c}10 \text { a } 50 \\
\%\end{array}$ & $\begin{array}{c}\text { acima } \\
\text { de } 50 \%\end{array}$ \\
\cline { 2 - 6 } & 2 (baixa) & 1 & 2 & 3 \\
\cline { 2 - 6 } & 3 (moderada) & 2 & 3 & 4 \\
\hline
\end{tabular}


Tabela 9 - Determinação da Primeira Nota de Degradação

\begin{tabular}{|c|c|c|c|c|c|}
\hline \multirow{5}{*}{$\begin{array}{c}\text { Primeira } \\
\text { Nota de } \\
\text { Degradação } \\
5\end{array}$} & IF & 0 & $1-2$ & 3 & $4-5$ \\
\hline & 0 & 1 & 0 & 3 & 4 \\
\hline & $1-2$ & 3 & 3 & 4 & 5 \\
\hline & 3 & 4 & 5 & 5 & 6 \\
\hline & $4-5$ & 5 & 6 & 7 & 7 \\
\hline
\end{tabular}

Tabela 10 - Correção para Reparação

\begin{tabular}{|c|c|c|c|c|}
\hline \multirow{4}{*}{$\begin{array}{c}\text { Correção } \\
\text { para }\end{array}$} & gravidade & $\begin{array}{c}0 \text { a } 10 \\
\%\end{array}$ & $\begin{array}{c}10 \text { a } 50 \\
\%\end{array}$ & $\begin{array}{c}\text { acima } \\
\text { de } 50 \%\end{array}$ \\
\cline { 2 - 5 } & 1 (baixa) & 0 & 0 & 0 \\
\hline \begin{tabular}{c} 
Reparação \\
\cline { 2 - 5 }
\end{tabular} & 2 (moderada) & 0 & 0 & +1 \\
\cline { 2 - 5 } & 3 (alta) & 0 & +1 & +1 \\
\hline
\end{tabular}

\section{Valor do Índice de Degradação Final = $5+1=6$}

A este valor de IS (6) é atribuída a classificação RUIM, necessitando grandes trabalhos de manutenção ou de reforço. É importante relembrar que essa classificação de 1 a 7 é desnecessária, pois os estados visuais são agrupados em apenas três: bom, médio e ruim.

\subsection{Comparações entre os Resultados Obtidos}

O trabalho elaborado pelo DER/SP apresentou resultados muito semelhantes ao trabalho desenvolvido no Estudo de Caso. Tanto o levantamento de defeitos através da Avaliação Objetiva, baseada no cálculo do IGG, quanto o levantamento do estado estrutural do pavimento, através da utilização da viga Benkelman, indicaram um segmento de baixa qualidade, necessitando de trabalhos de recuperação e reforço. 
A superfície do lado direito apresentou IGG de maior valor. Em compensação, a estrutura do lado esquerdo apresentou maior deterioração. Esse trabalho demandou um levantamento amplo, considerando todos os defeitos existentes nas normas, e demandou uma série de cálculos para ser concluído.

O procedimento utilizado no item 4.3.1 levou em consideração os defeitos estruturais, de acordo com a norma francesa, para a determinação do IGGE, ou seja, as trincas por fadiga, as deformações permanentes e os remendos. No cálculo também são contabilizados os buracos. Assim sendo, a elaboração da Tabela 4 e os cálculos do IGGE demandaram menor tempo. Salienta-se que a determinação do ICPF, este com avaliações de todos os defeitos indicados na Norma DNIT-005/2003-TER, poderia ser mais precisa com um número maior de avaliadores. A nota final (IEF) levou a mesma conclusão do levantamento do DER/SP, ou seja, necessidade de recuperação e reforço, tendo em vista a qualidade RUIM apresentada pelo pavimento. A Avaliação Objetiva com a utilização do ICP (item 4.3.2) consegue abranger os defeitos de maneira ampla e, ao mesmo tempo, demandar um trabalho menor e mais ágil. A conclusão foi a mesma: necessidade de recapeamento. A Avaliação Subjetiva do item 4.3.3 levou ao mesmo resultado, destacando-se que a avaliação tende a apresentar melhores resultados (menor desvio-padrão) quanto maior o número de avaliadores, sem se esquecer, no entanto, que o maior número de avaliadores significa custos maiores.

O modo de avaliar através dos métodos utilizados na França, item 4.3.4, que alia a agilidade dos itens 4.3.1 e 4.3.2 (LVC e ICP), não foi prejudicada com a participação de um único avaliador. Esse levantamento visual considera valores numéricos e não se baseia numa avaliação subjetiva do(s) avaliador(es) a respeito da qualidade de rolamento, embora ainda dependa do 'bom senso' do 'observador'. Esse método pode ser uma ferramenta valiosa para uma avaliação preliminar por ser muito ágil e fácil de aplicar. Na sequência, o capítulo 5 traz algumas sugestões para melhoria no tratamento dado à Gerência de Pavimentos no Brasil. 


\section{CAPÍTULO 5}

\section{CONCLUSÕES}

Existem algumas incoerências e inconsistências nas normas brasileiras quanto à definição de alguns defeitos, o que pode levar a dúvidas ou dificuldades no momento da avaliação (quantificação da extensão e determinação do nível de severidade). Alguns aspectos podem ser melhorados, mediante incorporação e adaptação de aspectos das normas norte-americanas e francesas, visando a definição clara e simples dos defeitos e, consequentemente, a obtenção de normas brasileiras mais eficientes.

A Trinca (ou trincamento), apesar de sua grande importância, não é tão detalhada nas normas brasileiras quanto nas normas dos EUA e da França. As normas francesas, por exemplo, distinguem a trinca por fadiga das demais trincas. A Trinca por Fadiga é considerada defeito estrutural enquanto que as demais são consideradas defeitos de origem outra que não estrutural (trincas em blocos, nos bordos, transversais ou longitudinais). A Trinca Longitudinal, quando surge na trilha de roda, pode ter origem estrutural. Cabe ressaltar, também, que a subdivisão das trincas por fadiga (por envelhecimento e por reflexão), apresentada no Manual do DNIT, é confusa e muda conceitos já reconhecidos como adequados, sendo conveniente sua eliminação.

Agrupar os defeitos Corrugação e Escorregamento, a exemplo do que fazem as normas estrangeiras estudadas, poderá deixar as normas brasileiras mais claras e simples, facilitando a identificação do tipo e do nível de severidade do defeito, e, consequentemente, a adequada seleção da atividade de manutenção e reabilitação a ser executada.

Para a norma francesa, as panelas podem ter origens variadas e devem ser corrigidas imediatamente, enquanto o remendo é classificado como defeito estrutural. No Manual do programa SHRP também há distinção entre remendos e panelas, tanto que as seções-teste foram monitoradas continuamente, com registro dos remendos e das panelas (ou buracos) mesmo quando a correção das panelas era feita imediatamente. 
As normas brasileiras, no cálculo do IGGE (Norma DNIT-008/2003-PRO), agrupam os defeitos Panelas (buracos) e Remendos, conforme apresentado no Estudo de Caso, o que pode comprometer a avaliação, pois nem sempre um remendo é executado para tapar uma panela. É importante ressaltar que o Levantamento Visual Contínuo, que não avalia a extensão de remendos e buracos, mas apenas a sua quantidade, pode levar a distorções por também não avaliar a severidade.

As definições das três normas se complementam, assim sendo, o Manual do DNIT apresentaria definições mais claras e completas se aliasse as definições dos três países, com as devidas adaptações sugeridas neste trabalho, para eliminar as incoerências e complexidades hoje existentes nas normas nacionais.

Analisando-se a maneira como os defeitos em pavimentos surgem e evoluem, é de grande importância, para a gerência de pavimentos no Brasil, classificar e avaliar os pavimentos considerando a diferenciação entre defeitos estruturais e não estruturais. $\mathrm{O}$ tratamento diferenciado, conforme as normas francesas fazem, facilita o levantamento dos defeitos e auxilia nas tomadas de decisões. Saber se o defeito é causado ou não por problemas estruturais pode evitar avaliações estruturais caras e desnecessárias e auxiliar até mesmo a impedir sua ocorrência no futuro, por ajudar na previsão dos locais onde é maior a probabilidade de sua ocorrência.

O levantamento inicial, em nível de rede ('macro'), é capaz de definir se um determinado trecho viário apresenta defeitos estruturais ou não. É o ponto de partida e a principal forma de avaliação para a gerência de pavimentos urbanos.

Em relação à gerência de pavimentos em nível de projeto, as normas norte-americanas são objetivas e precisas, o que também ocorre quando se trata de pavimentos de aeroportos. Deveriam, portanto, ser referência para o Manual do DNIT quanto à determinação da severidade e extensão dos defeitos. 
Por outro lado, as normas francesas apresentam a inconveniência de utilizar alguns termos como, por exemplo, 'trincas claramente abertas', que deixam margens a diferentes interpretações por diferentes avaliadores, com relação à gravidade dos defeitos. Vale, aqui, salientar que os níveis de severidade do defeito Desnível entre pista e acostamento são citados somente nas normas da França, devendo ser considerados esses níveis para uma futura classificação geral no Brasil.

A determinação de um Índice de Condição de Pavimento (ICP) possibilita a definição, com bastante objetividade, através do uso de uma árvore de decisão, da estratégia de intervenção mais indicada. Quanto à determinação dos pontos dedutíveis, utilizados para o cálculo do ICP, são definidos maiores intervalos de valores para os defeitos estruturais, ou seja, trincas por fadiga e deformação permanente das trilhas de roda. Também é atribuído um valor alto aos remendos (também considerado defeito estrutural) e às panelas. Embora o desgaste não tenha sido identificado no Estudo de Caso, apesar de ter precedido a ocorrência de muitos dos defeitos encontrados, seu intervalo de valores também deve ser elevado.

Após a avaliação inicial de toda a rede, a frequência de novas avaliações deve ser maior para pavimentos submetidos a cargas mais pesadas e a um fluxo mais intenso, sugerindo-se periodicidade anual de levantamentos de defeitos. Por outro lado, vias com tráfego leve, sem evidências de problemas estruturais, podem ser avaliadas a cada três anos.

Assim sendo, a revisão e a reorganização das normas brasileiras, poderia considerar, especialmente, os pontos relacionados a seguir:

$\checkmark$ detalhar melhor o defeito Trincamento, com destaque para a Trinca por Fadiga, como defeito da estrutura do pavimento (a trinca longitudinal também pode ser enquadrada como defeito estrutural quando surge na trilha de roda);

$\checkmark$ excluir do Manual do DNIT a subdivisão de trincas por fadiga, por envelhecimento e por reflexão, por modificar, equivocadamente, conceitos já reconhecidos; 
$\checkmark$ agrupar os defeitos corrugação e escorregamento em um único defeito;

$\checkmark$ tratar especialmente o defeito Remendo, que também é uma conservação de superfície, mas que não deixa de ser uma indicação de local que vai merecer atenção, sempre, quando por ocasião das avaliações;

$\checkmark$ utilizar o defeito Panela (Buraco) nas avaliações pelo fato de sua alta ocorrência, ainda, em pavimentos brasileiros;

$\checkmark$ considerar os níveis de severidade e a extensão (área ou comprimento) em todos os casos, no momento da avaliação e quantificação;

$\checkmark$ complementar as definições dos defeitos nas normas brasileiras com as definições utilizadas nos outros países;

$\checkmark$ classificar os defeitos com a separação entre defeitos de origem estrutural e defeitos de origens diversas;

$\checkmark$ considerar avaliações diferenciadas para as diversas condições e para os diversos locais, sendo mais adequadas as normas dos Estados Unidos para o caso de aeroportos e para avaliações em nível de projeto, e as normas da França para o caso de pavimento urbano e para avaliações em nível de rede;

$\checkmark$ utilizar o conceito de ICP.

Essas considerações poderão resultar em um método de avaliação da condição dos pavimentos mais ágil, simples e eficiente, proporcionando, em última análise, pavimentos de rodovias, vias urbanas e aeroportos com maior segurança, conforto e economia, objetivo que motivou este trabalho de pesquisa. 


\section{REFERÊNCIAS BIBLIOGRÁFICAS}

ARB (1978). Catálogo dos Defeitos dos Revestimentos dos Pavimentos. Associação Rodoviária Brasileira. Traduzido por Hugo Alves Pequeno. São Paulo

AUTRET, P.; BROUSSE, J.L. (2001). Vizir, Método com apoio de computador para a estimativa das necessidades de conservação de uma rede rodoviária. Laboratoires Central des Ponts et Chaussées, LCPC.

BERNUCCI, L.B.; MOTTA, L.M.G.; CERRATI, J.A.P.; SOARES, J.B. (2007). Pavimentação Asfáltica, Formação Básica para Engenheiros. Associação Brasileira das Empresas Distribuidoras de Asfalto, ABEDA.

CAREY, W.N.; IRICK, P.E. (1960). The Pavement Serviceability-Performance Concept. Highway Research Board Bulletin 250, pp. 40-58.

DANIELESKI, M.L. (2004). Proposta de Metodologia para Avaliação Superficial de Pavimentos Urbanos. Trabalho de Conclusão do Curso de Mestrado Profissionalizante em Engenharia como requisito parcial à obtenção do título de Mestre em Engenharia.

DER (2008). Documento Técnico, Relatório de Avaliação Estrutural do Pavimento, km 142.000 ao km 173,820 da SP 253.

DER (2008). Documento Técnico, Relatório de Avaliação Funcional do Pavimento, km 142.000 ao km 173,820 da SP 253.

DNER (1994). Avaliação Objetiva da Superfície de Pavimentos Flexíveis e Semirrígidos - Procedimento Norma DNER-PRO 08 / 1994. Departamento Nacional de Infraestrutura de Transportes. Rio de Janeiro, RJ. 
DNER-M3 024/94 (1994). Pavimento - determinação das deflexões pela viga Benkelman - Método de Ensaio DNER.

DNIT (2003). Defeitos nos pavimentos flexíveis e semirrígidos - Terminologia NORMA DNIT 005 / 2003 - TER. Departamento Nacional de Infraestrutura de Transportes. Rio de Janeiro, RJ.

DNIT (2003) Avaliação objetiva da superfície de pavimentos flexíveis e semirrígidos - Procedimento NORMA DNIT 006 / 2003 - PRO. Departamento Nacional de Infraestrutura de Transportes. Rio de Janeiro, RJ.

DNIT (2003) Levantamento para avaliação da condição de superfície de subtrecho homogêneo de rodovias de pavimentos flexíveis e semirrígidos para gerência de pavimentos e estudos e projetos - Procedimento NORMA DNIT 007 / 2003 - PRO. Departamento Nacional de Infraestrutura de Transportes. Rio de Janeiro, RJ.

DNIT (2003) Levantamento visual contínuo para avaliação da superfície de pavimentos flexíveis e semirrígidos - Procedimento NORMA DNIT 008 / 2003 PRO. Departamento Nacional de Infraestrutura de Transportes. Rio de Janeiro, RJ.

DNIT (2003) Avaliação subjetiva da superfície de pavimentos flexíveis e semirrígidos - Procedimento NORMA DNIT 009 / 2003 - PRO. Departamento Nacional de Infraestrutura de Transportes. Rio de Janeiro, RJ.

DNIT (2006). Manual de Restauração de Pavimentos Rodoviários, Publicação IPR720, Ministério dos Transportes, DNIT.

DOMINGUES, F.A.A. (1993). MID - Manual para Identificação de Defeitos de Revestimentos Asfálticos de Pavimentos. São Paulo, S.P. 
FERNANDES JUNIOR, J.L.; ODA, S.; ZERBINI, L.F. (2003). Defeitos e Atividades de Manutenção e Reabilitação em Pavimentos Asfálticos, Universidade de São Paulo, Escola de Engenharia de São Carlos, Departamento de Transportes.

FHWA (1993) - U.S. Departament of Transportation. Distress Identification Manual for the Long-Term Pavement Performance Program. The Strategic Highway Research Program. National Academy of Science. Washington, D.C.

HAAS, R.; HUDSON, W.R.; ZANIEWSKY, J. (1994). Modern Pavement Management. Krieger Publishing Company, Malabar, Florida.

LABORATOIRE CENTRAL DES PONTS EL CHAUSSÉES, MÉTHODE D’ESSAI №52, COMPLÉMENTE À LA MÉTHODE D’ESSAI N³8-2 (1998). Catalogue de Dégradations de Surface des Chaussées. Techniques et méthodes des laboratoires des ponts et chaussées.

LOIOLA, P.R.R. (2009). Estudo de agregados e ligantes alternativos para emprego em tratamentos superficiais de rodovias. Dissertação de Mestrado. Universidade do Ceará, Programa de Mestrado em Engenharia de Transportes, Fortaleza.

LOPES, Simone Becker; PFAFFENBICHLER, Paul; EMBERGER, Gunter; RIEDL, Leopold (2008). Gerência de Pavimentos Urbanos com Uso de Modelagem Dinâmica de Sistemas Diretamente Conectada com um SIG. Panorama Nacional da Pesquisa em Transportes 2008 / XXII Congresso Nacional de Pesquisa e Ensino em Transportes. Fortaleza-CE, 03 a 07 de novembro de 2008.

MAGgIE COVALT, P.E. (2006). Washington State Airport Pavement Management System. Applied Pavement Technology. 
NAKAHARA, S.M. (2005). Estudo do Desempenho de Reforços de Pavimentos Asfálticos em Via Urbana Sujeita a Tráfego Comercial Pesado, Engenheira Civil, PUC / RS, Porto Alegre, Mestre em Engenharia Civil, UFRGS, Porto Alegre. Tese apresenta à Escola Politécnica da USP para obtenção do título de Doutor em Engenharia, Área de Concentração Engenharia de Transportes.

PRESTES, M.P. (2001). Métodos de Avaliação Visual de Pavimentos Flexíveis, Um Estudo Comparativo, Universidade Federal do Rio Grande do Sul, Escola de Engenharia, Mestrado Profissionalizante em Engenharia.

ROBERTS, F.L.; KANDHAL, P.S.; BROWN, E.R.; LEE, D.; KENNEDY, T.W. (1991). Hot Mix Asphalt Materials, Mixtures Design and Construction, First Edition, National Center for Asphalt Technology - Auburn University - Alabama, Dah-Yinn Lee - Iowa State University - Ames - Iowa, Thomas W. Kennedy University of Texas - Austin - Texas, NAPA Education Foundation, Lanham, Maryland.

SHAHIN, M.Y. (1994). Pavement Management for Airports, Roads and Parking Lots. Chapman\& Hall, New York.

THE AVIATION DIVISION FROM TEXAS DEPARTMENT OF TRANSPORTATION - TEXAS DOT (2000). Pavement Management Program for General Aviaton Airports. Austin, Texas. 


\section{ANEXOS}

- Tabelas retiradas das Normas Brasileiras:

ANEXO 1 - Classificação dos Defeitos - Norma DNIT 005/2003-TER.

ANEXO 2 - Fatores de Ponderação e Conceitos de degradação do pavimento em função do IGG - Norma DNIT 006/2003-PRO 108

ANEXO 3 - Gravidades e Frequências, Pesos para cálculo, Conceitos ICPF e Descrições - Norma DNIT 008/2003-PRO .109

- Tabelas retiradas do Método Vizir utilizado na França:

ANEXO 4 - Determinação de IF, ID, correção por Reparação - Método VIZIR.......110 


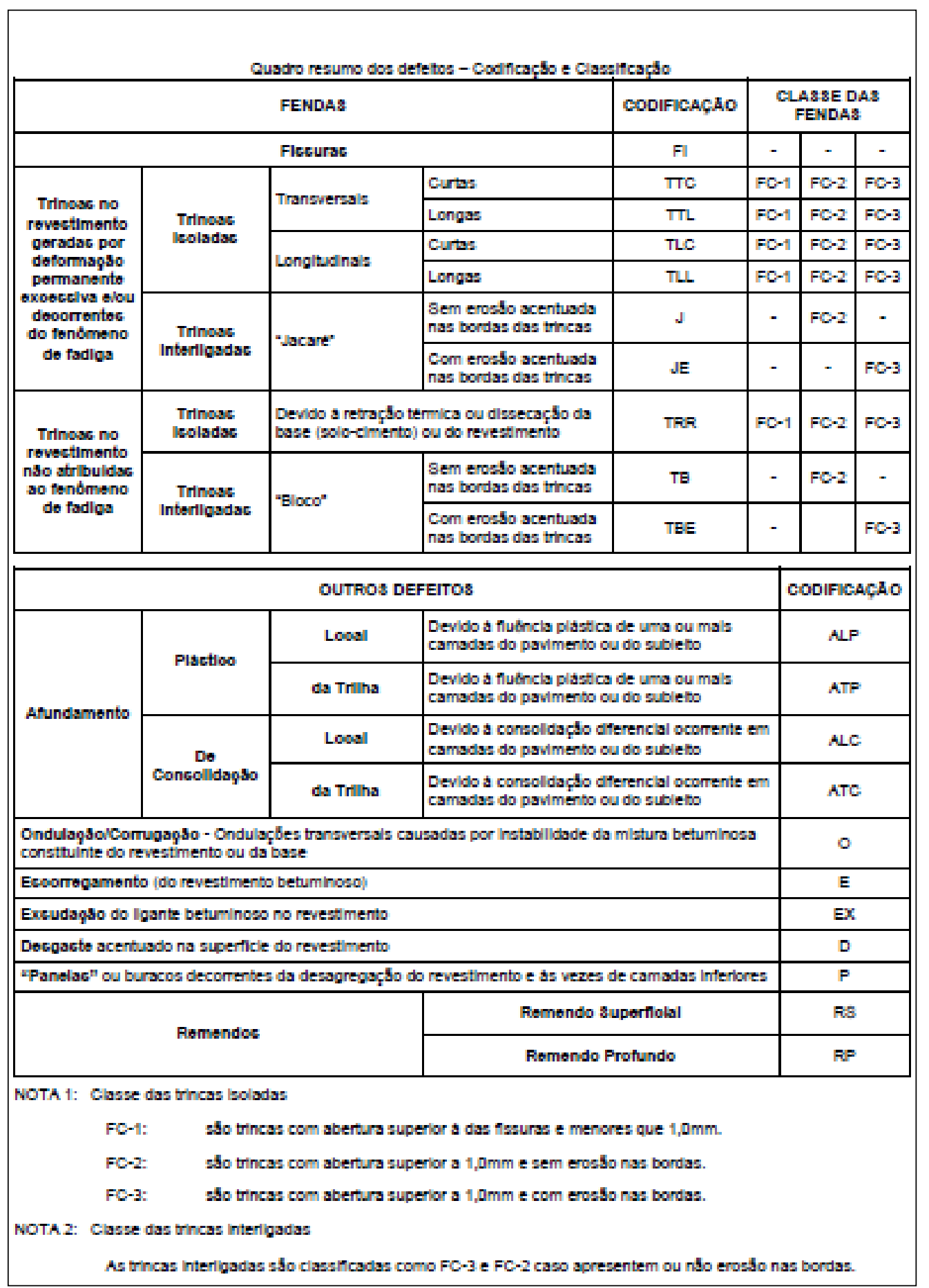

ANEXO 1 - Classificação dos Defeitos

Norma DNIT 005/2003-TER 


\begin{tabular}{|c|c|c|c|c|}
\hline \multicolumn{5}{|c|}{ Valor do Fator de Ponderação } \\
\hline $\begin{array}{l}\text { Ocorrência } \\
\text { Tipo }\end{array}$ & \multicolumn{3}{|c|}{$\begin{array}{l}\text { Codificação de ocorrências de acordo com a Norma DNIT 005/2002-TER "Defeitos nos } \\
\text { pavimentos flexíveis e semi-rigidos - Terminologia" (ver item 6.4 e Anexo D) }\end{array}$} & $\begin{array}{l}\text { Fator de } \\
\text { Ponderaçäo } \\
\text { fp }\end{array}$ \\
\hline 1 & \multicolumn{3}{|c|}{ Fissuras e Trincas Isoladas (FI, TTC, TTL, TLC, TLL e TRR) } & 0,2 \\
\hline 2 & \multicolumn{3}{|c|}{ FC-2 ( $\mathrm{J}$ e TB) } & 0,5 \\
\hline 3 & \multicolumn{3}{|c|}{$\begin{array}{l}\text { NOTA:Para efeito de ponderação quando em uma mesma estação forem constatadas } \\
\text { ocorréncias tipos } 1,2 \text { e } 3 \text {, só considerar as do tipo } 3 \text { para o cálculo da frequêencia relativa em } \\
\text { percentagem (fr) e Indice de Gravidade Individual (IGI); do mesmo modo, quando forem } \\
\text { verificadas ocorrências tipos } 1 \text { e } 2 \text { em uma mesma estação, só considerar as do tipo } 2 \text {. }\end{array}$} & 0,8 \\
\hline 4 & \multicolumn{3}{|c|}{ ALP, ATP e ALC, ATC } & 0,8 \\
\hline 5 & \multicolumn{3}{|l|}{ O, P.E } & 1,0 \\
\hline 6 & \multicolumn{3}{|l|}{ EX } & 0,5 \\
\hline 7 & \multicolumn{3}{|l|}{ D } & 0,3 \\
\hline 8 & \multicolumn{3}{|l|}{$R$} & 0,6 \\
\hline \multicolumn{5}{|c|}{ Índice de gravidade global (IGG) } \\
\hline \multicolumn{5}{|c|}{ O Indice de Gravidade Global (IGG) é obtido por meio } \\
\hline \multirow{2}{*}{\multicolumn{2}{|c|}{$I G G=\sum I G I$}} & Otimo & \multicolumn{2}{|c|}{$0<1 G G \leq 20$} \\
\hline & & Bom & \multicolumn{2}{|c|}{$20<I G G \leq 40$} \\
\hline & Regular & \multicolumn{2}{|c|}{$40<$ IGG $\leq 80$} \\
\hline \multirow{2}{*}{\multicolumn{2}{|c|}{$\begin{array}{l}\text { E IGI - somatório dos Indices de Gravidade Individuais, } \\
\text { calculados de acordo com o estabelecido no item 7.3. }\end{array}$}} & Ruim & \multicolumn{2}{|c|}{$80<I G G \leq 160$} \\
\hline & & Péssimo & \multicolumn{2}{|c|}{ IGG $>160$} \\
\hline \multicolumn{2}{|c|}{$\begin{array}{l}\text { calculados de acordo com o estabelecido no item } 7.3 .0 \\
\text { Indice de Gravidade Global deve ser calculado para } \\
\text { cada trecho homogêneo (ver Anexo } \mathrm{C} \text { ). }\end{array}$} & & & \\
\hline \multicolumn{5}{|c|}{ Conceito de degradação do pavimento } \\
\hline $\begin{array}{l}\text { Com a finalid: } \\
\text { um conceito o } \\
\text { é definida a co } \\
\text { seguir: }\end{array}$ & $\begin{array}{l}\text { ade de conferir ao pavimento inventariado } \\
\text { que retrate o grau de degradação atingido, } \\
\text { orrespondência apresentada na Tabela } 2 \text { a }\end{array}$ & & & \\
\hline
\end{tabular}

ANEXO 2 - Fatores de Ponderação e Conceitos de degradação do pavimento em função do IGG - Norma DNIT 006/2003-PRO 


\begin{tabular}{|c|c|c|}
\hline CONCEITO & DESCRIÇÃO & ICPF \\
\hline Ótimo & $\begin{array}{l}\text { NECESSITA APENAS DE } \\
\text { CONSERVAÇÂOO } \\
\text { ROTINEIRA }\end{array}$ & $5-4$ \\
\hline Bom & $\begin{array}{l}\text { APLICAÇÃO DE LAMA } \\
\text { ASFÁLTICA - Desgaste } \\
\text { superficial, trincas não } \\
\text { muito severas em áreas } \\
\text { não muito extensas }\end{array}$ & $4-3$ \\
\hline Regular & $\begin{array}{l}\text { CORREÇÃO DE PONTOS } \\
\text { LOCALIZAADOS OU } \\
\text { RECAPEAMENTO - } \\
\text { pavimento trincado, com } \\
\text { "panelas" e remendos } \\
\text { pouco freqüentes e com } \\
\text { irregularidade longitudinal } \\
\text { ou transversal. }\end{array}$ & $3-2$ \\
\hline Ruim & $\begin{array}{l}\text { RECAPEAMENTO COM } \\
\text { CORREÇÕES PRÉVIAS - } \\
\text { defeitos generalizados com } \\
\text { correções prévias em } \\
\text { áreas localizadas - } \\
\text { remendos superficiais ou } \\
\text { profundos. }\end{array}$ & $2-1$ \\
\hline Péssimo & $\begin{array}{l}\text { RECONSTRUÇÃO - } \\
\text { defeitos generalizados com } \\
\text { correções prévias em toda } \\
\text { a extensão. Degradação do } \\
\text { revestimento e das demais } \\
\text { camadas - infiltração de } \\
\text { água e descompactação da } \\
\text { base }\end{array}$ & $1-0$ \\
\hline
\end{tabular}

\begin{tabular}{|c|c|c|}
\hline \multicolumn{3}{|c|}{ Panelas (P) e Remendos (R) } \\
\hline FREQÜÊNCIA & $\begin{array}{c}\text { Fator Fpr } \\
\text { Quantidade/Km }\end{array}$ & GRAVIDADE \\
\hline A - ALTA & $\geq 5$ & 3 \\
\hline M - MÉDIA & $2-5$ & 2 \\
\hline B - BAIXA & $\leq 2$ & 1 \\
\hline \multicolumn{3}{|c|}{ Demais defeitos (trincas, deformações) } \\
\hline FREQÜÊNCIA & $\begin{array}{l}\text { Fatores Ft e Foap } \\
\qquad(\%)\end{array}$ & GRAVIDADE \\
\hline A - ALTA & $\geq 50$ & 3 \\
\hline M - MÉDIA & $50-10$ & 2 \\
\hline B - BAIXA & $\leq 10$ & 1 \\
\hline
\end{tabular}

Pesos para cálculo

\begin{tabular}{|c|c|c|c|}
\hline GRAVIDADE & Pt & Poap & Ppr \\
\hline 3 & 0,65 & 1,00 & 1,00 \\
2 & 0,45 & 0,70 & 0,80 \\
1 & 0,30 & 0,60 & 0,70 \\
\hline
\end{tabular}

Frequiência de defeitos

\begin{tabular}{|c|c|c|}
\hline \multicolumn{3}{|c|}{ Panelas (P) e Remendos (R) } \\
\hline Código & Frequiência & Quant./km \\
\hline A & Alta & $\geq 5$ \\
\hline M & Média & $2-5$ \\
\hline B & Baixa & $\leq 2$ \\
\hline \multicolumn{3}{|c|}{ Demais defeitos } \\
\hline Código & Frequiência & $\%$ por km \\
\hline A & Alta & $\geq 50$ \\
\hline M & Média & $50-10$ \\
\hline B & Baixa & $\leq 10$ \\
\hline
\end{tabular}

ANEXO 3 - Gravidades e Frequências, Pesos para cálculo, Conceitos ICPF e Descrições - Norma DNIT 008/2003-PRO 


\section{DETERMINAÇÃO DO ÍNDICE DE DEGRADAÇÃO}

\begin{tabular}{|l|l|} 
Se não tiver fissura nem deformação & 0 \\
\hline
\end{tabular}

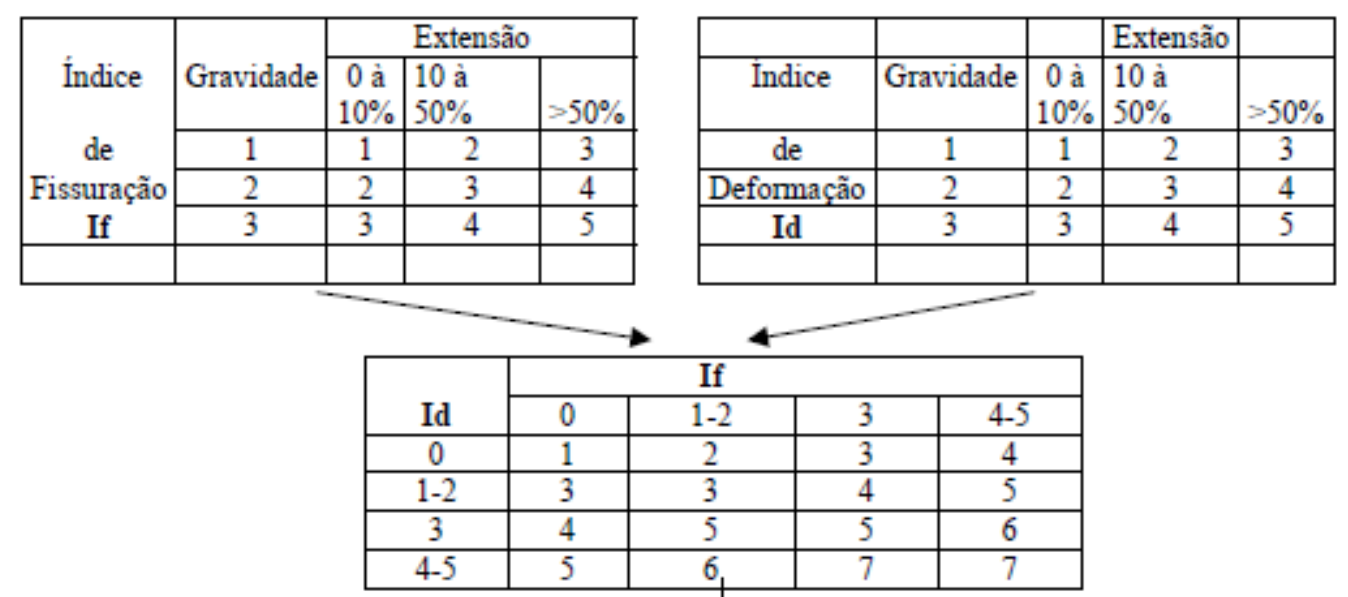

\begin{tabular}{|c|c|c|c|}
\hline \multirow{3}{*}{ Gravidade } & \multicolumn{3}{|c|}{ Extensão } \\
\cline { 2 - 4 } & 0 à & 10 à & \\
& $10 \%$ & $50 \%$ & $>50 \%$ \\
\hline 1 & 0 & 0 & 0 \\
\hline 2 & 0 & 0 & +1 \\
\hline 3 & 0 & +1 & +1 \\
\hline
\end{tabular}

Conreção por reparação

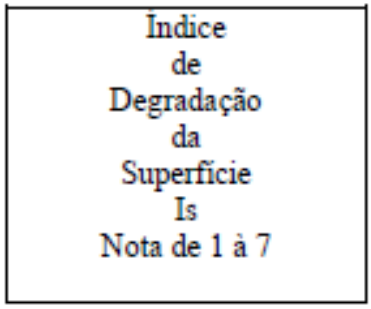

ANEXO 4 - Determinação de IF, ID, correção por Reparação

Método VIZIR 